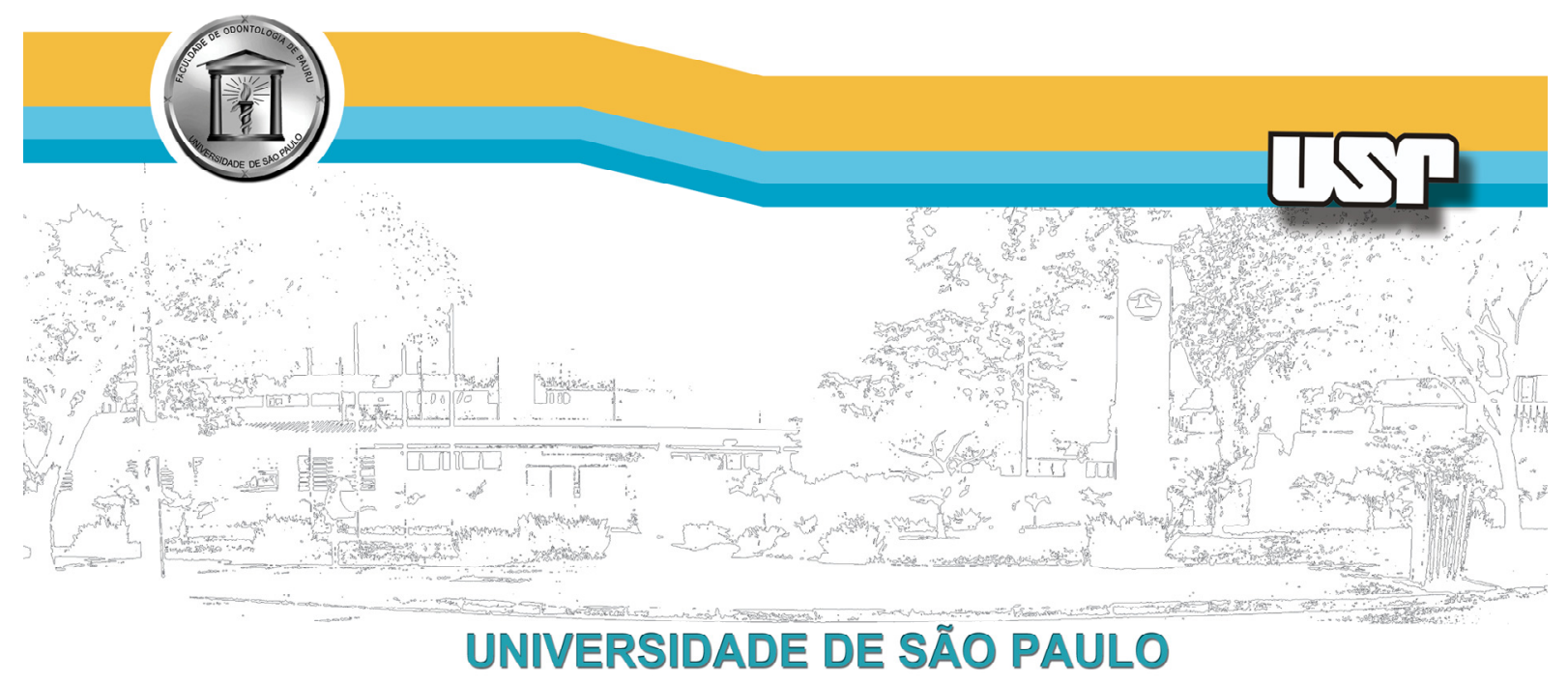

Faculdade de Odontologia de Bauru

VANESSA TESSAROLLI

\title{
Ação da Terapia Fotodinâmica (TFD) sobre biofilme dentário humano
}


Dissertação apresentada a Faculdade de Odontologia de Bauru da Universidade de São Paulo para obtenção do título de Mestre em Ciências Odontológicas Aplicadas.

Área de concentração: Odontopediatria Orientador: Prof ${ }^{a}$. Dra. Maria Aparecida de Andrade Moreira Machado. 
Tessarolli, Vanessa

T284 Ação da Terapia Fotodinâmica sobre biofilme

a dentário humano / Vanessa Tessarolli. - Bauru, 2010.

131 p. : il. ; $30 \mathrm{~cm}$.

Dissertação (Mestrado) - Faculdade de

Odontologia de Bauru. Universidade de São Paulo

Orientador: Prof ${ }^{a}$. Dra. Maria Aparecida de Andrade Moreira Machado

Autorizo, exclusivamente para fins acadêmicos e científicos, a reprodução total ou parcial desta dissertação/tese, por processos fotocopiadores e outros meios eletrônicos.

Assinatura:

Data:

Comitê de Ética da FOB-USP

Protocolo no: $144 / 2008$

Data: 24/06/2009 
ERRATA 
(Cole a cópia de sua folha de aprovação aqui) 


\section{DADOS CURRICULARES}

\section{Vanessa Tessarolei}

Nascimento

Naturalidade

Filiação

2004-2007

2008-2008

$2009-2010$
27 de Janeiro de 1986

Bariri - São Paulo

Paulo Roberto Tessarolli

Silvana Regina Pascholatti Tessarolli

Curso de Graduação em Odontologia pela Faculdade de Odontologia de Bauru da Universidade de São Paulo - FOB-USP

Prática Profissionalizante em Odontopediatria pela Faculdade de Odontologia de Bauru da Universidade de São Paulo - FOB-USP

Curso de Pós-Graduação em Ciências Odontológicas Aplicadas, área de Odontopediatria, em nível de Mestrado, pela Faculdade de Odontologia de Bauru da Universidade de são Paulo - FOB-USP 


\section{DEDICATÓRIA}

Dedico este trabalho...

\section{... à DEUS,}

que é AMOR acima de tudo! Que me trata como filha, iluminando meu caminho! Que está sempre presente me ajudando, me dando esperanças! Que permite que eu ultrapasse os inúmeros obstáculos da vida! Que me presenteou com uma vida feliz, ao lado de uma maravilhosa família e muitos amigos! Que me permite acordar todos os dias e realmente viver! Sem Ele nada seria possível! Enquanto tiver fé, sei que não caminharei sozinha! Obrigada, Senhor! 


\section{AGRADECIMENTOS}

\section{"Tu te tornas eternamente responsável por aquillo que cativas."}

(Saint Exupery)

À minha família...

Aos meus pais Silvana e Tessa e ao meu irmão Junior, por fazerem parte da minha vida. Por terem me educado, por possibilitarem que eu crescesse num ambiente saudável, com muito carinho, felicidade e, principalmente, AMOR. Por estarem sempre presentes em todos os momentos, aconselhando, incentivando, elogiando e dando forças. Obrigada por possibilitarem que eu chegasse até aqui. Sem vocês, nada seria possível. Vocês fazem parte de todas as minhas conquistas! Sem vocês nada seria possível Amo muito vocês!

Por todos os meus familiares: Vó Iracema, Vô Adelino,Vô Osmar, vó Terezinha (em memória), Bisa Helena, todos os tios, tias e primos, obrigada pelo apoio e carinho.

Ao Paulinho, meu namorado, que em tão pouco tempo já se tornou uma pessoa muito especial em minha vida. Obrigada por todo incentivo, força e carinho!

\section{"A tarefa essencial do professor é despertar a aleqria de trabalhar e de conhecer."}

(Albert Eisntein)

À minha orientadora Prof. ${ }^{a}$ Cidinha. Obrigada pelo exemplo de professora e orientadora. Obrigada por me ensinar a ver as situações de forma positiva, sempre acreditando que é possível de se realizar as coisas desde que se queira. Obrigada pelos inúmeros pensamentos, idéias (quase sempre visionárias) que sempre 
enriqueceram meus conhecimentos e me instigaram a ser um pouquinho mais cientista! Obrigada pelas críticas que me fizeram crescer e amadurecer e pela confiança depositada na realização das atividades. Obrigada pela determinação, que sempre me estimulou a buscar novos conhecimentos e explicações para as situações. Obrigada por ter aceitado me orientar, mesmo diante de uma agenda repleta de compromissos importantes. Obrigada por estar sempre disposta a, ser uma verdadeira amiga durante esses anos de convivência, por todo o crescimento profissional e pessoal e pela motivação constante. Saiba que sou uma grande admiradora desse seu jeito especial de ver o mundo e de fazer a diferença nele. Obrigada por tudo. Espero ter correspondido às suas expectativas.

À Profa. Dra. Ana Paula Campanelli. Obrigada por ter me apresentado à pesquisa, por ter me acolhido no laboratório desde o primeiro ano de faculdade. Obrigada pelo seu grande conhecimento nos assuntos laboratoriais e pelos inúmeros ensinamentos, sem você a realização dessa dissertação não seria possível. Obrigada por sempre me atender e me ajudar com muito carinho!

À Professora Salete, coordenadora do curso de Mestrado em Odontopediatria. Obrigada por todos os ensinamentos de como ser uma boa Odontopediatra. Obrigada por estar sempre disposta a solucionar questões clínicodidáticas. Obrigada pelo exemplo de professora universitária.

À Professora Thais, por todos os ensinamentos e incentivos, sempre dando forças. Obrigada por estar sempre disposta a ajudar e aconselhar. Obrigada por ter sido uma amiga verdadeira. Saiba que a admiro muito e tenho certeza do seu grande sucesso nessa carreira de professora que está apenas começando.

À Professora Daniela, obrigada pelo seu imenso conhecimento em pesquisas, ajudando na elaboração do meu projeto. Obrigada pelo exemplo de dedicação em pesquisa e em ser professora. Obrigada por todos os conselhos.

Ao Professor Ruy, que foi o primeiro a me apresentar a Odontopediatria clínica, sendo assim também responsável pela minha paixão na especialidade. 
Obrigada pelo exemplo de vida e pelos inúmeros ensinamentos, que somente poderiam vir de alguém tão experiente e de sucesso na vida.

Ao Professor José Eduardo, por uma boa convivência nas clínicas, pelos ensinamentos clínicos valiosos, também de alguém extremamente experiente na Odontopediatria.

Aos funcionários do Departamento de Odontopediatria: Lilian, Estela, D. Lia, Alexandre, Fátima. Obrigada pela companhia quase diária, por estarem sempre dispostos a ajudar. Obrigada por me acolher de braços abertos e nunca negar qualquer tipo de contribuição.

Ao técnico de laboratório André. Sem ele essa pesquisa não seria possível. Sempre dando um jeitinho de preparar meus meios de cultura, conseguindo os materiais que faltavam. Possibilitando assim, sem medir esforços, o sucesso dos experimentos. Acima de tudo, obrigada pela amizade e pela convivência agradável no laboratório.

À Thais, pós-doutoranda do laboratório de Microbiologia. Obrigada por todos os ensinamentos desde minha iniciação científica. Obrigada por estar sempre disposta a me ajudar, sem medir esforços. Obrigada também pela amizade!

À Márcia Graeff que foi responsável pela obtenção das imagens em microscopia confocal. Obrigada pela atenção sempre carinhosa, por transmitir seus conhecimentos valiosos. Obrigada pela disponibilidade e pela amizade.

Aos funcionários do Departamento de Microbiologia: Dalva e Livia. Obrigada por todo o tipo de ajuda.

Ao Thiago Dionisio, com seu imenso conhecimento, sempre esteve disposto ajudar, a me dar informações sobre a FAPESP e principalmente me dar forças. Torço muito por você. 
Às Professora Vanessa e Marília que possibilitaram que eu usasse os laboratórios de Patologia e Bioquímica sem objeção. Obrigada pelos conhecimentos transmitidos

\section{“Mesmo que as pessoas mudem e swas vidas se reorganizem, os amigos deverm ser amigos para sempre, mesmo que mâo tenham nada erm comum, somente compartillhar as mesmas recordaçôes."}

(Vinícius de Moraes)

Às colegas de Mestrado: Annelyze, Flavia, Maísa, Janaína, Aninha. Obrigada por tudo o que passamos juntas. Obrigada por estarmos sempre unidas, ultrapassando os inúmeros obstáculos do nosso curso. Obrigada por alegrarem nossas atividades. Acima de tudo, obrigada pela amizade e companheirismo.

Aos colegas de Doutorado: Adriana, Juliana, Ana Lídia, Carla, Natal, Taty, Akio. Obrigada pelos conhecimentos transmitidos e pela amizade.

Aos colegas de laboratório: Carine, Michele, Eduardo, Hayana, Lucas, Claudinha, Carla, Carol. Obrigada pela convivência, amizade e ensinamentos.

Aos meus colegas da turma XLIII, que continuaram a fazer a parte da minha vida: Bruna, Carol, Monica, Kellen, Hugo, Thais. Obrigada pela amizade e pelos momentos de alegria.

Aos meus amigos de Bariri, pela amizade não perdida mesmo morando fora, por me agüentarem falar de experimentos, de artigos, de pacientes em vários fins de semana, sempre compreendendo e dando forças. Em especial: Li, Laurinha, Cris, Vanessa, Helton, Reginaldo, Elcio, Fernando!!! 
(Francis Bacon)

À Faculdade de Odontologia de Bauru, no nome do Diretor José Carlos Pereira, obrigado por ter me propiciado cursar graduação Odontologia num curso exemplar, propiciando-me uma excelente formação e pós-graduação a nível de Mestrado em Odontopediatria.

À Fapesp, pelo apoio financeiro na execução desse projeto.

Enfim, agradeço a todos que de alguma forma

auxiliaram na realização desse projeto ou fizeram parte da minha vida nesta fase:

Muito obrigada por tornarem a realinação desse sonho possivel... 
O ADOLESCENTE

“A vida é tão bela que chega a dar medo.

Não o medo que paralisa e gela, estátua súbita,

mas

esse medo fascinante e fremente de curiosidade que faz

- jovem felino seguir para a frente farejando o vento ao sair, a primeira vez, da gruta.

Medo que ofusca: Luz!

Eumplicemente, as folhas contam-te um segredo velho como o mundo:

Adolescente, olha! At vida é nova...

At vida é nova e anda nua - vestida apenas com o teu desejo!

MARIO QUINTANA 


\section{RESUMO}

Entre os métodos de prevenção da cárie dentária, os controles mecânico e químico do biofilme dentário são de grande relevância neste processo. O controle mecânico é eficaz desde que executado diariamente e sistematicamente envolver todas as superfícies dentárias expostas ao meio bucal. Ele pode ser realizado pelo odontólogo por meio da profilaxia profissional e pelo próprio paciente pela escovação dentária. O controle químico do biofilme dentário deve ser empregado de forma suplementar, quando o controle mecânico não puder ser realizado diariamente ou se for realizado de forma inadequada acarretando o risco do acúmulo do biofilme dentário e como consequência, a ocorrência de lesões de cárie dentária e/ou da doença periodontal. $O$ ideal seria associar ambos os métodos, para que um compense a deficiência do outro. É nesta direção que inúmeros estudos são feitos nos últimos anos.

Para o controle químico, são relatadas na literatura inúmeras substâncias antimicrobianas. Dentre os agentes químicos recomendados, a clorexidina (CLX) tem se mostrado eficiente para esta finalidade, porém, sua aplicação apresenta limitações como: manchamento de áreas desmineralizadas dos dentes e perda do paladar, condições estas que limitam seu uso por tempo prolongado. Sendo assim, a busca de alternativas para o controle microbiano do biofilme dentário é de grande relevância para se somar aos esforços ora empreendidos neste sentido. Nas últimas décadas o emprego da luz associada a corantes surgiu como um tratamento alternativo ao uso de agentes antimicrobianos tradicionais. Este tratamento é chamado terapia fotodinâmica (TFD), sendo recentemente também chamado de Terapia Fotodinâmica Antimicrobiana (TFDA). Na TFDA, a luz interage com o corante que está associado ao microorganismo, sendo capaz de inibir sua proliferação ou eliminá-lo completamente. Poucos são os estudos que avaliam a ação antimicrobiana da TFD sobre biofilmes cariogênicos. A comprovação da eficácia dessa terapia sobre o biofilme dentário humano poderá ter um impacto positivo para a Odontologia, favorecendo a implantação de novos protocolos de controle químico do mesmo. Este estudo teve como objetivo analisar comparativamente o efeito da clorexidina e da TFDA (com dois tipos de 
fotossensibilizadores: Azul de Toluidina $\mathrm{O}$ (TBO) e Clorofila Líquida (CL)) sobre biofilmes dentários humanos formados in situ. Voluntários utilizaram um dispositivo intrapalatino contendo espécimes de esmalte dental, sobre os quais biofilme dentário foi formado. Após 48 horas, diferentes terapias foram aplicadas sobre o biofilme: (1) água destilada: controle negativo; (2)CLX; (3) irradiação por laser; (4) TBO; (5) TBO +laser; (6) $\mathrm{CL}$; (7) $\mathrm{CL}$ + laser. O biofilme então foi coletado e solubilizado. Em seguida, amostras foram semeadas em placas de Petri com diferentes meios de cultura, para contagem do número de microrganismos totais, estreptococos totais, Streptococcos mutans, Lactobacilos e Candida albicans. Amostras também foram coradas com Laranja de Acridina e visualizadas em microscopia de fluorescência, para análise da viabilidade das células presentes. Os resultados dos plaqueamentos apenas nos deram informações sobre os microrganismos totais e estreptococos totais, mostrando que a única redução significante dos microorganismos em relação ao grupo (1) ocorreu no grupo tratado por CLX (2). As outras terapias mostraram uma sensível redução. A viabilidade por microscopia por fluorescência se mostrou semelhante em todos os grupos. A clorexidina, portanto, comprovou seu efeito antimicrobiano, porém mais estudos precisam ser realizados para verificar o real papel da TFD sobre biofilme dentário humano.

Palavras-chave: Terapia Fotodinâmica. Placa Dentária. Clorexidina. 


\section{ABSTRACT}

\section{THE ACTION OF PHOTODYNAMIC THERAPY ON HUMAN DENTAL PLAQUE}

The mechanical and chemical controls of dental plaque are important methods of caries prevention. The mechanical control is efficient if it's run properly and daily. It can be made by a dentist (professional cleaning) or by patients themselves (toothbrushing). The chemical control should be used additionally, when the mechanical control can't be performed properly, them the biofilm can accumulate and in consequence, there are risks of dental caries or periodontal disease. For chemical control, many antimicrobial substances are related in literature. Several studies have shown that chlorexidine (CLX) is an effective antimicrobial substance against dental plaque. However, it presents some limitations like: tooth staining, loss of taste, conditions that limit its use by prolonged periods. Therefore, the search by new alternatives in microbial control of plaque is very important for improvement the treatment. In last decades, the use of light for activation of a photosensitizer appears like an alternative treatment with antimicrobial function. This treatment is called Photodynamic Therapy (PDT), recently Photochemotherapy (PACT). In PACT, the light activates a photosensitizer that is bond in microorganism and it can kill it or inhibit its growing. If this treatment is effective on human dental plaque, it will have positive impact for Dentistry and new protocols of chemical control will be developed. The present study aim was analyze the chlorexidine effect and the PDT effect (using Toluidine blue (TBO) and Liquid Chlorophyll (LC) like photosensitizer) in human natural dental plaque formed in situ. Volunteers wore a palatal appliance containing bovine enamel blocks, where the biofilm was formed. After 48 hours, different therapies were performed on plaque: (1) distilled water: negative control; (2) CLX; (3) Laser irradiation; (4) TBO; (5) TBO + Laser; (6) CL; (7) CL + Laser. The plaque samples were collected and dispersed. Next, serial dilutions were prepared and seeded onto different culture broth for the determination of the number of colonyforming units per gram (CFU/g) of total microorganisms, total Streptococcus, Streptococcus mutans, Lactobacillus and C. albicans. Samples were stained with acridine orange to analyze cells viability. The results can reveal only information 
about total microorganism and total Streptococcus. When the groups (2-7) were compared with the group (1), significant microbial reduction was observed only in group treated with CLX (3). The other therapies showed only a discrete reduction in relation of group (1). The cell viability showed similar results in all groups. Therefore, the CLX proved its antimicrobial effect. More studies are necessary for exact evaluation of effect of TFD on dental plaque human.

Key words: Photochemotherapy. Dental Plaque. Chlorhexidine. 


\section{LISTA DE ILUSTRAÇÕES}

\section{- FIGURAS}

Figura 1 - Obtenção dos espécimes bovines..................................... 35

Figura 2 - Máquina de corte e fragmento seccionado.................................... 35

Figura 3 - Politriz metalográfica.............................................................. 36

Figura 4 - Dispositivo intrapalatino..................................................... 37

Figura 5 - LASER HAND ${ }^{\circledR}, 660$ WL, MM Optics Ltda............................ 39

Figura 6 - Plaqueamento de amostras dos oito grupos de um paciente em meio $\mathrm{BHI}$, na diluição $10^{4}$, após $48 \mathrm{~h}$ em estufa a $37^{\circ} \mathrm{C}$.................. 44

Figura 7 - Plaqueamento de amostras dos oito grupos de um paciente em meio Agar MS, na diluição $10^{3}$, após $48 \mathrm{~h}$ em estufa a $37^{\circ} \mathrm{C} \ldots \ldots \ldots . . . \quad 47$

Figura 8- Plaqueamento de amostras dos oito grupo em meio SB20 acrescido de Bacitracina, na diluição $10^{1}$, após $72 \mathrm{~h}$ em câmara de microaerofilia e em estufa a $37^{\circ} \mathrm{C}$......................................... 50

Figura 9 - Plaqueamento de amostras dos oito grupo em meio Agar Rogosa, sem diluição, após $72 \mathrm{~h}$ em câmara de microaerofilia e

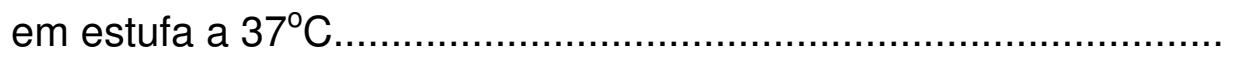

Figura 10- Plaqueamento de amostras dos oito grupos no paciente em que houve crescimento, em meio Agar Sabauraud, sem diluição, após

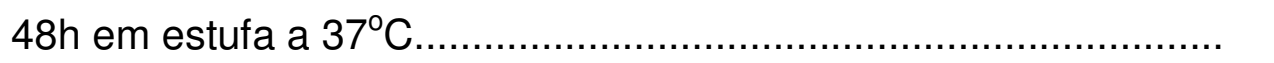

Figura 11- Imagens obtidas por microscopia de fluorescência após amostras serem coradas por laranja de acridina...... 


\section{- GRÁFICOS}

Gráfico 1 - Contagem dos microorganismos totais (UFC por grama de biofilme) após plaqueamento e incubação por 48 horas...

Gráfico 2 - Redução dos microorganismos totais (\%) em relação ao grupo controle negativo, após plaqueamento e incubação por 48horas....

Gráfico 3 - Contagem dos Estreptococos totais (UFC por grama de biofilme) após plaqueamento e incubação por 48horas

Gráfico 4 - Redução dos microorganismos totais (\%) em relação ao grupo controle negativo, após plaqueamento e incubação por 48horas.... 49

Gráfico 5 - Porcentagem de células consideradas viáveis nas imagens 52 obtidas por microscopia. 


\section{LISTA DE TABELAS}

Tabela 1 - Contagem dos microorganismos totais (UFC por grama de biofilme) \pm desvio padrão, após plaqueamento e incubação por 48horas

Tabela 2 - Redução dos microorganismos totais (\%) em relação ao grupo controle negativo, após plaqueamento e incubação por 48horas......

Tabela 3 - Contagem dos Estreptococos totais (UFC por grama de biofilme) 45 após plaqueamento e incubação por 48horas................................. 47

Tabela 4 - Redução dos Estreptococos totais (\%) em relação ao grupo controle negativo, após plaqueamento e incubação por 48horas...... 48

Tabela 5 - Média \pm desvio padrão da porcentagem de células consideradas inviáveis nas fotos obtidas por microscopia de fluorescência............ 52 


\title{
LISTA DE ABREVIATURA E SIGLAS
}

\author{
TFD Terapia Fotodinâmica \\ CLX Clorexidina \\ TBO Azul de Toluidina $O$ \\ CL Clorofila Líquida \\ ALA Ácido aminolevulínico \\ He-Ne Hélio-Neônio \\ In-Ga-Al-P Fosfeto Indio-Gálio-Alumínio \\ GaALAs Arseneto Gálio Alumínio \\ $\mathrm{mW} \quad$ Miliwatts \\ $\mathrm{PPArg}_{2} \quad$ Protoporfirina com duas moléculas de Arginato \\ TFAP $^{3+} \quad$ 5-(4-trifluorophenyl)-10,15,20-tris(4-trimethylammoniumphenyl) \\ porphyrin iodide \\ TMAP $^{4+} \quad 5,10,15,20$-tetra(4-N,N,N-trimethylammonium phenyl) porphyrin $p$ - \\ tosylate \\ TPPS $^{4+} \quad$ 5,10,15,20-tetra(4-sulphonatophenyl)porphyrin \\ S. mutans Streptococcus mutans \\ S. sobrinus Streptococcus sobrinus \\ S. aureus Staphylococcus aureus \\ S. sanguis Streptococcus sanguis \\ S.sanguinis Streptococcus sanguinis \\ S. oralis Streptococcus oralis \\ S. mitis Streptococcus mitis \\ E. coli Escherichia coli \\ UFC Unidades formadoras de colônia \\ g grama \\ LED Diodo Emissor de Luz \\ $\mathrm{J} / \mathrm{cm}^{2} \quad$ Joule por centímetro quadrado \\ $\mu \mathrm{m} \quad$ micrometro
}


C. albicans Candida albicans

$\begin{array}{ll}\mathrm{Pg} & \text { Porphyromonas gingivalis } \\ \mathrm{Aa} & \text { Aggregatibacter actinomycetemcomitans } \\ \text { C. glabrata } & \text { Candida glabrata } \\ \text { PBS } & \text { Phosphate Buffered Saline } \\ \mathrm{BHI} & \text { Agar Brain Heart Infusion } \\ \mathrm{MS} & \text { Ágar Mitis Salivarius } \\ \mathrm{Mg} & \text { Magnésio }\end{array}$




\section{SUMÁRIO}

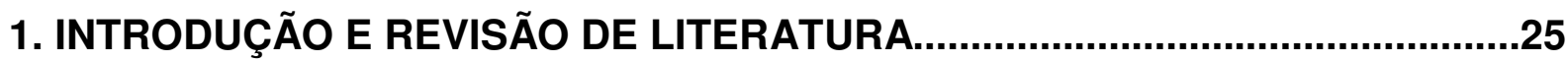

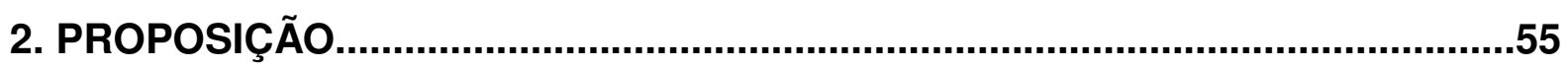

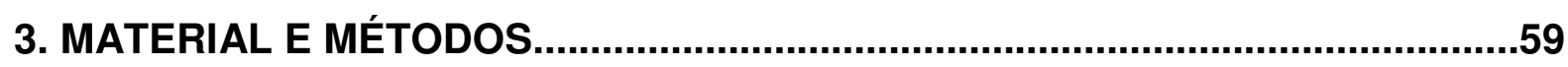

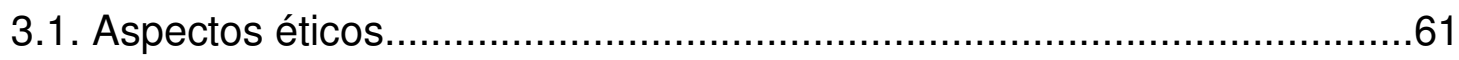

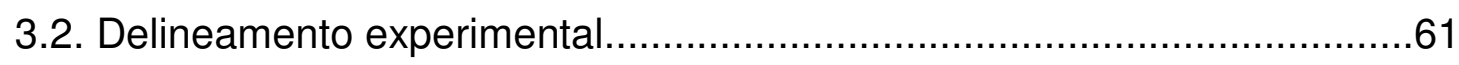

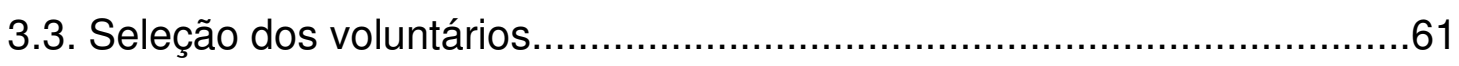

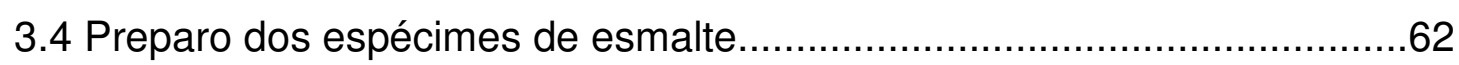

3.4.1. Obtenção de dentes bovinos...................................................

3.4.2. Obtenção dos espécimes de esmalte bovino.............................62

3.4.3. Planificação e polimento dos espécimes de esmalte....................63

3.5. Preparo do dispositivo intrabucal palatino.............................................64

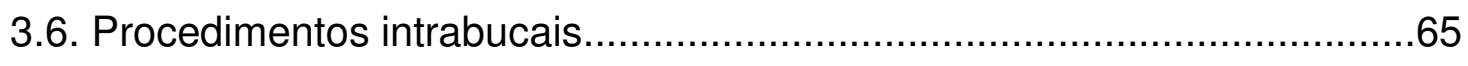

3.7. Terapias aplicadas aos espécimes...................................................65

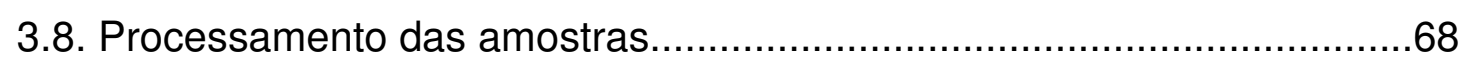

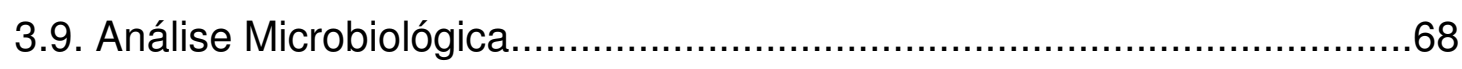

3.10. Microscopia de Fluorescência

3.10.1. Processamento das amostras para microscopia......................69

3.10.2. Análise em Microscopia de Fluorescência................................69

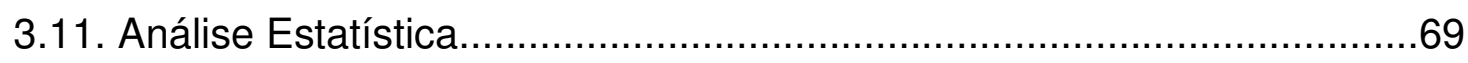

\section{RESULTADOS}

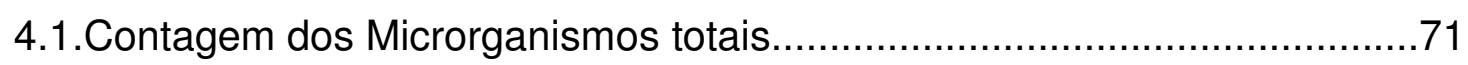

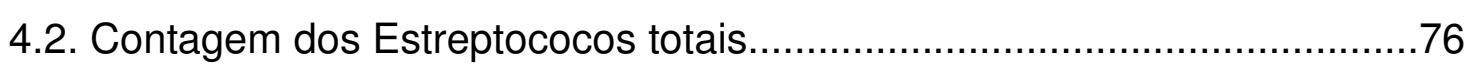

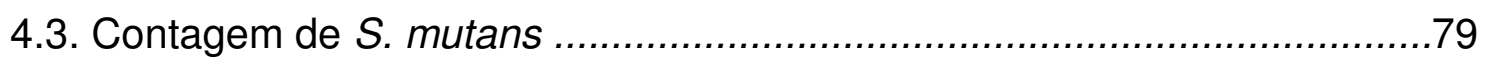

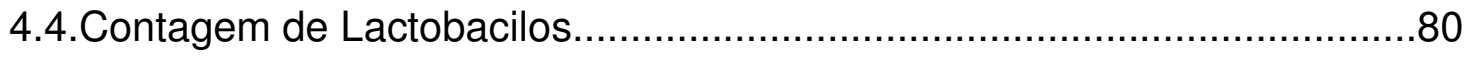

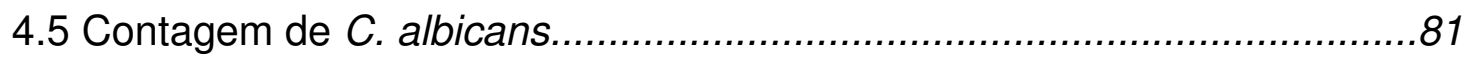

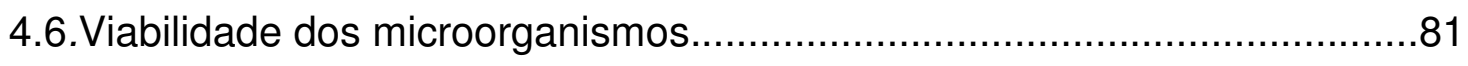

5.DISCUSSÃO

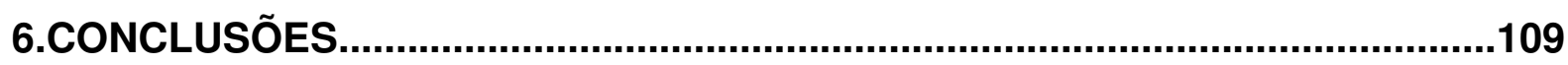

REFERÊNCIAS.......................................................................................113 
ANEXOS.

129

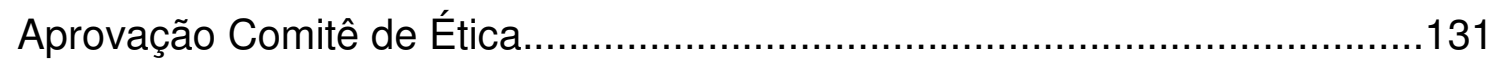

Termo de Consentimento Livre e Esclarecido............................................132 
Introducão e Revisão de $\underline{\text { Literatura }}$ 

1 INTRODUÇÃO E REVISÃO DE LITERATURA

\section{Biofilme dentário}

Atualmente, muitas espécies de microrganismos já foram detectadas na cavidade oral dos seres humanos e a grande parte delas encontra-se organizada na forma de biofilmes (WILSON et al., 2004). Enquanto uma grande maioria desses microrganismos são comensais, algumas espécies são identificadas como agentes etiológicos de uma variedade de doenças dentro e fora da cavidade oral (MEYER; FIVES-TAYLOR, 1998). Esses biofilmes formados principalmente por bactérias e fungos podem causar, por exemplo: cárie dentária, doença periodontal, candidose, infecções endodônticas, ortodônticas e em implantes (ALLAKER, 2010).

Biofilmes podem ser classificados como agregados de microrganismos nos quais as células se aderem umas às outras e à superfície (ALLAKER, 2010). Os biofilmes bacterianos são formados quando microrganismos se aderem a uma superfície sólida e envolvida por uma matriz de polissacarídeos extracelulares, podendo haver a formação de biofilmes a partir de uma ou múltiplas espécies (MAH e O'TOOLE, 2001; SPRATT \& PRATTEN, 2003).

Na superfície dos dentes, os colonizadores iniciais se aderem à película adquirida - uma camada de proteínas derivada da saliva e/ou dieta - a qual pode influenciar na colonização microbiana subseqüente (MARSH; BRADSHW, 1995). As forças envolvidas na agregação inicial das bactérias são essenciais no desenvolvimento do biofilme. Estas forças podem ser divididas em fracas de longo alcance $(>50 \mathrm{~nm})$ e fortes de pequeno alcance $(<5 \mathrm{~nm})$, o que poderá ter impacto no sucesso de antimicrobianos no desenvolvimento precoce do biofilme (ALLAKER, 2010). As comunidades iniciais encontradas no biofilme supragengival apresentam diversidade relativamente pequena, quando comparada à presente na placa madura. Os colonizadores inicias incluem Streptococcus oralis, Streptococcus sanguinis, e Streptococcus mitis. A coagregação posterior levará a um aumento do número de bactérias gram-negativas, por exemplo, Eikenella corrodens, Veillonella atypica, and Prevotella loescheii. A coagregação de Fusobacterium nucleatum normalmente é a divisão entre placa precoce e madura. Os últimos colonizadores incluem Aggregatibacter actinomycetemcomitans, Prevotellaintermedia, Treponema denticola, and Porphyromonas gingivalis (KOLENBRANDER et al., 2006). Biofilmes orais podem acumular tanto em tecidos duros como em tecidos moles, porém são 
sempre compostos de espécies microbianas embebidas numa matriz formada por componentes bacterianos, proteínas salivares, peptídeos e restos de alimentos. Essa matriz mantém a integridade do biofilme e providencia condições ideais de crescimento e sobrevivência das espécies (SUTHERLAND, 2001). Assim, pode-se perceber claramente a diferença de crescimento e desenvolvimento de biofilmes e células planctônicas, isso também leva a maior resistência a antimicrobianos, que normalmente necessitam de concentrações mil vezes maiores que as requeridas para matar microrganismos em estado planctônico (LEWIS, 2001; JENKINSON; LAMONT, 2005; PAN et al., 2010). Tem sido observado que bactérias inseridas nos biofilmes passam a exibir características fenotípicas distintas, o que também resulta no aumento de resistência dos biofilmes aos agentes antimicrobianos (EVANS; HOLMES, 1987; MAH, O'TOOLE, 2001, PAN et al., 2010).

A diversidade anatômica existente na cavidade oral e a interdependência entre as suas estruturas tornam o desenvolvimento dos biofilmes relevante. Contrariamente ao que ocorre nas superfícies mucosas onde há uma constante descamação da parede epitelial e consequente renovação dos microrganismos aderidos, os dentes constituem superfícies duras favoráveis à formação e maturação do biofilme bacteriano. O biofilme dentário é constituído por microrganismos encontrados nas superfícies dos dentes, apresentando composição bacteriana e bioquímica que podem variar na dependência de fatores intrínsecos e extrínsecos. O surgimento de doenças neste microambiente ocorre quando há um desequilíbrio no ecossistema do biofilme dentário formado (THYLSTRUP; FREJERSKOV, 1995; MARCOTTE; LAVOIE, 1998; MARSH, 1992; KOLENBRANDER, 2000; WATNICK; KOLTER, 2000; VON OKLE et al., 2010).

Por estar intimamente relacionada à formação de biofilmes dentários, a prevenção da doença cárie baseia-se principalmente na desorganização do biofilme tanto por ação mecânica como por ação de agentes químicos. Alguns estudos têm demonstrado que uma das formas de se prevenir tais doenças é por meio da remoção mecânica do biofilme dentário, a qual pode ser realizada com a utilização de escova dental, fio dental ou pela profilaxia profissional (LÖE; SILNESS, 1963; WILSON et al., 1996; ANDERSON 2003; FEJERSKOV; KIDD, 2005; KUMAR; GREEN, 2005, PAN et al., 2010; WONG et al., 2010).

O controle químico do biofilme dentário deverá ser empregado de forma suplementar, quando o controle mecânico, no sentido de evitar o acúmulo de 
bactérias sobre os dentes, não puder ser realizado diariamente ou estiver sendo realizado de forma inadequada (ANDERSON 2003; BOZKURT et al., 2005; PARASKEVAS, 2005; TELES;TELES, 2009).

Para o controle químico do biofilme, seja ele profilático ou terapêutico, são relatadas na literatura inúmeras substâncias antimicrobianas que diferem entre si na natureza química, no mecanismo de ação, na maneira como são veiculadas e na sua eficácia clínica. Dentre os agentes químicos, a clorexidina tem se mostrado eficiente para finalidade (ROSA; ROCHA, 1993; MATTHIJS; ADRIAEMS, 2002; de SOET et al., 2002; ANDERSON 2003; ERNST et al., 2005; PIOVANO et al., 2005; VAN STRYDONCK et al., 2005; SOUTHNER et al., 2006; TELES; TELES, 2009; PAN et al., 2010; WONG et al., 2010).

\section{Clorexidina}

A clorexidina é uma base forte estabilizada na forma de sal e é formada estruturalmente por moléculas catiônicas que consistem de dois anéis de 4clorofenol e dois grupos biguanidina conectados a uma cadeia central de hexametileno.

A clorexidina é um anti-séptico de moléculas carregadas positivamente, que apresenta um largo espectro antimicrobiano (ROSA; ROCHA, 1993; MATTHIJS; ADRIAEMS, 2002; FEJERSKOVV; KIDD, 2005). Sua molécula se liga, provavelmente, através de forças eletrostáticas aos grupos fosfato, carboxila ou sulfato, tanto na mucosa oral quanto nos microrganismos e na película adquirida (ROSA; ROCHA, 1993; MATTHIJS; ADRIAMES, 2002; FEJERSKV; KIDD, 2005). Sendo assim, a clorexidina compete com o cálcio, comprometendo a aderência bacteriana e, consequentemente, inibindo a formação do biofilme. Além disso, através da ligação com a parede celular microbiana altera o equilíbrio osmótico celular e leva a perda da integridade da membrana celular, levando a célula à morte (CCHUANNA-VASQUEZ; CURY, 2010).

A clorexidina atinge seu efeito antimicrobiano através de suas atividades bactericida e bacteriostática. Inicialmente, quando aplicada na forma de solução, gel ou verniz, atua como bactericida. Depois desse efeito bactericida inicial, ela se liga às mucosas e superfícies dos dentes e, posteriormente, é liberada de forma lenta, em concentrações bacteriostáticas, durante várias horas (ROSA; ROCHA, 1993; 
FEJERSKOV; KIDD, 2005; Van Strydonck et al., 2005). Após um bochecho com solução de clorexidina, aproximadamente $30 \%$ da droga fica retida na boca. Devido à sua natureza catiônica, ela adsorve-se a compostos aniônicos como glicoproteínas salivares, radicais fosfatados e carboxílicos presentes no biofilme dental como bactérias e polissacarídeos extracelulares, película dental e macromoléculas presentes na mucosa oral. Diante do exposto, o que diferencia a clorexidina dos demais agentes antimicrobianos é a sua substantividade, ou seja, sua capacidade de continuar sua ação antimicrobiana mesmo depois de um tempo em que foi aplicada (ROSA; ROCHA, 1993; MATTHIJS; ADRIAEMS, 2002; ZANATTA; KUCHENBECKER, 2007). Attin et al. (2003), concluiu que a clorexidina leva à redução dos valores de $S$. mutans de biofilme interdental por um período mínimo de 12 semanas.

Desta maneira, a clorexidina tem sido indicada, particularmente, em Odontopediatria, por períodos de tempo limitado e para casos específicos, tais como: pós-operatório de traumatismos bucais e/ou dentários e de cirurgias, gengivites acentuadas, alta atividade de cárie, elevada contagem de Streptococcus mutans na saliva e crianças comprometidas física e mentalmente com incapacidade de exercerem uma adequada higiene bucal por meio da remoção mecânica. Mas a despeito das suas vantagens, limitações são impostas ao seu uso principalmente porque acarreta o manchamento dos dentes e a perda do paladar (ROSA, ROCHA, 1993; MATTHIJS, ADRIAEMS, 2002; ULLBRO et al., 2005).

\section{Terapia Fotodinâmica antimicrobiana (TFDA)}

\section{TFD e ação antimicrobinana}

Desde a metade do último século, a terapia fotodinâmica antimicrobiana foi esquecida pela descoberta dos antibióticos. Porém, nas últimas décadas os interesses na utilização da TFDA como agente antimicrobiano vem aumentando pela grande emergência de espécies resistentes a antibióticos. Ela tem o potencial de ser um tratamento alternativo, principalmente nas infecções localizadas de pele e da cavidade oral.

A terapia é capaz de eliminar bactérias, fungos, vírus, e protozoários. 0 desenvolvimento de resistência após essa terapia não é comum, já que nas células dos microrganismos, o oxigênio singleto e os radicais livres interagem com muitas 
estruturas celulares em diferentes caminhos metabólicos. A TFDA é igualmente efetiva para bactérias resistentes ou susceptíveis a certo antibiótico, não selecionando as espécies resistentes (WAINWRIGHT; CROSSELEY, 2004). O fotossensibilizador pode ser aplicado topicamente, por injeção intersticial, aerossol ou instilação. Muitas publicações têm mostrado que a terapia também é eficiente no tratamento de infecções localizadas (HAMBLIN; HASAN, 2004; WAINWRIGHT; CROSSLEY, 2004).

Existem diversos fotossenssibilizadores utilizados com esta finalidade, dentre eles: o azul de metileno, o azul de Toluidina $O$ (TBO), clorinas, porfirinas (hematoporfirina, Photofrin $\AA$, ALA); eritrosina (WAINWRIGHT, 1998). A fotossensibilidade da bactéria parece estar relacionada com o tipo de droga. Em geral, fotossensibilizadores neutros ou aniônicos são efetivos para eliminar bactérias gram-positivas, enquanto que nas bactérias gram-negativas somente se acumulam na membrana. A porosidade relativa da membrana de espécies gram-positivas permite ao fotossensibilizador se difundir para sítios sensitivos, já a membrana das gram-negativas atua como uma barreira física entre a célula e o ambiente. Para estas, as drogas devem ser catiônicas, ou ser conjugadas por sensibilizadores como anticorpos monoclonais, que conseguem atravessar a membrana. (WAINWRIGHT, 1998; ROVALDI et al., 2000; HAMBLIN; HASAN, 2004; KÖMERIK; MACROBERT, 2006).

O desenvolvimento de resistência após essa terapia não é comum, já que nas células dos microrganismos, o oxigênio singleto e os radicais livres formados no processo interagem com muitas estruturas celulares em diferentes caminhos metabólicos. A TFDA é igualmente efetiva para bactérias resistentes ou susceptíveis a alguns antibióticos, não selecionando as espécies resistentes (WAINWRIGHT; CROSSLEY, 2004).

A TFDA é baseada no princípio de que a interação da luz num comprimento de onda adequado com um composto não tóxico (fotossensibilizador), na presença de oxigênio, causa a citotoxicidade celular. Isso é resultado da reação envolvida, que decorre primariamente da excitação eletrônica do corante pela luz, levando-o do estado fundamental ao estado excitado chamado tripleto, de meia vida curta. Nessa etapa, as moléculas podem retornar ao estado fundamental emitindo energia na forma de fluorescência, através da liberação de fótons, ou progredir na cadeia de reações químicas até retornar ao estado fundamental. As moléculas no 
estado tripleto podem sofrer dois tipos de reações. Na reação do tipo I, as moléculas interagem diretamente com os substratos biológicos para formar radicais livres como super-óxido, hidroxila e peróxido. Na reação do tipo II, as moléculas transferem sua energia diretamente para o oxigênio, formando o oxigênio singleto altamente reativo e responsável pela morte celular (TOREZAN, 2000; LUI et al., 1999; NELSON, 1997; FREITAS, 1991; KENNEDY, 1992; MARTHY, 1990; ROBERTS et al., 1995; TROMBERG et al., 1990). Ambas as reações podem ocorrer simultaneamente e a razão entre elas é influenciada pelas características do fotossensibilizador, substratos intracelulares e a concentração de oxigênio do meio. $\mathrm{Na}$ ausência de oxigênio o efeito é praticamente inexistente. (TOREZAN, 2000; NELSON, 1997; GROSSMAN, 1997).

A produção de oxigênio singleto é o mecanismo mais importante para a TFDA, porém existe outro importante mecanismo: a indução da morte celular por apoptose, que pode ocorrer por via mitocondrial ou por alteração da membrana plasmática, através da inibição das proteínas da família Bcl-2 (inibidoras da apoptose celular) e a ativação das caspases (proteínas iniciadores e executoras da apoptose) (OLEINICK et al., 2002). A droga por si só é um agente reativo dentro da célula, destruindo vários substratos celulares importantes. Durante a exposição à luz, a droga localizada na mitocôndria pode induzir a apoptose, enquanto aquela localizada nos lisossomos e membranas celulares pode causar a necrose (CASTANO et al., 2005). O efeito apoptótico amplia a eficácia da reação. A reação é acompanhada por uma resposta imune inflamatória complexa (DOUGHERTY et al., 1998). Uma invasão de neutrófilos, mastócitos e monócitos/macrófagos foram observadas durante e após a aplicação da TFDA em modelos de tumor em ratos (KROSL et al., 1995). Isto pode ser seguido de uma ativação de Linfócitos T (NOWIS et al., 2005). Após a iluminação do fotossensibilizador, uma resposta aguda de stress leva à mudança no metabolismo de cálcio e de peptídeos e à produção de citocinas.

A TFD teve início há 4.000 anos com os egípcios, através da ingestão de plantas e luz solar, para tratar doenças como o vitiligo. Entretanto, a técnica começou a ser empregada com sistemática científica apenas no século XX. Em 1900, Raab descreveu a ação de corantes acridina e luz solar sobre Paramecia, demonstrando que este organismo unicelular pode morrer sob essas condições (RAAB et al., 1900). Finsen, em 1901, apontou que a radiação solar poderia ser 
utilizada na cura de Lupus vulgaris (BONNET et al., 1999). Em 1903, Trappeiner utilizou a aplicação tópica do corante eosina e exposição à luz para o tratamento de um câncer de pele (VON TAPPEINER, 1903). Em 1913 Meyer-Betz fez uma autoinjeção de $200 \mathrm{mg}$ do que ele pensava ser hematoporfirina pura e não sentiu nenhum efeito, porém ao se expor à luz teve fotossensibilidade na pele por vários meses. Policard, em 1925, estudou porfirinas objetivando a produção de efeitos fototóxicos em tecidos, principalmente em tumores malignos (STENBERG et al., 1998).

Embora a TFD tenha sido originalmente desenvolvida objetivando o combate ao câncer em suas diversas formas, vários estudos têm deixado evidente 0 seu grande potencial no que concerne a outras moléstias. Nesse rol incluem-se a psoríase (LEVY, 1995; WEINSTEIN et al., 1991), onde resultados muito promissores foram obtidos; degeneração macular da retina; condições autoimunes; arteriosclerose e restenose; remoção de verrugas na laringe (BEM-HUR et al., 1993); tratamento de micoses oriundas de fungos (WOLF et al., 1994); e destruição de infestações bacterianas resistentes a tratamentos tradicionais à base de antibióticos (VAN DER MEULENn et al., 1997).

As vantagens da terapia fotodinâmica antimicrobiana em relação ao uso dos agentes antimicrobianos tradicionais são: eliminação rápida (imediata) da célula bacteriana, não sendo necessária a manutenção do agente químico em altas concentrações sobre as lesões por longos períodos de tempo, como ocorre com os agentes anti-sépticos e antibióticos; a morte celular mediada pela liberação de radicais livres, que torna 0 desenvolvimento de resistência pelos microrganismos improvável; terapia confinada à área da lesão pela aplicação tópica cuidadosa do corante e restrição da irradiação, já que o uso do fotossensibilizador ou da luz sozinhos não apresentam efeito significativo sobre a viabilidade das bactérias (Allison et al., 2005, 2006, Konopka et al., 2007, Wilson, 2004).

A TFDA tem sido eficaz no tratamento de infecções por bactérias, fungos, vírus e parasitas, principalmente pela ausência de efeitos genotóxicos e mutagênicos. Essa terapia também é uma nova modalidade terapêutica para a desorganização da placa bacteriana. A cavidade oral é um local de fácil aplicação da terapia, já que é acessível para a iluminação (KONOPKA et al., 2007).

\section{Fontes de luz}


A TFDA requer uma luz que ativa a droga fotossensibilizadora. Esta luz deve ser monocromática, centrada na banda de absorção do fotossensibilizador utilizado, ou seja, conseguindo excitá-lo, transferindo energia a fim de que a reação fotodinâmica seja desencadeada. Os tecidos humanos transmitem eficientemente luz vermelha, e uma longa ativação do fotossensibilizador resulta na penetração profunda dos raios (KONOPKA et al., 2007),

Com relação às fontes de luz, as primeiras a serem utilizadas foram lâmpadas convencionais com luz não coerente e policromática. Desde o surgimento dos primeiros equipamentos a laser, esta fonte de luz tem sido atraente para a TFD devido as suas propriedades: concentração elevada de energia, pouca dispersão de energia à medida que a luz se propaga, coerência e monocromaticidade, possibilidade de iluminação de um meio composto por materiais diversos e somente interação com um determinado componente (seletividade).

Com o desenvolvimento dos LEDs (diodos emissores de luz), começaram a surgir estudos que aplicam tal fonte de luz à terapia fotodinâmica. Laser e LED produzem irradiação num comprimento de onda específico, porém a irradiação LED é emitida numa faixa mais ampla do espectro, não é coerente e colimada como a irradiação a laser. Estudos têm verificado eficiência dessa fonte de luz na TFDA. Comparado ao laser, os LEDs apresentam custo menor.

\section{Fotossensibilizadores}

Além da luz, a TFDA requer um corante fotossensível, que é o principal ativador do processo fotodinâmico. Este deve possuir propriedades físico-químicas, farmacológicas e fotobiológicas que o qualifiquem como bom agente para a terapia, isto é, ter alta eficiência e efeitos colaterais mínimos. (KONOPKA et al., 2007).

A história da chamada primeira geração de drogas para a TFD, à base de derivados hematoporfirínicos, começa com Schwartz no início da década de 50 . Ele mostrou que nos experimentos de Meyer-Betz, o princípio ativo não era a hematoporfirina (pois esse composto é facilmente eliminado do organismo), mas na realidade tratava-se de uma mistura de diversas substâncias oligoméricas provenientes do método original de síntese e isolamento da mesma. Schwartz enriqueceu a mistura de oligômeros (chamou o preparado de $\mathrm{HpD}$ ) e na década de 60 , Lipson sob orientação de Schwartz investigou o acúmulo preferencial deles em tumores, implantados em camundongos e ratos e observou que a incidência de luz 
proporcionava regressão da doença (STENBERG, et al., 1998). Como resultado desses estudos, no final da década de 60, Lipson obteve sucesso no tratamento de uma mulher que possuía câncer de mama usando $\mathrm{HpD}$ e irradiação seletiva do tumor, marcando assim, o início da TFD como terapia clínica para câncer (LIPSON, 1966).

A partir da década de 70, várias preparações de derivados porfirínicos começaram a ser testadas para uso em TFD, culminando com o desenvolvimento do Photofrin II (refinamento do $\mathrm{HpD}$ ) por Dougherty (DOUGHERTY et al., 1987). Posteriormente, no fim da década de 80, a empresa QLT Inc. através de purificações do preparado anterior, via processos de liofilização, chegou ao medicamento Photofrin. O Photofrin é o único medicamento aprovado pela FDA/EUA (Food and Drug Administration) para o tratamento do câncer com a técnica de TFD (aprovação datada de 22 de dezembro de 1998).

A busca de novas drogas fotossensíveis, a chamada segunda geração, levou a compostos que apresentaram melhorias nas propriedades foto-físicas em relação ao Photofrin. Embora de baixo impacto para a área médica, em 7 de dezembro de 1999, a FDA aprovou o uso do Levulan Kerastick, uma pró-droga (composto base que irá produzir o princípio ativo) para lesões de pele na face e escalpo. De significante impacto foi a aprovação do medicamento Visudyne, desenvolvido pela empresa QLT Inc. em associação com a University of British Columbia, sob supervisão do Professor Dr. D. Dolphin. O principio ativo é o composto BPDMA, uma benzoporfirina que na forma injetável foi chamada verteporfina. O medicamento, aprovado para o tratamento de degeneração macular, também está sendo testado pela QLT e UBC na terapia do câncer, AIDS e demais doenças já mencionadas. Visudyne foi aprovado pelas autoridades de saúde da Suíça (16 de dezembro de 1999), EUA / FDA (12 de abril de 2000) e Grã-Bretanha / União Européia (28 de julho de 2000).

A terceira geração inclui drogas que são modificadas por anticorpos monoclonais ou por um sistema de proteínas/receptores, e conjugação com um tag radioativo (VROUENRAETS et al., 2003; SHARMAN et al., 2004; ALLISON et al., 2006; SOLBAN et al., 2006). As marcas celulares são principalmente marcadores de superfície do tumor, receptores de proteínas de baixa densidade, receptores de tranferrina, receptoers de ácido fólico, transportadores de glicose, receptores de integrina e de insulina. Existem poucos estudos com essas drogas. 
Muitos componentes naturais e sintéticos apresentam potencial fotossensibilizador. Um fotossensibilizador ideal deveria ser não tóxico e apresentar toxicidade local, apenas pós-iluminação. $O$ agente fotossensibilizador pode ser injetado intravenosamente, oralmente ou aplicado topicamente.

As drogas fotossensibilizadoras precisam ter uma série de propriedades gerais, dentre elas são importantes: características fotofísicas favoráveis; baixa toxicidade no escuro (baixa citotoxicidade); fotossensibilidade não prolongada; simplicidade na formulação, reprodutibilidade e alta estabilidade da formulação (tempo mínimo de 2 anos) que, geralmente, é mantido seco, bastando ao profissional adicionar água ou soro fisiológico e agitar; farmacocinética favorável (rápida eliminação do corpo); facilidade de manuseio sintético que permita efetuar modificações para otimizar as propriedades desejáveis; facilidade de obtenção em escala industrial a custos reduzidos e com boa reprodutibilidade; facilidade de análise total dos componentes da fórmula, inclusive com fornecimento de roteiros de validação e alta afinidade e penetração no tecido doente em detrimento do tecido saudável (seletividade). (STEMBERG et al., 1998)

É importante frisar que o medicamento deve atender a esse conjunto de propriedades gerais para ser considerado uma droga comercialmente viável e eficaz na sua ação terapêutica. Daí advém à importância da formulação empregada. (SIMPLICIO et al., 2001)

Quanto às características fotofísicas favoráveis, um fator importante é o comprimento de onda da luz necessária à foto-excitação do composto. Na região visível, quanto maior o comprimento de onda da luz incidente, maior é o seu grau de penetração no tecido. Portanto, as drogas desenvolvidas para uso em TFD devem ser corantes (cromóforos) que absorvam na região próxima ao infra-vermelho (LEVY, 1995). Acima de $800 \mathrm{~nm}$ ocorre absorção da radiação pela água, o que restringe o comprimento de onda a este limite superior (SIMPLICIO et al., 2001).

Um processo adicional que o sensibilizador (droga) sofre é o de fotobranqueamento, causado por modificações na estrutura da molécula através de reações paralelas. O sentido do termo foto-branqueamento é o de que a molécula sofrerá reação e o produto não irá mais absorver luz no comprimento de onda de incidência, deixando assim de exercer sua ação terapêutica. Dessa forma, as primeiras propriedades fotofísicas in vitro investigadas em moléculas candidatas para a TFD são: forte absorção de luz na região acima de $650 \mathrm{~nm}$, onde a luz 
apresenta maior penetração no tecido; alto rendimento quântico de estado triplete; alto rendimento quântico de geração de oxigênio singlete e baixo rendimento de reação de foto-branqueamento do cromóforo.

O TBO é um corante orgânico redox da classe das fenotiazinas (CHEN et al. 1995). Ele tem se mostrado efetivo em diversos estudos como agente fotossensibilizador na TFDA (HAAS et al., 1997; O'NEILL et al., 2002; SEAL et al., 2002; ZANIN et al. 2005; BEVILACQUA et al., 2007; SHARMA et al., 2007).

Clorofilas são pigmentos verdes encontrados em plantas. De um modo geral, são encontradas em todos os organismos capazes de realizar fotossíntese. Tanto as clorofilas quanto o processo de fotossíntese são restritos ao reino vegetal (DOLPHIN, 1978). Portanto, a Clorofila líquida (CL) é um corante natural, de fácil acesso, custo reduzido e que não apresenta propriedades tóxicas para a boca. $A$ estrutura básica de sua molécula é um anel porfirínico coordenado por um átomo central. É muito similar ao grupo heme da hemoglobina, mas difere o átomo central. Apesar das vantagens desse corante, poucos são os estudos que o utilizam como droga fotossensibilizadora na TFD (SOARES, 2006).

\section{TFD contra microrganismos planctônicos}

Muitos autores têm relatado a ação antimicrobiana da terapia fotodinâmica sobre bactérias crescidas em caldo de cultura (DOBSON; WILSON, 1992; ZANIN et al., 2002; WILLIAMS et al., 2003). Tem-se verificado efeito letal da irradiação do laser associada ao uso de droga fotossensibilizadoras contra microrganismos (BACH et al., 2000; DORTBUDAK et al, 2001; SARKAR et al., 1993).

Van der Meulen (1997), testou o a ALA (ácido aminolevulínico) como fotossensibilizador na terapia fotodinâmica contra Haemophilus parainfluenzae,utilizando um laser de $630 \mathrm{~nm}$ como fonte de luz. O número de microrganismos decresceu com concentrações de ALA superiores a 0,3mM. Não houve influência da luz quando não havia fotossensibilizador. Amostras que foram irradiadas sem a presença do fotossensibilizador, também não mostraram diferença na sobrevida. A dose de luz de $10 \mathrm{~J} / \mathrm{cm}^{2}$ foi escolhida como ótima. Portanto a TFD com ALA foi efetiva contra esse tipo de bactéria Gram negativa. No entanto, um aumento da dose de luz, leva a um decréscimo da morte celular, devido ao fotobranqueamento do ALA. 


\section{Cultura dos microrganismos Pseudomonas aeruginosa e}

Staphylococcus aureus foram sensibilizadas por TBO e irradiadas por dois tipos de laser: Laser de Hélio-Neônio ( $\mathrm{He}-\mathrm{Ne}$ ) ou Laser de Fosfeto Indio-Gálio-Alumínio (InGa-Al-P) de $5 \mathrm{~mW}$. Ambas as fontes de luz mostraram certo grau de inibição das bactérias, sendo o segundo mais efetivo (DE SIMONE et al., 1999).

Analisou-se o efeito da TFD sobre patógenos periodontais utilizando-se clorina e6 conjugado a uma pentalisina como fotossensibilizador e irradiação com laser de diodo. Houve um efeito ótimo ta terapia quando a concentração do fotossensibilizador foi igual ou maior a $2,5 \mathrm{mM}$ e irradiação mínima de $19 \mathrm{~s}$ ou $1,9 \mathrm{~J}$ (ROVALDI et al., 2000).

Zeina et al, 2001, aplicaram a TFD em um mix celular formado por espécies colonizadores da pele: Staphylococcus aureus, S. epidermidis, Streptococcus pyogenes, Corynebacterium minutissimum, Propionibacterium acnes e Candida albicans, usando como fotossensibilizador o azul de metileno $(100 \mu \mathrm{g} / \mathrm{mL})$. As culturas de células foram irradiadas com uma luz policromática visível emitida por um projetor de slide equipado por uma lâmpada de 250W (comprimento de onda de 400-700nm) ou pela luz solar por diferentes tempos (10 a 60 minutos). Os resultados demonstraram morte dos microrganismos proporcional à intensidade da luz. O número de bactérias já havia iniciado a morte com 10 minutos de irradiação, enquanto os fungos necessitaram de 30 minutos, condição observada com ambas as fontes de luz. Esses dados revelam que tal terapia poderia ser uma alternativa ao tratamento antimicrobiano na pele, ou como assepsia, já que todas as espécies foram susceptíveis, lembrando que células eucarióticas (fungos) foram mais resistentes (ZEINA et al., 2001).

Um estudo foi realizado para entender se os efeitos bactericidas da fototoxicidade são dependentes do comprimento de onda da luz, ou dosedependente na eliminação de periodontopatógenos, como Actinobacillus actinomycetemcomitans, Fusobacterium nucleatum, Porphyromonas gingivalis, Prevotella intermedia, e Streptococcus sanguis. Esses patógenos foram expostos ao laser He-Ne (632.8 nm, $30 \mathrm{~mW})$, ao laser de diodo $(665 \mathrm{~nm}, 100 \mathrm{~mW})$, e a outro laser de diodo $(830 \mathrm{~nm}, 100 \mathrm{~mW})$, na presença ou ausência de azul de metileno (fotossensibilizador). A combinação mais efetiva (95-99\% de taxa de morte bacteriana) foi obtida ao se utilizar azul de metileno associado ao laser de diodo $665 \mathrm{~nm}$ a $100 \mathrm{~mW}$ (CHAN et al, 2003). 
Paulino et al. (2004), investigaram o efeito da TFDA sobre Streptococcus mutans e fibroblastos. A viabilidade celular foi avaliada após as células serem tratadas por Rosa Bengal em diferentes concentrações e irradiadas pela luz de um fotopolimerizador manual por diferentes períodos de tempo. Foi observado que a luz sozinha não é tóxica e que o fotossensibilizador só passa a ser tóxico em concentrações acima de $2.5 \mathrm{mM}$. A TFDA levou a morte dos microrganismos sem causar efeitos citotóxicos aos fibroblastos, quando a concentração do fotossensibilizador foi de $0.5 \mathrm{mM}$.

Similarmente a outros fungos, o tratamento da Candida albicans pela TFDA é mais difícil que contra uma bactéria gram positiva. Isso é atribuído à presença de uma membrana nuclear e uma ampla camada de células (DEMIDOVA; HAMBLIN, 2005).

BLISS et al. (2004) estudaram os efeitos do Photofrin $^{\circledR}$ na TFDA contra espécies de Candida. A fonte de luz utilizada por uma lâmpada de argônio. A TFDA teve efeito inibitório de maneira dose-dependente da concentração do fotossensibilizador. Uma espécie de C. glabrata absorveu pobremente o Photofrin ${ }^{\circledR} \mathrm{e}$ foi resistente à morte depois da irradiação. Em contraste, duas espécies diferentes de $C$. albicans mostraram níveis semelhantes de sensitividade à terapia. Além disso, uma espécie referência de $C$. krusei, que apresenta maior resistência ao fluconazol quando comparado a $C$. albicans, apresentou sensibilidade à terapia semelhante à apresentada pela $C$. albicans, quando as concentrações de Photofrin ${ }^{\circledR}$ foram maiores que $3 \mu \mathrm{g} / \mathrm{mL}$. Os resultados indicam que esta pode ser uma alternativa de tratamento a ser utilizada de maneira coadjuvante às terapias tradicionalmente usadas contra Candida, particularmente em infecções superficiais, que podem ser irradiadas pela luz.

Uma contagem do número de colônias de Candida albicans foi feita por Monfrecola et al. (2004), após aplicação de ALA e irradiação por luz visível. Inicialmente foram preparadas suspensões de C. albicans. Depois cada $30 \mu \mathrm{l}$ de suspensão foram incubadas, no escuro, com concentrações crescentes de ALA e então irradiadas com a luz. Imediatamente após a sessão de irradiação, as suspensões do fungo foram plaqueadas em Agar Sabauraud e contadas após 48h. Como controle havia um grupo não tratado com ALA-PDT e um grupo somente tratado com ALA. Nos grupos controles, não houve modificação do número de colônias, porém naqueles em que a TFD foi realizada a partir de uma concentração 
de ALA de $300 \mathrm{mg} / \mathrm{mL}$, houve redução no número de colônias. Essa inibição só foi completa a partir da concentração de $600 \mathrm{mg} / \mathrm{mL}$. Esses resultados mostraram que a TFDA utilizando ALA como fotossensibilizador pode ser efetiva para tratamento de candidose.

Wong et al. (2005), estudaram os efeitos da TFDA contra Vibrio vuinificus (bacilos gram negativos) in vitro, utilizando TBO como fotossensibilizador e luz visível para a irradiação. Baixas doses de TBO quando associadas à luz mataram as bactérias nos testes in vitro, mas não influenciaram no crescimento quando utilizadas isoladamente. Já concentrações mais altas do corante conseguem inibir o crescimento bacteriano. Ainda foi mostrado que a terapia inibe a motilidade, a atividade proteolítica, perturba os flagelos e causa mudanças na parede celular do microrganismo. Também foram estudados os efeitos destes parâmetros de TFD contra Vibrio vuinificus in vivo (infecção de feridas por tal bactéria). Pode-se perceber que a terapia protege animais de infecções letais causadas por esse microrganismo. Somente 1 dos 24 ratos morreram após aplicação do corante seguido de irradiação, enquanto no grupo controle, todos morrera após 24-36h de infecção.

A incubação de Candida albicans e Trichophyton interdigitale com concentrações de $10 \mathrm{mM}$ de ALA por 30min e 6h, respectivamente, associado a irradiação por luz vermelha causaram redução na viabilidade desses microrganismos em $87 \%$ e $42 \%$ (DONNELLY et al., 2005). Outro estudo confirmou a eficácia da TFD no tratamento de infecções mucocutâneas de Candida albicans mostrando que, através da droga fotossensibilizadora Photofrim ${ }^{\circledR}$, a TFD foi efetiva. A resposta foi dependente da dose da droga. Além disso, outros estudos mostraram que os mecanismos usados pela $C$. albicans para subverter a defesa não funcionam durante a TFD, o que a torna uma possível alternativa para o tratamento de candidose (CHABRIER-ROSELLO et al., 2005).

Demidova et al. (2005) infectaram feridas de ratos com Escherichia coli ou Pseudomonas aeruginosa e aplicaram a Terapia Fotodinâmica utilizando o corante clorina e6 e um laser de diodo como fonte de luz. Houve diminuição da contaminação para ambas as espécies. Para E. coli houve redução da contaminação de maneira dose-dependente da luz, chegando até $99 \%$ e as feridas pareceram cicatrizar relativamente mais rápidos. Em relação a $P$. aeruginosa, que leva à septicemia rapidamente, a aplicação de TFD permitiu a sobrevivência de $90 \%$ 
dos animais tratados, que apresentavam ainda alguns sintomas de infecção, mas se recuperaram rapidamente, ao contrário dos animais do grupo controle que morreram.

Culturas de Aggregatibacter actinomycetemcomitans foram tratadas com Verde de Malaquita e expostas a irradiação por laser de diodo de 30mW. Houve inativação dependendo da dose de energia. Três minutos de irradiação levou a morte de $97,2 \%$ das bactérias. Quando o tempo foi aumentado para 5 minutos, notou-se morte de $99,9 \%$. Os resultados demonstraram potencial desse fotossensibilizador contra microrganismos da doença periodontal (PRATES et al., 2006).

Testou-se Terapia Fotodinâmica contra Staphylococcus aureus resistentes a penicilina, em cultura, utilizando-se uma protoporfirina IX e protoporfirina com duas moléculas de Arginato (PPArg $)_{2}$ como fotossensibilizadores e uma luz polarizada monocromática como fonte de luz. A terapia teve efeito antibacteriano com ambos os fotossensibilizadores, após iluminação por 60 minutos com uma dose de $12 \mathrm{~J} / \mathrm{cm}^{2}$, sendo tal efeito ainda maior com o PPArg 2 (GRINHOLC et al., 2007).

Chabrier Roselló, em 2007, mostraram que espécies de C. albicans e Candida glabrata que apresentam deficiência respiratória e, portanto, um padrão de resistência a uma família de antifúngicos, aos peptídeos antimicrobianos de histatina presentes na saliva e outros tipos de estresse tóxico são afetadas pela TFDA utilizando o meso-tetra (N-methyl-4-pyridyl) porphine tetra tosylate (TMP) como fotossensibilizador. Em contraste a esse padrão de resistência, tais espécies foram mais sensíveis à TFDA quando comparadas às espécies padrão. Esses dados sugerem que a função mitocondrial normal (das espécies não resistentes) podem providenciar um nível basal de defesa contra os mecanismos oxidativos que as agridem pela TFD (CHABRIER ROSELLO et al., 2008).

Giroldo et al, em 2007, estudaram o efeito da TFDA na permeabilidade da membrana de C. albicans, utilizando azul de metileno como fotossensibilizador e laser de diodo como fonte de luz. Os resultados demonstraram que essa combinação promoveu um decréscimo no crescimento de Candida e a inibição foi mais pronunciada na presença de corante na concentração $0,05 \mathrm{mg} / \mathrm{mL}$ e com densidade de energia do laser de $28 \mathrm{~J} / \mathrm{cm}^{2}$. O decréscimo do crescimento foi associado com um aumento na permeabilidade da membrana celular, o que sugere 
que os mecanismos de dano da TFD utilizando tal corante podem ser exercidos na membrana plasmática das células (GIROLDO et al., 2007).

Cultura de Enterococcus faecalis foi incubada com azul de metileno dissolvido em água ou em uma mistura de glicerol, etanol e água. Em seguida, as células foram irradiadas com laser de diodo. $O$ efeito da TFDA na viabilidade celular, a integridade da parede celular e os danos no DNA e proteínas de membrana das células foram analisados. A ação bactericida foi maior quando o corante foi dissolvido na mistura glicerol, etanol e água, o que também revelou maior dano no DNA e maiores prejuízos na parede celular. No entanto, ambas as condições mostraram degradação similar das proteínas de membrana. Este estudo demonstrou que a terapia destrói a integridade funcional da parede celular, do DNA e das proteínas de membrana e esses efeitos são influenciados pelo solvente usado no fotossensibilizador (GEORGE; KISHEN, 2008).

Em 2009, Souza et al. avaliaram os efeitos da TFDA na viabilidade de C. albicans utilizando Azul de Metileno, TBO e verde de Malaquita como fotossensibilizadores. A fonte de luz foi um laser de baixa potência. Os três corantes promoveram redução do número de colônias. O laser sozinho também mostrou certo poder antifúngico, porém menor. $O$ efeito do TBO foi melhor que os outros, embora sem diferença significante. Além disso, quanto maior a dose de energia usada, maior a efetividade da terapia (SOUZA et al., 2009).

Pasyechnikova et al. (2009) também estudaram a influência da TFD em culturas de $C$. albicans usando azul de metileno e laser. A supressão máxima de crescimento do microrganismo foi obtida utilizando-se o corante na concentração $0,1 \%$ e irradiação durante 3 minutos. O microrganismo fica mais sensível a fotoativação à medida que a concentração do fotossensibilizador foi aumentada.

A ação fotodinâmica do 5-(4-trifluorophenyl)-10,15,20-tris(4trimethylammoniumphenyl)porphyrin iodide $\left(\mathrm{TFAP}^{3+}\right)$ e do 5,10,15,20-tetra(4-N,N,Ntrimethylammonium phenyl)porphyrin $\mathrm{p}$-tosylate $\left(\mathrm{TMAP}^{4+}\right)$ foi estudada in vitro sobre Candida albicans. Os resultados foram comparados com os resultados obtidos pelo fotossensibilizador 5,10,15,20-tetra(4-sulphonatophenyl)porphyrin $\left(\right.$ TPPS $\left.^{4+}\right)$, que é uma molécula aniônica. Os resultados mostraram que essas porfirinas catiônicas ligam-se rapidamente em $C$. albicans. Em contraste, TPPS ${ }^{4+}$ é pobremente absorvido pelo fungo. A inativação do microrganismo pela fotossensibilização aumenta com o aumento da concentração do fotossensibilizador, sendo efetiva 
quando as células são tratadas com $5 \mathrm{mM}$ da porfirina catiônica e irradiados por 5 minutos. No entanto, a fototoxicidade decresce com o aumento da densidade celular, já que esse aumento leva a uma baixa ligação nas células. Assim, a atividade fotodinâmica do $\mathrm{TFAP}^{3+}$ é similar à produzida pelo $\mathrm{TMAP}^{4+}$, enquanto que não se observou efeito importante para TPPS ${ }^{4+}$. A inativação fotodinâmica também foi avaliada no crescimento de colônias de $C$. albicans sobre superfície de agar. As porfirinas catiônicas levaram a um atraso do crescimento das colônias e não se observou viabilidade das células depois de 3 horas de irradiação, indicando uma inativação completa das células fúngicas. Estes resultados indicam que porfirinas catiônicas são fotossensibilizadores interessantes para inativação de fungos em suspensões ou infecções localizadas (CORMICK et al., 2009).

Um estudo avaliou a TFDA contra Staphilococcus aureus utilizando como fotossensibilizadores diferentes concentrações de um derivado de hematoporfirina (Photogen ${ }^{\circledR}$ ) e duas diferentes fontes de luz (laser e LED). Todos os grupos, nos quais a terapia foi aplicada, mostraram decréscimo na contagem bacteriana, mostrando maior efetividade quando doses mais altas do fotossensibilizador e da fonte de luz foram usadas. Laser e LED tiveram efeitos semelhantes, os parâmetros (concentração do fotossensibilizador e tempo de irradiação) influenciaram mais que o tipo de luz (GOIS et al, 2009).

ARAÚJO et al. (2009) avaliaram o efeito antimicrobiano da PDT em suspensões de Streptococcus mutans, utilizando uma luz vermelha produzida por um laser em combinação com TBO ou Azul de Metileno. Quando o fotossensibilizador foi utilizado na concentração de $25 \mathrm{mg} / \mathrm{mL}$, houve redução bacteriana de $70 \%$ para TBO e $73 \%$ para Azul de metileno. Na concentração de $5 \mathrm{mg} / \mathrm{mL}$, essa redução foi de $48 \%$ para o azul de Metileno. Na concentração mais alta, ambos os fotossensibilizadores associados à luz laser tiveram um bom potencial na TFDA contra este tipo de microrganismo

HAUKVIK et al. (2009), estudaram os efeitos fototóxicos da curcumina contra Enterococcus faecalis e Streptococcus intermedius (bactérias gram positivas) e contra Escherichia coli (bactéria gram negativa). O fotossensibilizador foi adicionado e depois de 30 minutos, as culturas celulares foram irradiadas com uma luz azul emitida por tubos fluorescentes. Mudanças no tempo de incubação, na dose de irradiação e no modo de preparar o corante influenciaram nos resultados fototóxicos. 
Um estudo teve como objetivo investigar a fototoxicidade do Photosan ${ }^{\circledR}$ em combinação com EDTA e irradiação por um fotopolimerizador utilizado em odontologia, contra bactérias patogênicas da cárie, de falhas de tratamento endodôntico e periodontite. Detectou-se que o corante foi absorvido por Streptococcus mutans e Enterococcus faecalis, mas não por Aggregatibacter actinomycetemcomitans (Aa). A adição de $10 \%$ de EDTA permitiu a absorção também por Aa. A morte de $S$. mutans e $E$. faecalis foi dependente da concentração do fotossensibilzador e da dose de luz, alcançando mais de $99 \%$ de morte. $\mathrm{Na}$ presença de $10 \%$ de EDTA, Photosan ${ }^{\circledR}$ levou a redução na viabilidade de Aa em até $4 \log 10$, comparado aos grupos controle. Portanto, esses parâmetros da TFD foram efetivos contra essas bactérias orais, podendo ser uma importante ferramenta para destruição de bactérias orais (MAISCH et al., 2009).

Bolean et al. (2010) testaram a expressão de GroEL (que indica condições de estresse) por $S$. mutans após aplicação de TFD, utilizando-se rosa bengal como droga fotossensibilizadora. A expressão de GroEL foi mais alta após a aplicação da terapia e similar a induzida por um controle positivo ( $\mathrm{NaCl}$ ). PDT pode causar efeitos similares a outras condições de estresse em $S$. mutans, induzindo a morte celular, o que indica a incapacidade do microrganismo de se proteger contra os efeitos deletérios causados pela terapia com esse fotossensibilizador.

Estudo investigou o efeito da terapia fotodinâmica antimicrobiana sobre Candida dubliniensis utilizando extratos de Alternanthera marítima. Laser de diodo serviu para a iluminação das amostras tratadas com os extratos. Resultados sugeriram inibição de crescimento da espécie após a terapia. Portanto, ação antimicrobiana foi produzida pela associação do corante e luz, mostrando que esse produto natural pode ser usado como fotossensibilizador (GASPARETTO et al., 2010).

\section{TFDA e biofilme}

Muitos autores têm relatado a ação antimicrobiana da terapia fotodinâmica sobre bactérias crescidas em caldo de cultura (DOBSON; WILSON, 1992; WOOD et al., 1997; WILLIAMS et al., 2004; ZANIN et al., 2005, 2006), mas poucos são os estudos que avaliam a ação antimicrobiana da terapia fotodinâmica sobre biofilmes cariogênicos (WOOD et al., 1999; O'NEILL et al., 2002). A comprovação da eficácia dessa terapia sobre o biofilme dentário humano poderá ter 
um impacto positivo para a Odontologia, favorecendo a implementação de novos protocolos de controle químico do mesmo.

Biofilme de Streptococcus sanguinis, Porphyromonas gingivalis, Fusobacterium nucleatum e Aggregatibacter actinomycetemcomitans foram preparados e neles testado a habilidade de sensibilização das bactérias após aplicação de diversos corantes e irradiação pela luz de um Laser de Helio-Neônio. Foi detectada morte celular dos quatro microrganismos alvos após a aplicação dos corantes TBO e Azul de Metileno e exposição na luz de apenas 30 segundos. Já os fotossensibilizadores ftalocianina dissulfonatada, Haematoporfirina $\mathrm{HCl}$ e Haematoporfirina Ester não foram efetivos para todos os microrganismos. Esses achados sugerem que a fotosensibilização letal pode ser um efetivo meio de eliminação de bactérias periodontopatogênicas da placa dentária (DOBSON; WILSON, 1992).

WILSON et al. (1996) estudaram se biofilmes de Streptococcus sanguis são susceptíveis a morte por irradiação por luz vermelha de laser após sensibilização por TBO. Também se testou a fototoxicidade desses parâmetros em queratinócitos e fibroblastos. Os microrganismos foram mortos após exposição da luz por 75 segundos na presença de TBO em concentrações de $2,5 \mu \mathrm{g} / \mathrm{mL}$. Já queratinócitos e fibroblastos não perderam a viabilidade quando irradiados por até 2 minutos e expostos ao TBO na concentração de $5 \mu \mathrm{g} / \mathrm{mL}$. Os resultados mostraram que a TFDA pode ser um método possível para tratamento de doença periodontal.

A análise microscópica de estrutura de biofilme dental humano tratada com Zn(II)-phthalocyanine mostrou evidência de destruição após irradiação. Percebeu-se danos consideráveis nas bactérias, vacuolização do citoplasma e dano na membrana celular, mostrando potencial desse tratamento contra biofilme dentário humano (WOOD et al., 1999).

O'Neill et al. (2002) estudaram se biofilme de bactérias orais são susceptíveis a letal fotossensibilização por TBO associado a luz de um laser de Hélio-Neônio. Resultados revelaram morte de $97,4 \%$ das bactérias irradiadas com $31.5 \mathrm{~J}$, na presença de $25 \mu \mathrm{g} / \mathrm{mL}$ de TBO.

Seal et al. (2002) também avaliaram o poder antimicrobiano de TBO associado a luz de laser de Helio-Neônio, mas contra bactérias de um biofilme de Streptococcus intermédia, formado dentro do canal de dentes humanos extraídos. A combinação de TBO a 100 $\mathrm{g} / \mathrm{mL}$ e iluminação por 600s (21 J) levou ao máximo de 
redução das bactérias. Portanto, a terapia fotodinâmica apresentou efeito bactericida, no entanto, não foi hábil para erradicar os microrganismos completamente.

Soukos et al. (2003) investigaram o efeito da TFDA sobre bactérias de biofilme dental natural obtido de pacientes com periodontite crônica, com bolsas de mais de $3 \mathrm{~mm}$ e que não tinham sido tratados nos últimos 3 meses. Utilizou-se como fotossensibilizador uma clorina e6 conjugada a uma poly-I-lisina com 5 resíduos de lisina e um laser de diodo como fonte de luz. A terapia levou a morte de 75 a $80 \%$ das espécies quando a placa foi colocada apenas em PBS e $85-92 \%$, quando foi associado EDTA ao meio. A profundidade do biofilme interfere no resultado, mas a irradiação com luz pulsada aumentou a penetração do fotossensibilizador e a morte dos microrganismos (Soukos et al, 2003).

Biofilme do patógeno oral Actinomyces viscosus foi exposto à luz vermelha, na presença de poli-L-lisina-clorina e6 conjugada (pLCe6). A análise através de microscopia confocal revelou morte de $99 \%$ da espécie bacteriana (SOUKOS et al., 2003).

Para demonstrar o efeito da terapia fotodinâmica antimicrobiana contra Pseudomonas aeruginosa na forma planctônica ou de biofilme, Lee et al. (2004), utilizaram uma protoporfirina IX que pode ser produzido de forma endógena, através da administração de ácido amino levulínico (ALA) e um LED como fonte de luz. Os microrganismos, em ambas as formas, foram inibidos pela terapia, variando a taxa de acordo com as doses utilizadas no tratamento. No caso do biofilme da bactéria houve um novo crescimento um tempo após a aplicação da TFD, o que poderia ser prevenido se ela fosse aplicada duas vezes.

Zanin et al. (2005) também tiveram como resultado decréscimo na viabilidade de $S$. mutans em biofilmes $(99,9 \%)$ após aplicação de TFDA, utilizando como droga fotossensibilizadora o TBO. A fotosensibilização letal ocorre predominantemente nas camadas mais externas, provavelmente pela dificuldade de difusão do fotossensibilizador. Além disso, os resultados mostraram-se dependentes da dose de luz irradiada e biofilmes mais antigos foram menos susceptíveis à TFD.

Experimentos demonstraram que a eritrosina é mais efetiva que Photofrin $^{\circledR}$, que ainda é mais efetivo que azul de metileno como droga fotossensibilizadora na TFD contra biofilme de $S$. mutans, embora todos eles apresentassem propriedades antimicrobianas após a terapia. Assim, concluiu-se que 
aplicar a eritrosina como fotossensibilizador na TFDA mostra excelente potencial para o tratamento da placa. Além disso, demonstrou-se que biofilmes jovens são menos susceptíveis à terapia, já que a efetividade da TFDA aumentou conforme o biofilme apresentava-se com maior tempo de formação (WOOD et al., 2006).

Um outro estudo in vitro avaliando o uso da TFD para bactérias do biofilme dentário combinou o TBO com irradiação com uma luz de laser de diodo vermelha(620-660 nm). A eficácia foi de 95 a 99\% contra os biofilmes contendo Streptococcus mutans, S. sobrinus e S. sanguinis (ZANIN et al., 2006).

Biofilme de Streptococcus intermedius preparado em canais radiculares de dentes humanos extraídos foi submetido à TFDA com TBO e laser diodo (633nm). A fotoativação reduziu significativamente o número de bactérias dos canais (WILLIAMS et al., 2006).

Biofime de Streptococcus mutans foi incubado com eritrosina por 15 minutos e irradiado com luz branca de maneira contínua ou por fracionamento. Houve morte mediada pela TFDA de maneira dose-dependente da luz. O fracionamento mostrou prevenir o fotobranqueamento e reabastecer o oxigênio nos períodos no escuro, o que levou a um aumento da morte celular (METCALF et al., 2006).

Também em 2006, biofilme de S. mutans foi tratado com eritrosina, azul de metileno ou Photofrin ${ }^{\circledR}$ e irradiado com uma lâmpada de filamento de tungstênio. O biofilme foi irradiado até 50 minutos, porém acima de 15 minutos já se percebeu fotobranqueamento dos fotossensibilizadores. Houve redução microbiana com os dois fotossensibilizadores usados, mas a eritrosina foi mais efetiva que o azul de metileno, que ainda foi mais efetivo que Photofrin ${ }^{\circledR}$. Biofilmes jovens foram mais susceptíveis (WOOD et al., 2006).

Giusti et al, em 2006, estudam o efeito antimicrobiano da TFD da descontaminação de dentina cariada induzida artificialmente, em espécimes de dente bovino, utilizando Photogen ${ }^{\circledR}$ como fotossensibilizador e um LED como fonte de luz. Os melhores resultados foram obtidos quando se utilizou Photogen ${ }^{\circledR}$ na concentração de $2 \mathrm{mg} / \mathrm{mL}$ e fotoativação de $24 \mathrm{~J} / \mathrm{cm}^{2}$. Concluiu-se que a terapia utilizando tais parâmetros pode ser efetiva para descontaminação de dentina cariada (GIUSTI et al, 2006).

Soukos et al, em 2006, avaliaram a eficácia da TFDA como coadjuvante no tratamento endodôntico. O corante azul de metileno foi utilizado sozinho e 
associado à luz vermelha sobre cultura de Porphiromonas gengivalis, $P$. intermédia, Fusobacterium nucleatum, Peptostreptococcus micros, Porphiromonas endodontalis e E. faecalis ou dentro de canais de dentes humanos extraídos contaminados com E. faecalis. Quando utilizado isoladamente, esse composto conseguiu eliminar todas as bactérias das espécies Porphiromonas endodontalis e P. intermédia. Houve grande diminuição das outras espécies, com exceção da E. faecalis (apenas $53 \%$ de morte). No entanto, quando se associou a luz, foi possível eliminar 97\% destas. Quando a terapia foi realizada em canais radiculares de dentes extraídos infectados com E. faecalis, formando um biofilme, houve $97 \%$ de redução da viabilidade. Esses resultados demonstraram potencial da terapia no tratamento endodôntico. (SOUKOS et al., 2006).

Hope e Wilson (2006) analisaram a fotosensibilização de biofilme de Streptococcus pyogenes utilizando Sn(iV) clorina e6 (SnCe6) e laser de argônio e Hélio-neônio. Observou-se aumento da permeabilidade da membrana celular após irradiação, portanto a morte celular foi induzida.

Biofilme de Proteus mirabilis e Pseudomonas aeruginosa, preparados em dentes humanos extraídos, foram tratados com um conjugado de polyethylenimine com clorina(e6), e iluminados com um laser diodo (660 nm). A TFD sozinha reduziu os microrganismos em $95 \%$, enquanto quando a técnica foi utilizada em combinação com tratamento endodôntico convencional a redução foi maior que 98\% (GARCEZ et al., 2007).

Müller et al. (2007) estudaram o efeito antimicrobiano do gás ozônio e da TFD contra um biofilme cariogênico multiespécie (Actinomyces naeslundii, Veillonella dispar, Streptococcus sobrinus, S. oralis e Candida albicans) produzido in vitro. $\mathrm{Na}$ TFDA, utilizou-se azul de metileno como fotossensibilizador e um laser de diodo como fonte de luz. Tratamento com clorexidina ou hipoclorito de sódio a $5 \%$ foram utilizados como controle. Somente o hipoclorito foi capaz de eliminar completamente os microrganismos do biofilme. A TFDA e o gás ozônio tiveram efeito mínimo na redução dos microrganismos do biofilme.

A ação fotodinâmica do TBO associado a laser de diodo foi investigada sobre a viabilidade de microrganismos do biofilme de Staphylococcus epidermidis e de Staphylococcus aureus resistentes a penicilina. Foi observada inativação significante das células. $O$ efeito foi dependente da dose de luz. Observaram-se também danos na membrana das células bacterianas após a terapia e rompimento 
da estrutura do biofilme. O tratamento com EDTA seguido pela TFDA aumentou a eficácia para o biofilme de S.epidermidins, mas não para o de S. aureus (SHARMA et al., 2007).

Donnelli et al. (2007) relataram que o uso da droga TBO como agente fotossensibilizador da TFDA é potente contra a Candidose oral. Foi averiguado o efeito da TFDA contra o biofilme de Candida, usando TBO e iluminação com uma lâmpada de Peterson (635nm). Altas concentrações de TBO e longos tempos de incubação foram requeridos para morte total das células.

Fimple et al. (2008) investigaram os efeitos fotodinâmicos do azul de metileno em biofilme muiltiespécies formado por Actinomyces israelii, Fusobacterium nucleatum, Porphiromonas gengivalis, e Prevotella intermédia em canais de dentes humanos infectados experimentalmente. A fotoativação foi realizada com uma luz vermelha de um laser de diodo. A terapia levou a uma redução de $80 \%$ das bactérias. Os autores concluíram que essa terapia pode ser associada a terapia antimicrobiana convencional para tratamento de canais.

Giusti et al. (2008) avaliaram o efeito da TFDA na descontaminação de dentina bovina cariada utilizando dois fotossensibilizadores, Photogen ${ }^{\circledR}$ e TBO, e a luz vermelha de um LED como fonte de luz. A cárie foi induzida em espécimes obtidos de dente bovino e a terapia foi aplicada. O uso do LED associado aos dois fotossensibilizadores foi efetivo na redução bacteriana e os melhores efeitos contra S. mutans e $L$. acidophilus foram obtidos com TBO $0,1 \mathrm{mg} / \mathrm{mL}$ e a dose de luz de $48 \mathrm{~J} / \mathrm{cm}^{2}$. Também se observou que a toxicidade do fotossensibilizador sem ativação por luz é maior para o TBO.

A TFDA foi testada em associação à terapia convencional para desinfecção de canais radiculares em pacientes. Utilizou-se como fotossensibilizador polietilenemina (PEI) conjugado com clorina e6 (ce6) e a fonte de luz foi um laser de diodo com fibra óptica acoplada, capaz de chegarnaà porção apical no canal. Os canais foram preparados pela técnica coroa-ápice. O canal foi irrigado com hipoclorito de sódio a 2,5\%, seguido por peróxido de hidrogênio a $3 \%$ entre cada lima. No final do procedimento, foi irrigado com solução salina estéril e procedeu-se a secagem com pontas de papéis estéreis (utilizadas para amostra microbiológica). Em seguida, a TFD foi realizada, colocando-se a solução do fotossensibilizador dentro do canal $(0,5 \mathrm{~mL})$. Esperou-se 2 minutos (tempo de pré-irradiação) e em seguida, o canal foi irradiado com a fibra óptica. Cones de papel foram utilizados 
para secar e como amostra microbiológica. Utilizou-se como curativo uma pasta de hidróxido de cálcio e restaurou-se provisoriamente com IRM. Na visita subseqüente, analisou-se clinicamente e o procedimento foi repetido (instrumentação + TFDA). Em seguida, obturou-se com cimento Sealer 26 e restaurou-se o dente. Após a terapia inicial, observou-se redução dos microrganismos de 91\%. Após a TFDA, essa redução aumentou para $98,5 \%$. Percebeu-se recolonização de $40 \%$ após uma semana. Depois da segunda etapa de terapia convencional, a redução foi praticamente a mesma da primeira fase (92\%) e a segunda etapa de TFDA elevou 0 índice de redução para 99,9\%. Assim, percebeu-se que a TFDA associada ao tratamento convencional foi efetiva na redução microbiana em dentes humanos infectados (GARCEZ et al., 2008).

Avaliou-se o efeito da TFDA na inativação de diversas espécies de Candida albicans e Candida glabrata resistentes ou não ao fluconazol na forma planctônica ou de biofilme. Associou-se o fotossensibilizador Photogem ${ }^{\circledR}$ com a irradiação por LED. As espécies na forma planctônica foram mortas efetivamente, mas o resultado variou entre as espécies. Houve também decréscimo significante na viabilidade do biofilme de três espécies de $C$. albicans e duas espécies de $C$. glabrata. Esses resultados demonstraram que apesar da TFDA ser feita contra espécies de Candida, aquelas resistentes ao fluconazol são menos susceptíveis. Além disso, as espécies na forma de biofilme também são menos sensíveis que suas formas em cultura planctônica. (DOBIGO et al., 2009).

Biofilme de Staphilococcus aureus foi submetido à TFDA combinada ou não a quimioterapia ou fagocitose, para avaliação do papel antimicrobiano. Foi observada redução significante da sobrevivência bacteriana do biofilme quando este foi exposto à porfirina catiônica tetra-substituted N-methyl-pyridyl-porphine (TMP) e irradiado por uma luz visível. Os efeitos variaram conforme o estágio de maturação e desenvolvimento do biofilme, sendo aqueles mais jovens, mais susceptíveis. Além disso, os biofilmes pré-tratados com vancomicina (antibiótico) ou submetidos à ação fagocítica por células sanguíneas foram quase erradicados completamente. Portanto, a combinação de tratamentos pode ser positiva para inativação desse tipo de biofilme (SBARRA et al., 2009).

Estudou-se o papel da TFDA em dentina humana cariada produzida in situ. Voluntários utilizaram um dispositivo intrapalatino contendo espécimes dentais de dentina durante 20 dias, submetendo tais espécimes ao desafio cariogênico 
(solução de sacarose $40 \%$ ) durante 10 vezes ao dia. Depois disso foi analisado o efeito antimicrobiano da terapia utilizando TBO como corante fotossensibilizador e irradiação por LED (47 ou $94 \mathrm{~J} / \mathrm{cm}^{2}$ ). Analisou-se os efeitos sobre microrganismos totais, contra estreptococos, contra $S$. mutans e contra lactobacilos. Observou-se redução microbiana com ambas as doses de luz. Portanto a terapia foi efetiva para descontaminação de dentina cariada produzida in situ, podendo ser uma técnica útil para descontaminação da de cavidades cariosas, anteriormente à restauração (LIMA et al., 2009).

Oliveira et al. (2009) investigaram o nível de citocinas (TNF-a e RANKL) do fluido crevicular cervical de pacientes com periodontite agressiva, após tratamento com TFDA ou raspagem pericoronária manual. Nenhum dos tipos de tratamento resultou em redução nos níveis de TNF- $\alpha$ após 30 dias de tratamento. Os níveis de TNF- $\alpha$ e RANKL foram parecidos em diversos tempos analisados, mostrando que os dois tipos de tratamento têm similares efeitos no nível de citocinas do fluido crevicular em pacientes com periodontite agressiva.

Junqueira et al. (2009) avaliaram os efeitos TFDA sobre candidose bucal em ratos. A candidose foi induzida no dorso da língua dos animais, azul de metileno foi utilizado como fotossensibilizador e laser como fonte de luz. Os ratos foram sacrificados imediatamente, um, três ou cinco dias após o tratamento, para análise microscópica do dorso da língua. Observou-se que os grupos tratados com a terapia mostraram menos alterações epiteliais e menos sinais de inflamação crônica comparado aos grupos controle.

Pinheiro et al. (2009) estudaram o efeito da TFDA na descontaminação do canal radicular de dentes decíduos humanos associado ao tratamento convencional. Utilizou-se TBO como agente fotossensibilizador, levado ao canal com cone de papel. A instrumentação convencional levou a uma redução de $82,59 \%$ das bactérias viáveis. Depois de TFDA essa redução subiu para 98,37\%. Assim, é uma terapia efetiva como coadjuvante no tratamento endodôntico convencional de dentes decíduos.

Em 2010, Mima et al. avaliaram a efetividade da TFD antimicrobiana em modelos animais de candidose oral utilizando uma porfirina $\left(\right.$ Photogen $^{\circledR}$ ) como fotossensibilizador e um LED como fonte de luz. Ratos foram imunossuprimidos e contaminados oralmente com $C$. albicans. Quatro dias após, a TFDA foi aplicada no dorso da língua. $O$ animal foi, então, sacrificado, o número de leveduras 
sobreviventes foi contado e fez-se histologia do tecido da língua para determinação da presença de fungo e estado inflamatório. A terapia resultou em redução significante de $C$. albicans comparando-se ao controle (sem tratamento). A avaliação histológica revelou que a terapia não causou efeitos adversos significantes na mucosa lingual.

Um recente estudo demonstrou que três importantes periodontopatógenos (Porphyromonas gingivalis, Fusobacterium nucleatum, e Aggregatibacter actinomycetemcomitans) são susceptíveis a morte mediada por PDT quando na forma planctônica ou na forma de biofilme de maneira dose dependente da luz. Para a sensibilização das células foi utilizado o corante azul de metileno e a irradiação foi feita com um laser de diodo. A dose de energia capaz de erradicar os microrganismos de ambas as formas foi de $9,4 \mathrm{~J} / \mathrm{cm}^{2}$. (STREET et al., 2010).

Goulart et al. (2010) testaram a eficácia da TFDA utilizando azul de metileno ou eritrosina para inativar Aggregatibacter actinomycetemcomitans, o principal patógeno na doença periodontal, na forma planctônica ou de biofilme. A fonte de luz utilizada foi um fotopolimerizador de resinas. Os resultados mostraram que a eritrosina é mais eficiente na morte das bactérias na forma planctônica $(75 \%)$ e biofilme (77\%), comparada ao azul de Metileno (50\% para planctônico e 54\% para biofilme). Portanto, a TFDA utilizando esses fotossensibilizadores associados à irradiação por luz de fotopolimerizador poderia se uma terapia eficiente para descontaminação de bolsas periodontais em pacientes com periodontite agressiva.

A TFDA sobre biofilme de Pseudomonas aeruginosa selvagem ou uma espécie mutante foi avaliada utilizando-se uma porfirina catiônica $(5,10,15,20$ tetrakis(1-methylpyridino)- $21 \mathrm{H}, 23 \mathrm{H}$-porphine, tetra-p-tosylate salt - TMP) como fotossensibilizador e uma lâmpada de vapor de mercúrio de 100W equipada com um filtro para refletir luz colorida. A TFDA utilizando TMP na concentração de $100 \mu \mathrm{M}$ levou à morte de uma boa parte de ambas as espécies de bactérias em biofilmes, no entanto com pouca ruptura da matriz do biofilme. A exposição à concentração de $225 \mu \mathrm{M}$ resultou em morte quase completa e separação do biofilme de células selvagens. No entanto, o biofilme formado com as espécies mutantes, que contém menos DNA extracelular, permaneceu intacto. A redução na viabilidade foi de 1log10 para o biofilme de espécie selvagem e 3.9-log10 para o outro tipo. Assim a 
TFDA atua como morte direta de cada célula e destruição do biofilme e seus substratos (COLLINS et al., 2010). 
Proposicão 

2 PROPOSIÇÃO

O objetivo deste estudo foi verificar o efeito antimicrobiano da clorofila liquida (CL) e do azul de Toluidina $\mathrm{O}$ (TBO) quando utilizados como corantes fotossensibilizadores sobre placa bacteriana humana formada in situ, por meio da TFDA através da ação de fonte de luz laser, comparando aos efeitos da clorexidina.

Objetivos gerais

- Avaliar a ação antimicrobiana da TFDA e da clorexidina sobre biofilme dentário humana.

Objetivos específicos

- Avaliar o efeito antimicrobiano da clorexidina 0,5\% sobre biofilme dentário humano.

- Avaliar o efeito antimicrobiano da TFDA com o uso dos fotossensibilizadores TBO e CL sobre biofilme dentário humano, utilizando o laser como fonte de luz.

- Comparar o efeito antimicrobiano da TFDA com a Clorexidina 
Material e Métodos 



\section{MATERIAL E MÉTODOS}

\subsection{Aspectos éticos}

O presente estudo foi aprovado pelo Comitê de Ética em pesquisa da Faculdade de Odontologia de Bauru - USP através do processo 144/2008.

\subsection{Delineamento experimental}

Este estudo in situ envolveu um desenho aleatorizado em blocos e foi realizado em um período de 2 dias, durante os quais os voluntários utilizaram dispositivos intrabucais palatinos contendo 7 espécimes constituídos blocos de esmalte.

Foi usado um substrato dentário - dente bovino, sob desafio cariogênico, acumulando biofilme dentário. O total de espécimes de blocos de esmalte bovino foram aleatoriamente divididos entre os voluntários.

Após o período experimental in situ (2 dias), o biofilme dentário foi analisado. Dos 7 espécimes de cada dispositivo, 1 fez parte do grupo controle sem tratamento, os outros receberam terapias antimicrobianas (Clorexidina 0,5\%, Laser, TBO, TBO + Laser, CL, CL + Laser). Em seguida o biofilme foi cuidadosamente coletado e pesado. Foram realizadas diluições seriadas, plaqueamento em placas de Petri e as Unidades Formadoras de Colônias (UFS) foram contadas. Para analisar a viabilidade dos microrganismos, as amostras foram coradas com Laranja de Acridina que evidencia a viabilidade celular e em seguida, observadas em microscópio de fluorescência.

\subsection{Seleção dos voluntários}

Oito voluntários adultos de 18 a 30 anos, com 28 dentes na boca, foram selecionados para participar da pesquisa. Os critérios de exclusão considerados na anamnese para composição da amostra foram: hábito de fumar; apresentar doença periodontal ou lesões de cárie ativa no estágio de cavitação; apresentar desgaste dentário acentuado; ter recebido aplicação tópica de flúor gel pelo menos duas semanas antes do estudo; ter utilizado nos últimos 2 meses ou utilizar medicamentos que afetam o fluxo salivar (antidepressivos, narcóticos, diuréticos ou anti-histamínicos); ter sofrido irradiação ou quimioterapia; apresentar doenças 
sistêmicas tais como as auto-imunes, xerostomia, menopausa, diabetes tipo 1, má nutrição, problemas gastro-esofágicos e distúrbios de regurgitação e vômito e utilizar ferro para tratamento de anemia.

\subsection{Preparo dos espécimes de esmalte}

\subsubsection{Obtenção de dentes bovinos}

Dentes incisivos bovinos extraídos de gado da raça Nelore com idade média de 36 meses, abatidos para consumo no Frigorífico Vangélio Mondelli Ltda, em Bauru, SP foram utilizados no presente estudo. Os incisivos foram limpos com curetas periodontais para remover todo e qualquer resíduo de tecido gengival aderido à superfície dentária do dente bovino e posteriormente esterilizados em solução de formol a 2\%, pH 7,0 (Departamento de Bioquímica da Faculdade de Odontologia de Bauru- USP), preparado com tampão fosfato, onde ficaram imersos durante todo o período de preparo dos espécimes de esmalte.

\subsubsection{Obtenção dos espécimes de esmalte bovino}

Os dentes passaram por uma seleção prévia, a olho nu, a fim de se eliminar os que apresentavam trincas, rachaduras, manchas hipoplásicas ou grande desgaste incisal. Primeiramente foram removidas as raízes, com o auxílio de um torno de polimento odontológico adaptado para corte e um disco diamantado Diaflex$F$, sendo feita uma secção na porção cervical dos dentes. Para este corte, não houve necessidade de fixação prévia do incisivo, bastando que o elemento dentário fosse firmemente segurado pela porção coronal e pela raiz, sendo levado manualmente de encontro ao disco adaptado na máquina de corte.

Em seguida, as coroas foram fixadas com godiva termoativada no canto inferior direito de uma pequena placa de acrílico cristal (40 X $40 \times 5 \mathrm{~mm})$, para facilitar adaptação na máquina de corte. A placa de acrílico foi acoplada em um aparelho de corte de precisão Osomet Low Speed Saw e com o auxílio de dois discos diamantados dupla face e um espaçador de aço inoxidável $(7 \mathrm{~cm}$ de diâmetro, $4 \mathrm{~mm}$ de espessura e orifício central de $1,3 \mathrm{~cm}$ ) entre os discos com velocidade de 300rpm, refrigerado com água deionizada, foram obtidos os espécimes de esmalte de $4 \times 4 \mathrm{~mm}$ da porção mais plana da coroa, através de uma secção dupla no sentido cérvico-incisal e outra no sentido mésio-distal. Nova seleção foi realizada 
após esses cortes e, os fragmentos com esmalte trincado ou manchado foram desprezados.

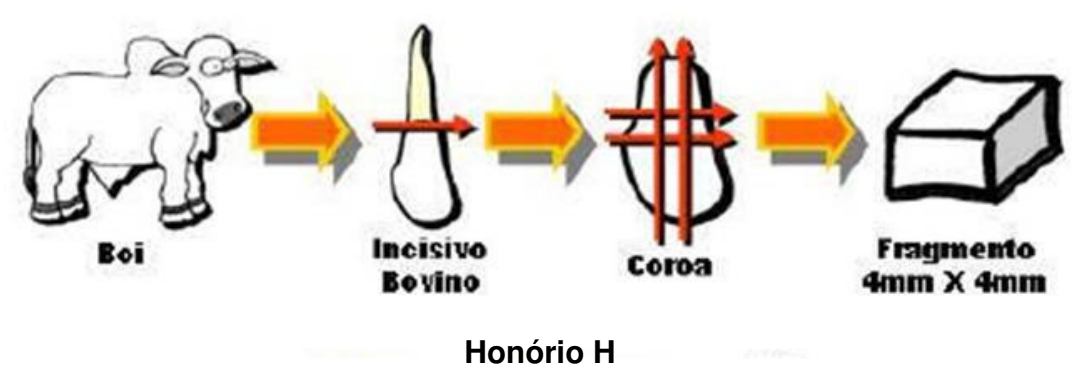

Figura 1: Obtenção dos espécimes bovinos
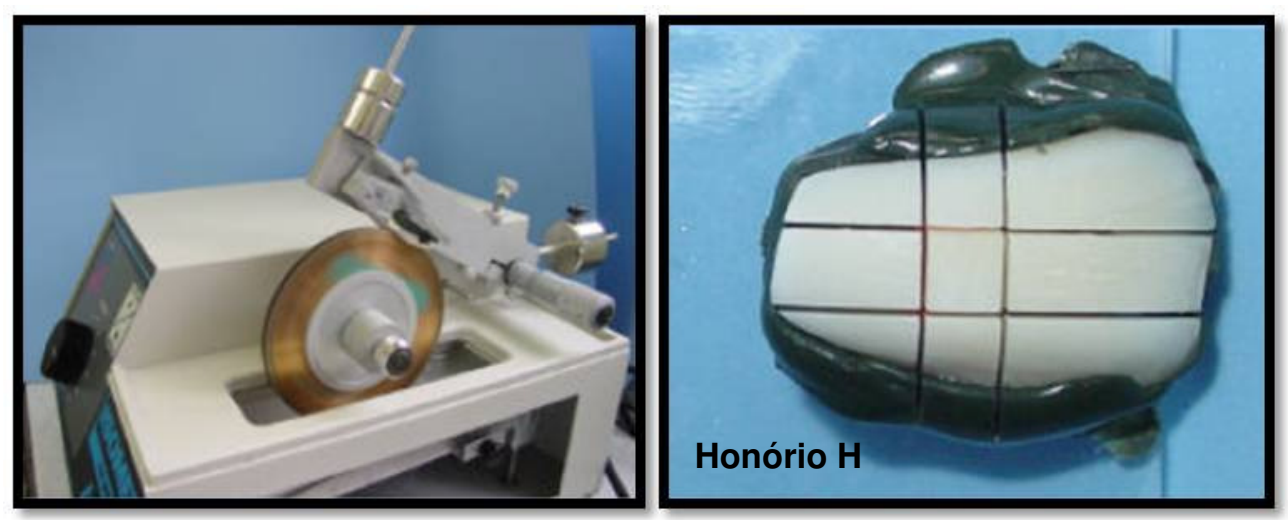

Figura 2: Maquina de corte e fragmento seccionado

\subsubsection{Planificação e polimento dos espécimes de esmalte humano}

Com o intuito de realizar a planificação da dentina, os fragmentos foram posicionados no centro de um disco acrílico cristal $(30 \mathrm{~mm}$ de diâmetro por $8 \mathrm{~mm}$ de espessura), com a maior área plana de esmalte voltada para o disco e com auxílio de um instrumento PKT e uma lamparina foram fixadas colocando-se cera pegajosa ao redor do espécime. Cuidado especial foi tomado para que a cera não fluísse entre o esmalte e o acrílico. O conjunto (disco/dente) foi adaptado em uma Politriz Metalográfica (APL 4, Arotec, Cotia, SP), com sistema de polimento, múltiplo, capaz de realizar o polimento automático de 6 corpos de prova (Figura 3), permitindo 0 paralelismo entre as superfícies polidas e a base do acrílico onde são fixados os espécimes. Neste procedimento de planificação, foi utilizada uma lixa de silicone carbide de granulação 320 , com refrigeração de água deionizada, até que os 
fragmentos ficassem com espessura de aproximadamente $4 \mathrm{~mm}$. Assim, a politriz foi acionada em baixa velocidade, com 2 pesos padrões de $86 \mathrm{~g}$, durante 30 segundos a 2 minutos. $O$ tempo não pode ser exatamente especificado porque com o uso, a lixa se desgasta e foi necessário mais tempo para que se alcance a espessura desejada.

Em seguida, os dentes foram removidos, e a dentina foi colocada em contato com o disco acrílico, fixando-se o dente, de modo que o esmalte pudesse ser planificado. Procedimento semelhante ao da dentina foi realizado agora com 0 esmalte.

A partir do início dos procedimentos de planificação e polimento, os espécimes passaram a ser guardados em refrigerador a aproximadamente $4^{\circ} \mathrm{C}$. Permaneceram armazenados em recipientes plásticos com tampa, separados por folha de papel absorvente embebidos em água deionizada.

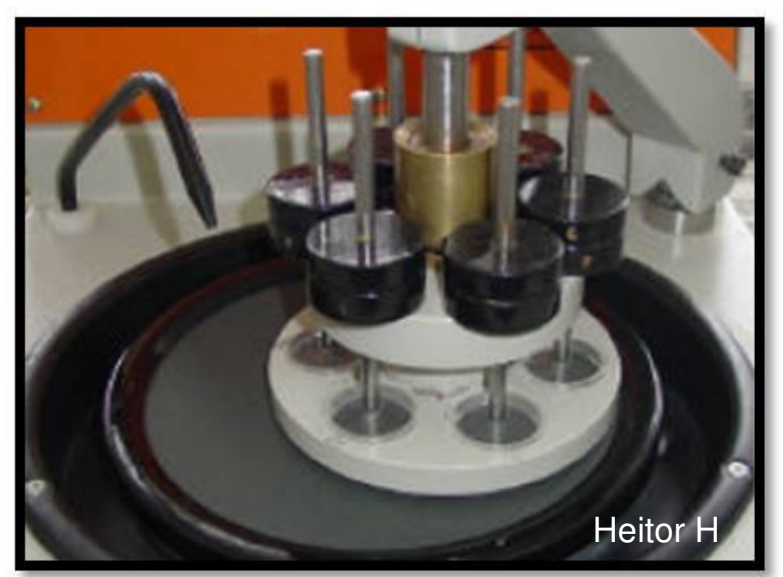

Figura 3: Politriz metalográfica

\subsection{Preparo do dispositivo intrabucal palatino}

Moldes do arco superior dos voluntários foram obtidos com alginato e vazados modelos em gesso pedra. Dispositivos intrabucais palatinos foram confeccionados em resina acrílica. Cada dispositivo continha duas fileiras verticais consecutivas, uma no lado direito e outra no esquerdo, com 4 cavidades de $5 \times 5 \times 4$ $\mathrm{mm}$, sendo que cada uma delas serviu para fixação de um espécime, com cera pegajosa. Os dispositivos foram polidos mecanicamente no torno com pedra-pomes e quimicamente, pela imersão, por 5 segundos, em monômero de resina acrílica aquecido.

Os espécimes foram fixados ao nível da superfície de resina do aparelho, evitando-se fendas laterais entre os blocos e as cavidades, o que possibilitaria 
acúmulo indesejável de biofilme dentário. Esses espécimes foram fixados $1 \mathrm{~mm}$ abaixo do nível do dispositivo palatino para que o biofilme fosse formado sobre os blocos de dente. A placa dentária formada foi protegida de distúrbios mecânicos por uma tela plástica fixada na superfície do acrílico. Tal dispositivo pode ser observado na Figura 4.

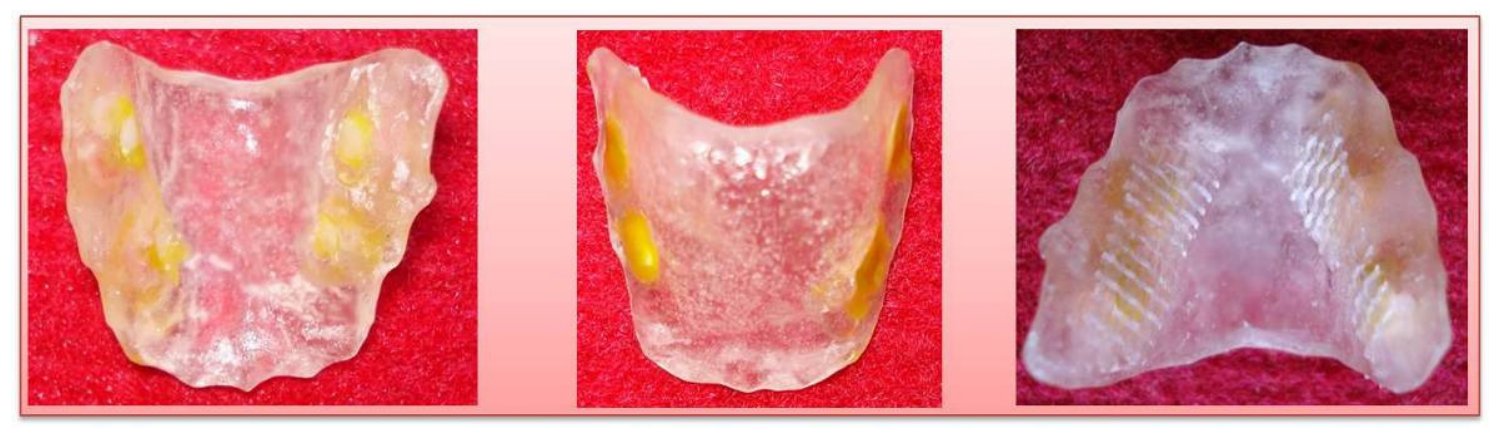

Figura 4: dispositivo intrapalatino

\subsection{Procedimentos intrabucais}

Alguns dias antes do período experimental, cada voluntário recebeu uma pasta com uma lista de instruções, um estojo plástico para guardar o dispositivo intrabucal, um frasco de solução de sacarose $20 \%$ para ser gotejada nos espécimes, porções de gaze, escova dental, fio dental e dentifrício para realização da higiene bucal.

Cada voluntário utilizou o dispositivo intrabucal durante 2 dias. $\mathrm{O}$ aparelho foi instalado um dia antes do início do período experimental, à noite, após a última escovação dentária, para permitir a formação da película adquirida. Eles foram orientado a utilizar o dispositivo intrabucal continuamente $(24 \mathrm{~h} / \mathrm{dia})$ exceto durante as refeições (3 horas por dia), sendo que nestes períodos os dispositivos foram mantidos no estojo plástico, envolto em gaze umedecida em água de abastecimento (Bauru - 0,7 ppm F). Foi permitida a realização da higiene bucal normalmente, após as refeições, sem o dispositivo. Foi permitido também limpar o dispositivo com escova dental, sendo proibida a escovação da área que contiver os espécimes. Os voluntários também foram orientados a não ingerirem bebidas, exceto água, durante o experimento, a não ser nos horários das refeições quando não estavam utilizando o dispositivo. Além disso, orientou-se que se gotejasse uma solução de sacarose fresca a $20 \%$ sobre todos os blocos, 8 vezes ao dia, e 
após 5 minutos que recolocassem o dispositivo na boca. $O$ intervalo entre cada gotejamento foi de no mínimo 1 hora.

\subsection{Terapias aplicadas aos espécimes}

Após os 2 dias, cada espécime recebeu um tipo de tratamento de acordo com os seguintes grupos:

1) Grupo controle: não recebeu nenhum tipo de tratamento. Foi apenas gotejada $25 \mu \mathrm{L}$ de água destilada sobre o dente, para mimetizar uma possível lavagem das outras soluções. Esperou-se 5 minutos.

2) Grupo Laser: gotejou-se $25 \mu \mathrm{L}$ de água destilada sobre o dente, com o mesmo objetivo citado no grupo anterior. Esperou-se 5 minutos e, em seguida, procedeu-se a irradiação do espécime com o Laser a uma potência de $40 \mathrm{~J} / \mathrm{c}^{\mathrm{m} 2}$, o mais próximo possível do espécime.

3) Grupo Clorexidina: gotejou-se $25 \mu \mathrm{L}$ da solução aquosa de clorexidina $0,5 \%$. Esperou-se 5minutos

4) Grupo TBO: gotejou-se $25 \mu \mathrm{L}$ da solução $100 \mu \mathrm{g} / \mathrm{mL}$ de TBO diluído em água destilada estéril. Esperou-se 5 minutos.

5) Grupo TBO: gotejou-se $25 \mu \mathrm{L}$ da solução $100 \mu \mathrm{g} / \mathrm{mL}$ de TBO, esperou-se 5 minutos e, em seguida, procedeu-se a irradiação do espécime com o Laser a uma potência de $40 \mathrm{~J} / \mathrm{cm}^{2}$, o mais próximo possível do espécime.

6) Grupo CL: gotejou-se $25 \mu \mathrm{L}$ da solução $100 \mu \mathrm{g} / \mathrm{mL}$ de $\mathrm{CL}$ diluída em éter. Esperou-se 5minutos.

7) Grupo CL: gotejou-se $25 \mu \mathrm{L}$ da solução $100 \mu \mathrm{g} / \mathrm{mL}$ de $\mathrm{CL}$ diluída em éter, esperou-se 5 minutos e, em seguida, procedeu-se a irradiação do espécime com o Laser a uma potência de $40 \mathrm{~J} / \mathrm{cm}^{2}$, o mais próximo possível do espécime.

A fonte de luz utilizada foi o LASER HAND ${ }^{\circledR} /$ MM Optics Ltda (Figura 5). Este é um laser de diodo de baixa intensidade no intervalo espectral do visível (660nm), sendo utilizado como coadjuvante em vários tratamentos terapêuticos em Odontologia, Medicina e Fisioterapia. Este aparelho emite luz apenas na faixa espectral prevista e potência calibrada, faixa esta que está no espectro de absorção 
dos corantes que foram utilizados. Ele apresenta potência de $40 \mathrm{~mW}$ e a dosagem de aplicação escolhida foi de $30 \mathrm{~J} / \mathrm{cm}^{2}$.

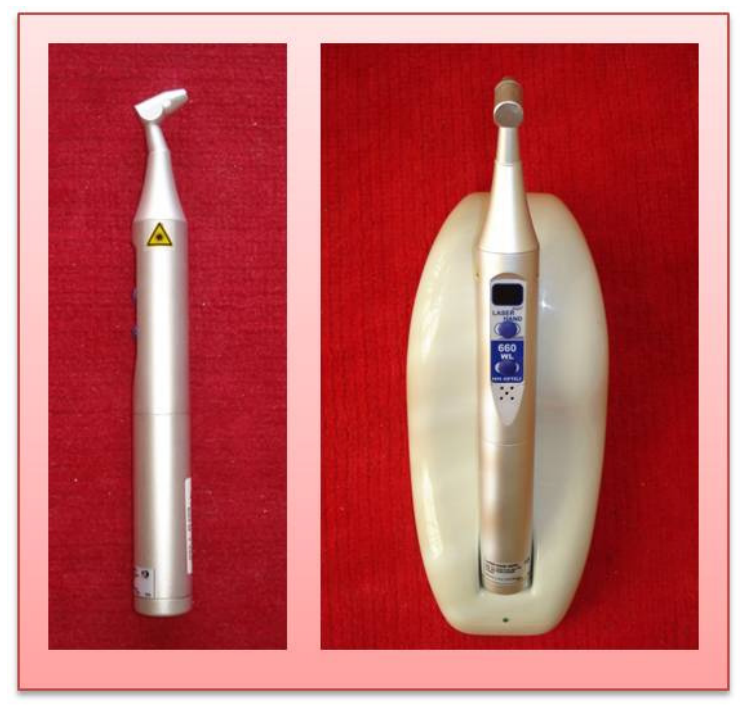

Figura 5: LASER HAND ${ }^{\circledR}, 660 \mathrm{WL}$, MM Optics Ltda

Para coleta da placa, a tela plástica que cobre os espécimes foi retirada e o biofilme foi removido através de raspagem com cureta periodontal do tipo Gracey e colocados em microtubos envoltos com papel alumínio (para evitar exposição à luz ambiente), previamente pesados, contendo $2 \mathrm{~mL}$ de solução fisiológica e bolinhas de vidro. Em seguida, os tubos foram novamente pesados, valor que foi subtraído do peso do tubo anterior, para se avaliar a quantidade de biofilme recolhida.

\subsection{Processamento das amostras}

Os microtubos foram agitados mecanicamente, em Vortex, por 5 minutos para dispersão do biofilme. Em seguida, as amostras foram colocadas em tubos "eppendorf" e promoveu-se o isolamento dos microrganismos do meio de cultura através de centrifugação por 5 minutos a $600 \mathrm{~g}$. O pellet obtido foi diluído em $1 \mathrm{ml}$ de PBS EDTA (para facilitar a dispersão das células), agitado mecanicamente por 3 minutos para suspensão do material e encaminhado para novo ciclo de centrifugação. Esse procedimento foi repetido por três vezes. A execução desta etapa objetivou, além da dispersão do biofilme, a lavagem do material para remoção de impurezas e resquícios de meio de cultura. O pellet final obtido foi diluído em 500 $\mu \mathrm{L}$ de PBS 1X. Em seguida, o pellet foi novamente ressuspendido através de agitador mecânico por 3minutos e os tubos de "ependorff" envoltos em papel alumínio para proteção contra luz ambiente. 


\subsection{Análise Microbiológica}

Uma alíquota da solução homogeneizada foi diluída em série na ordem de $10^{1}$ a $10^{4}$, em soro fisiológico estéril e inoculado em meios de cultura em placas de Petri. Alíquotas das diluições $10^{3}$ e $10^{4}$ foram semeadas na superfície de Agar Brain Heart Infusion (BHI), para a determinação do total dos microrganismos viáveis. Alíquotas das diluições $10^{3}$ e $10^{4}$ também foram semeadas em meio Ágar Mitis Salivarius (MS) (Difco) para determinação do número total de estreptococos. Alíquotas da solução sem diluição ou na diluição $10^{1}$ foram semeadas em meio Agar SB20 acrescido de bacitracina (GOLD; JORDAN; VAN HOUTE, 1973) para determinação da população de estreptococos do grupo mutans. Para a verificação da presença de lactobacilos (LB), alíquotas sem diluição foram inoculadas em meio Ágar Rogosa SL (Difco). Para contagem do número de Candida albicans, alíquotas das amostras sem diluição foram inoculadas em meio Agar Sabouraud. Alíquotas de $25 \mu \mathrm{l}$ de cada diluição foram semeadas na superfície de agar e espalhadas com o auxílio de uma alça de Drigalski.

As placas de BHI e Agar Sabouraud foram incubadas em $10 \%$ de $\mathrm{CO}_{2}$ (estufa de $\mathrm{CO}_{2}$ Shel Lab, mod. 2123, Oregon, EUA), a $37^{\circ} \mathrm{C}$, por 48 horas. As placas de Ágar Mitis Salivarius, Ágar Rogosa e SB20 foram incubadas em câmara de anaerobiose (PLAS by LABS, LANSING, MICH., USA) a $37^{\circ} \mathrm{C}$ por 48 horas.

Após a incubação, foi realizada a contagem das colônias características em cada placa, observadas com auxílio de microscópio estereoscópico com aumento de dez vezes, na diluição que apresentou entre 30 e 300 colônias por placa. Os procedimentos foram realizados em duplicata e a média das contagens foi calculada. Os resultados estão expressos em UFC/g de biofilme coletado.

\subsection{Microscopia de fluorescência}

\subsubsection{Processamento das amostras para microscopia}

Uma alíquota $(100 \mu \mathrm{L})$ de cada amostra foi imediatamente processada para análise em microscopia de fluorescência. A marcação foi realizada com Laranja de Acridina 10\%.

Adicionou-se $1 \mu \mathrm{L}$ do corante para cada alíquota. Incubou-se durante 15 minutos em estufa a $37^{\circ} \mathrm{C}$. Em seguida, adicionou-se $1 \mathrm{~mL}$ de PBS, centrifugou-se 
por $5 \mathrm{~min}$ a 500G. Dispensou-se o sobrenadante, acrescentou-se $100 \mu \mathrm{L}$ de PBS $1 \mathrm{X}$ estéril, homogeinizou-se a amostra e montou-se a lâmina para microscopia. Sobre uma lâmina limpa, pingou-se $25 \mu \mathrm{L}$ da amostra. Sobre o líquido, foi colocada uma lamínula e o conteúdo foi isolado com esmalte de unha.

\subsubsection{Análise em Microscopia de fluorêscencia}

Imediatamente após a montagem das lâminas, as amostras foram examinadas utlizando um microscópio confocal Leica TCS-SPE (Leica Microsystems $\mathrm{GmbH}$, Mannhem, Alemanha). Os espécimes foram observados utilizando a lente de 63 vezes, com óleo de imersão. Foram capturadas três imagens (através do programa Leica Apllication Suite-Advanced Fluorescence software - LAS AF, Leica Mannheim, Alemanha), escolhidas aleatoriamente, para a contagem de microrganismos viáveis e não viáveis. As imagens objetivaram a contagem da porcentagem de microrganismos viáveis (corados em vermelho/laranja) ou inviáveis (corados em verde). A contagem foi realizada pela análise da \% de cor verde ou vermelha/laranja em cada campo com o auxílio do programa BiolmageL (Image analysis software for investigation of microbial biofilms)

\section{11 Análise Estatística}

Os dados numéricos da UFC/g foram analisados estatisticamente para determinar se existe diferença entre os grupos testes e grupos controles, utilizandose $o$ teste $t$ de Student. Para estabelecer se existe diferença entre os diferentes grupos experimentais o teste a ser utilizado foi o de análise de variância one-way ANOVA. Todas as médias dos dados \pm erros padrões das médias foram comparados entre si e em relação ao grupo controle e os valores foram considerados significantes quando $p<0,05$. 
Resultados 



\section{RESULTADOS}

\subsection{Contagem dos microrganismos totais}

O plaqueamento realizado nas placas de cultura contendo $\mathrm{BHI}$ possibilitou a análise da quantidade de microrganismos totais recuperados do biofilme dentário de cada grupo. As UFC foram contadas após 48 horas de incubação em estufa a $37^{\circ} \mathrm{C}$ e foram calculadas em relação a quantidade de biofilme plaqueado. Foi possível realizar contagem nas diluições de $10^{3}$ e $10^{4}$. Diluições abaixo dessas mostraram crescimento exagerado, não sendo possível contagem e diluições de $10^{5}$ e $10^{6}$ não permitiram observar crescimento. Os resultados obtidos são expressos em UFC/g, podem ser observados na Figura 6 e estão descritos no Gráfico/ Tabela 1.

Após análise estatística, adotando nível de significância 0,05\%, pelo teste de variância one-way ANOVA, para comparação entre grupos, não foi possível perceber diferença significante entre os grupos. Através do teste t de Student, que compara o grupo controle negativo com os outros grupos, notou-se diferença estatística entre o grupo controle e o grupo tratado com clorexidina.

No entanto, é possível perceber uma tendência de diminuição do número de bactérias crescidas em todos os grupos testes, ao se comparar com o grupo controle, o que é mais fácil de visualizar na Tabela/Gráfico 2, que mostram a porcentagem de redução em relação ao grupo controle negativo (sem tratamento).

A redução bacteriana mais evidente foi percebida no grupo tratado com clorexidina, resultado esperado, já que é ela é uma substância tradicionalmente usada como agente antimicrobiano, com diversos estudos mostrando tal propriedade.

Quando a luz foi aplicada isoladamente (sem a presença do fotossensibilizador), foi possível se observar uma sensível diminuição no número de bactérias. No entanto, dentre todos os tratamentos, esse foi o menos efetivo na morte dos microrganismos.

Ao se utilizar somente o corante TBO na concentração $100 \mu \mathrm{g} / \mathrm{mL}$ como tratamento, percebeu-se uma redução microbiana maior que a observada quando somente a luz laser foi utilizada. No entanto, a TFDA com este corante (TBO na mesma concentração associado à irradiação pelo Laser $-30 \mathrm{~J} / \mathrm{cm}^{2}$ ), levou a uma quantidade menor de morte dos microrganismos. 
Com o corante $\mathrm{CL}$, também se percebeu redução microbiana quando este foi utilizado sem a incidência e luz como tratamento. No entanto, tal redução aumentou com a irradiação pela fonte de luz..

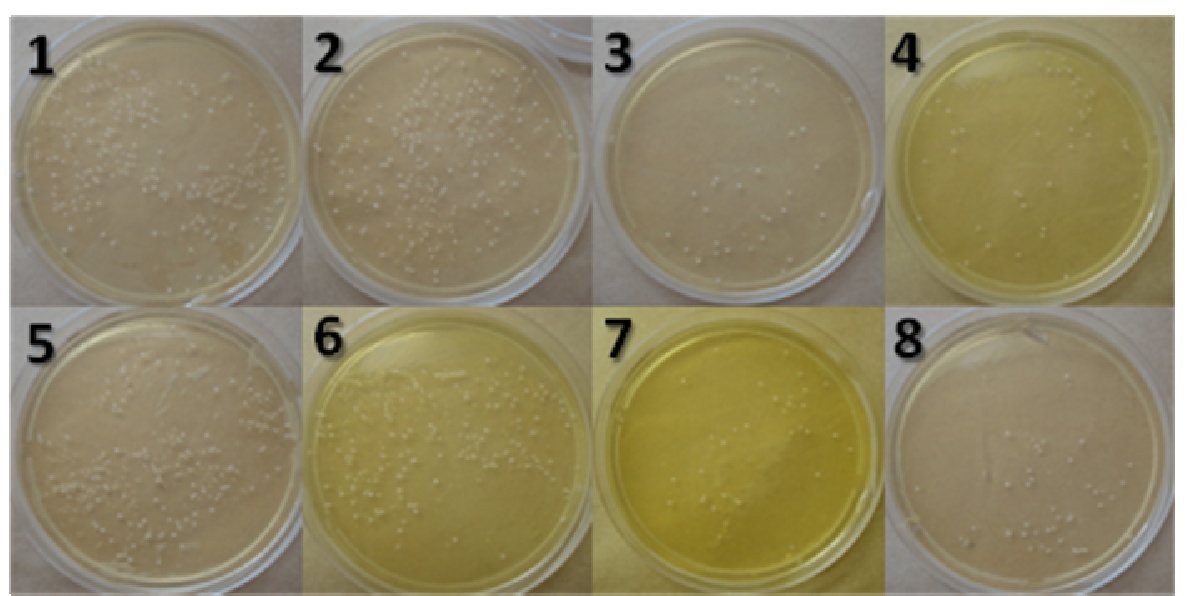

Figura 6: Plaqueamento de amostras dos oito grupos de um paciente em meio $\mathrm{BHI}$, na diluição $10^{4}$, após $48 \mathrm{~h}$ em estufa a $37^{\circ} \mathrm{C}$

\begin{tabular}{|l|c|c|c|c|}
\hline \multicolumn{4}{|c|}{ Microrganismos totais (UFC/g) } \\
\hline GRUPO & Controle & Laser & CLX & CLX + Laser \\
\hline & $1,5 \times 10^{9} \pm 2 \times 10^{9}$ & $1,1 \times 10^{9} \pm 2,8 \times 10^{9}$ & $1,6 \times 10^{8} \pm 2 \times 10^{9}$ & $1,5 \times 10^{9} \pm 3,3 \times 10^{9}$ \\
\hline GRUPO & TBO & TFD TBO & CL & TFD CL \\
\hline & $6,1 \times 10^{8} \pm 1,1 \times 10^{9}$ & $1,2 \times 10^{9} \pm 2 \times 10^{9}$ & $4,7 \times 10^{8} \pm 4,2 \times 10^{8}$ & $9,7 \times 10^{8} \pm 2,2 \times 10^{9}$ \\
\hline
\end{tabular}

Tabela1: Contagem dos microrganismos totais (UFC por grama de biofilme) \pm desvio padrão, após plaqueamento e incubação por 48horas 


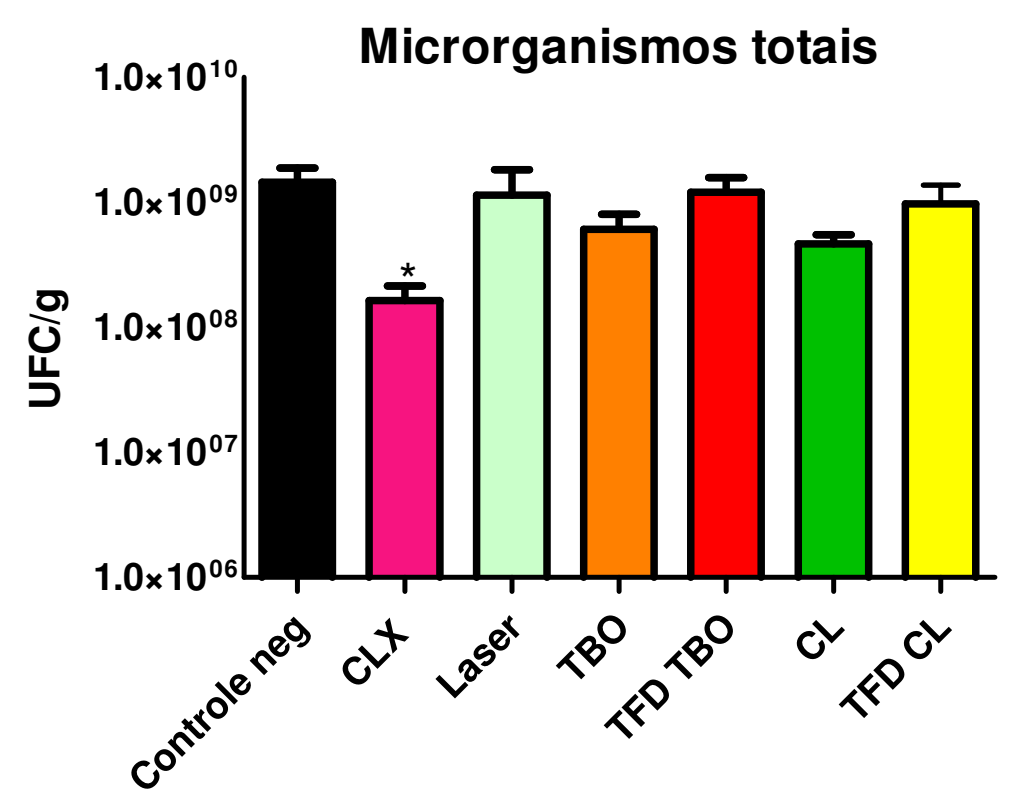

Gráfico 1: Contagem dos microrganismos totais (UFC por grama de biofilme) após plaqueamento e incubação por 48 horas.

\begin{tabular}{|l|l|}
\hline $\begin{array}{c}\text { Redução de microrganismos totais (\%) } \\
\text { em relação ao grupo controle }\end{array}$ \\
\hline Laser & $34 \pm 41$ \\
\hline CLX & $67 \pm 42$ \\
\hline CLX + Laser & $36 \pm 39$ \\
\hline TBO & $55 \pm 39$ \\
\hline TFD TBO & $45 \pm 38$ \\
\hline CL & $49 \pm 40$ \\
\hline TFD CL & $59 \pm 37$ \\
\hline
\end{tabular}

Tabela 2: Redução dos microrganismos totais (\%) em relação ao grupo controle negativo, após plaqueamento e incubação por 48horas. 


\section{Redução Microorganismos totais}

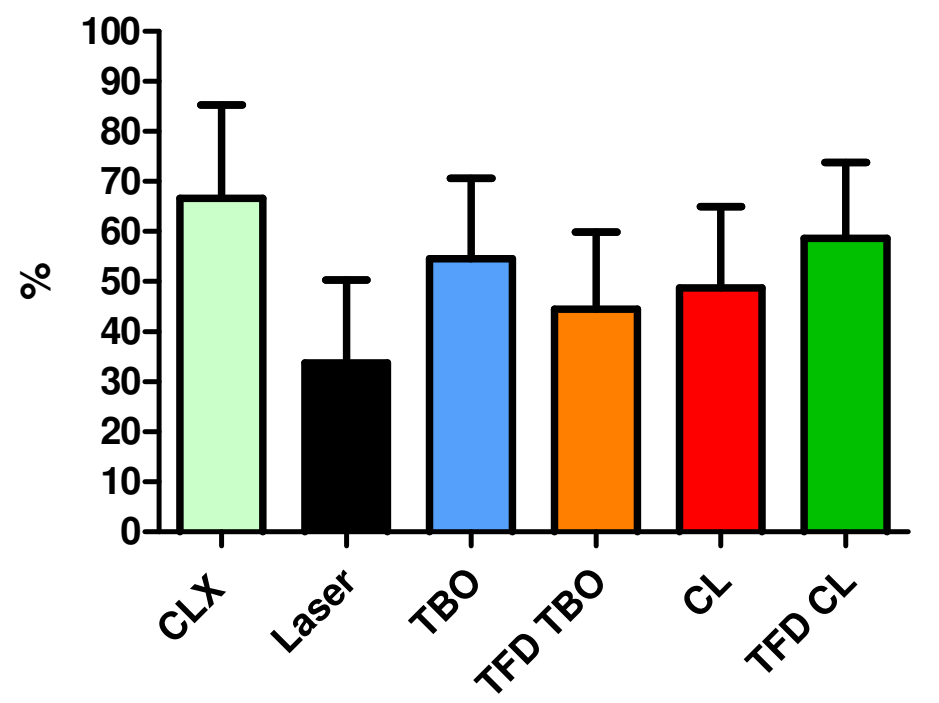

Gráfico 2: Redução dos microrganismos totais (\%) em relação ao grupo controle negativo, após plaqueamento e incubação por 48horas

\subsection{Contagem dos estreptococos totais}

O plaqueamento realizado nas placas de cultura contendo meio de cultura MS nos possibilitou analisar a quantidade de estreptococos totais recuperadas da placa bacteriana de cada grupo. Como já descrito, as UFC foram contadas após 48 horas de incubação em câmera de microaerofilia e foram calculadas em relação à quantidade de biofilme plaqueado. Foi possível realizar contagem nas diluições de $10^{3}$ e $10^{4}$. Diluições abaixo dessas mostraram crescimento exagerado, não sendo possível contagem e diluições de $10^{5}$ e $10^{6}$ não permitiram observar crescimento. Os resultados obtidos podem ser observados na Figura 7 e estão descritos na Tabela/Gráfico 3. São expressos em UFC/g.

Como nos resultados de plaqueamentos realizados em BHI, após análise estatística, adotando nível de significância de 0,05\%, o teste one-way ANOVA, para comparação entre os grupos não revelou diferença significante do número de microrganismos encontrado em cada grupo. $\mathrm{O}$ teste $\mathrm{t}$ de Student revelou diferença significante apenas entre o grupo controle negativo e o grupo tratado com clorexidina. No entanto, seguindo os resultados obtidos para os microrganismos 
totais, é possível perceber uma tendência de diminuição do número de bactérias viáveis em todos os grupos testes, ao se comparar com o grupo controle.

Para estes microrganismos, a clorexidina se mostrou ainda mais efetiva, alcançando quase $90 \%$ de redução.

Todos os grupos que receberam irradiação pela luz laser (somente luz, ou irradiação associada aos corantes (TBO e CL) foram os que apresentaram menor redução microbiana.

A redução observada para os grupos tratados com TBO ou CL sozinhos, foi semelhante. Porém, se mostrou maior que quando tais corantes foram associados a luz.

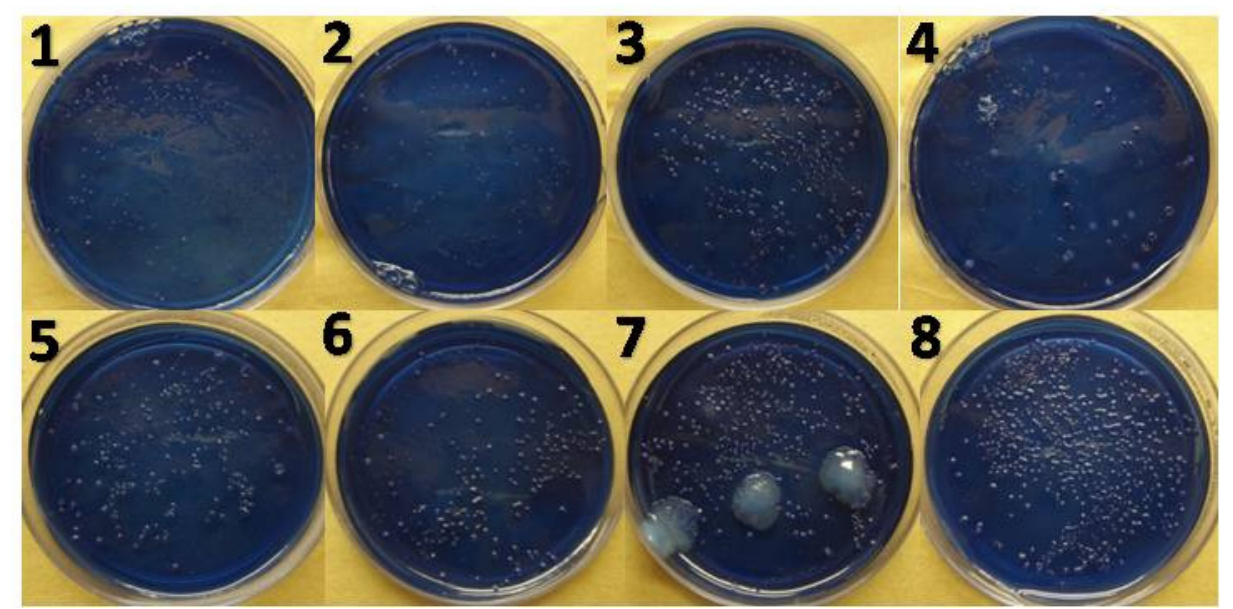

Figura 7: Plaqueamento de amostras dos oito grupos de um paciente em meio Agar MS, na diluição $10^{3}$, após $48 \mathrm{~h}$ em estufa a $37^{\circ} \mathrm{C}$.

\begin{tabular}{|l|l|l|l|l|}
\hline \multicolumn{5}{|c|}{ Estreptococos totais (UFC/g) } \\
\begin{tabular}{|l|l|l|l|l|}
\hline GRUPO & Controle & Laser & CLX & CLX + Laser \\
\hline & $1 \times 10^{9} \pm 2,1 \times 10^{9}$ & $7,9 \times 10^{8} \pm 9,7 \times 10^{8}$ & $7,2 \times 10^{\prime} \pm 6,1 \times 10^{7}$ & $2,4 \times 10^{8} \pm 4 \times 10^{8}$ \\
\hline GRUPO & TBO & TFD TBO & CL & TFD CL \\
\hline & $5,9 \times 10^{8} \pm 1,1 \times 10^{9}$ & $1 \times 10^{9} \pm 1,7 \times 10^{9}$ & $1,2 \times 10^{9} \pm 2,2 \times 10^{9}$ & $8,8 \times 10^{8} \pm 8,4 \times 10^{8}$ \\
\hline
\end{tabular}
\end{tabular}

Tabela 3: Contagem dos estreptococos totais (UFC por grama de biofilme) após plaqueamento e incubação por 48horas 


\section{Estreptococos totais}

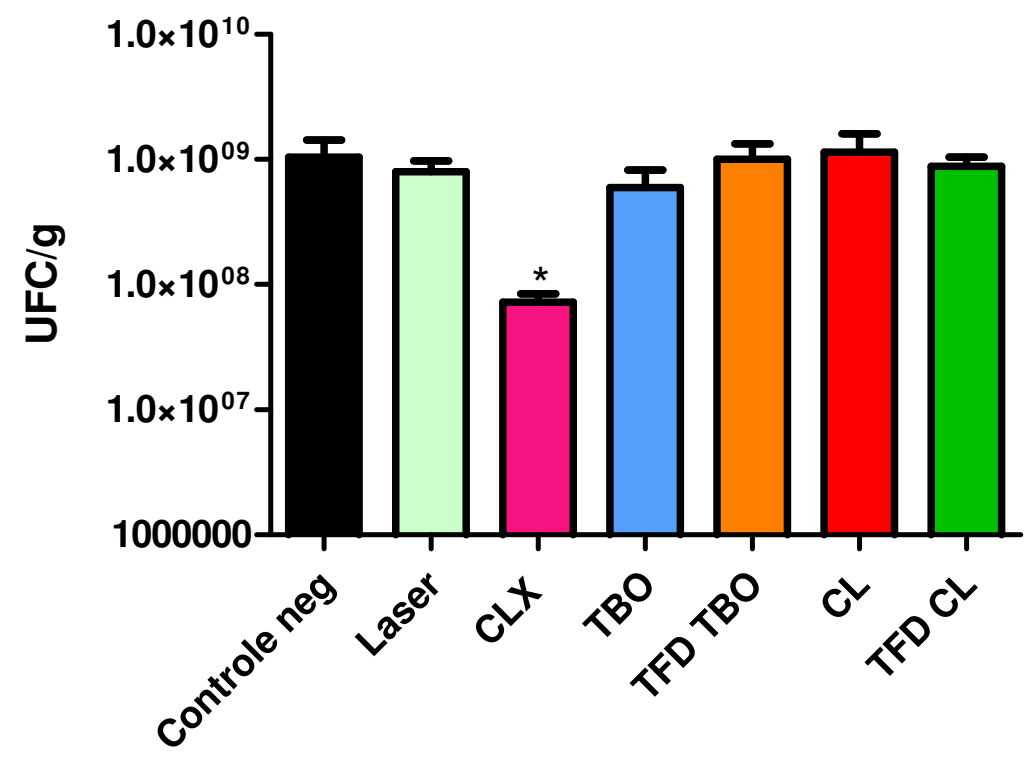

Gráfico 3: Contagem dos estreptococos totais (UFC por grama de biofilme) após plaqueamento e incubação por 48horas

\begin{tabular}{|l|l|}
\hline \multicolumn{1}{|c|}{$\begin{array}{c}\text { Redução de estreptococos totais (\%) } \\
\text { em relação ao grupo controle }\end{array}$} \\
\hline Laser & $37 \pm 35$ \\
\hline CLX & $89 \pm 12$ \\
\hline CLX + Laser & $54 \pm 42$ \\
\hline TBO & $51 \pm 35$ \\
\hline TFD TBO & $30 \pm 37$ \\
\hline CL & $51 \pm 38$ \\
\hline TFD CL & $30 \pm 35$ \\
\hline
\end{tabular}

Tabela 4: Redução dos estreptococos totais (\%) em relação ao grupo controle negativo, após plaqueamento e incubação por 48horas 


\section{Redução Estreptococos totais}

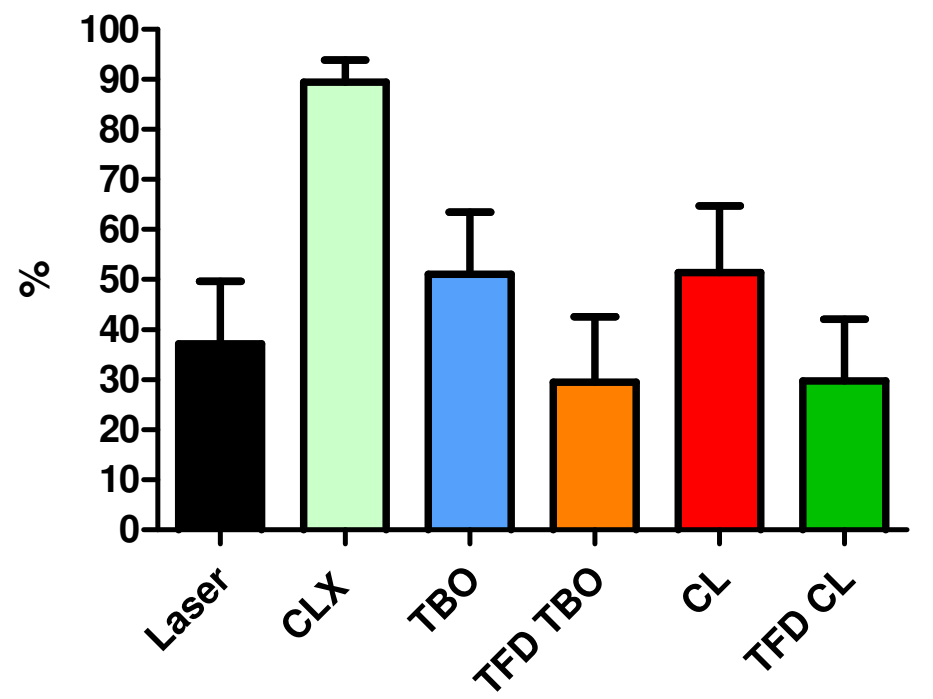

Gráfico 4: Redução dos microrganismos totais (\%) em relação ao grupo controle negativo, após plaqueamento e incubação por 48horas

\subsection{Contagem de S. mutans}

O plaqueamento realizado nas placas de cultura contendo meio de cultura SB20 associado à Bacitracina não nos possibilitou analisar a quantidade de $\mathrm{S}$. mutans recuperadas da placa bacteriana de cada grupo. As UFC eram analisadas após 48 horas de incubação em câmera de microaerofilia. Quanto se tentou a contagem, foi possível perceber uma grande quantidade de outros microrganismos também crescidos nessa placa, como leveduras ou $S$. sobrinus. Assim, não foi possível uma contagem exata e, portanto, não foi possível observar o real papel das terapias sobre tais microrganismos. 


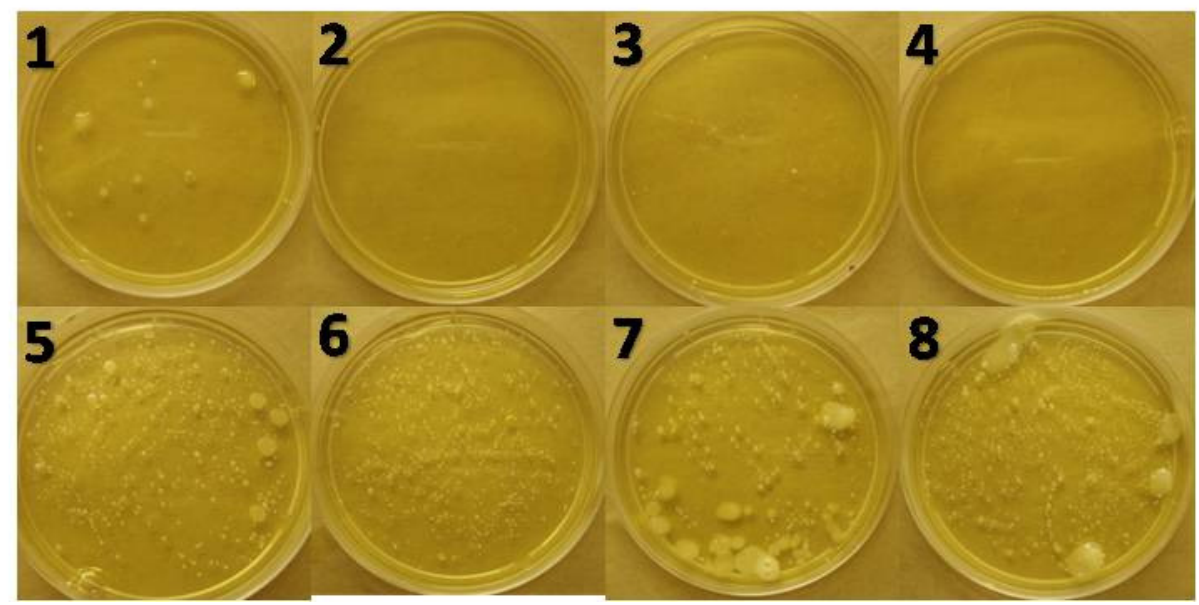

Figura 8: Plaqueamento de amostras dos oito grupo em meio SB20 acrescido de Bacitracina, na diluição $10^{1}$, após $72 \mathrm{~h}$ em câmara de microaerofilia e em estufa a $37^{\circ} \mathrm{C}$.

\subsection{Contagem de lactobacilos}

Após plaqueamento realizado nas placas de cultura contendo Agar Rogosa, específico para isolar lactobacilos, não foi possível perceber crescimento desse tipo de microrganismo na placa bacteriana de nenhum dos voluntários, em nenhum dos grupos. Na figura 6 podemos observar o aspecto das placas nos oito grupos de um voluntário, nas quais foram plaqueadas amostras não diluídas.

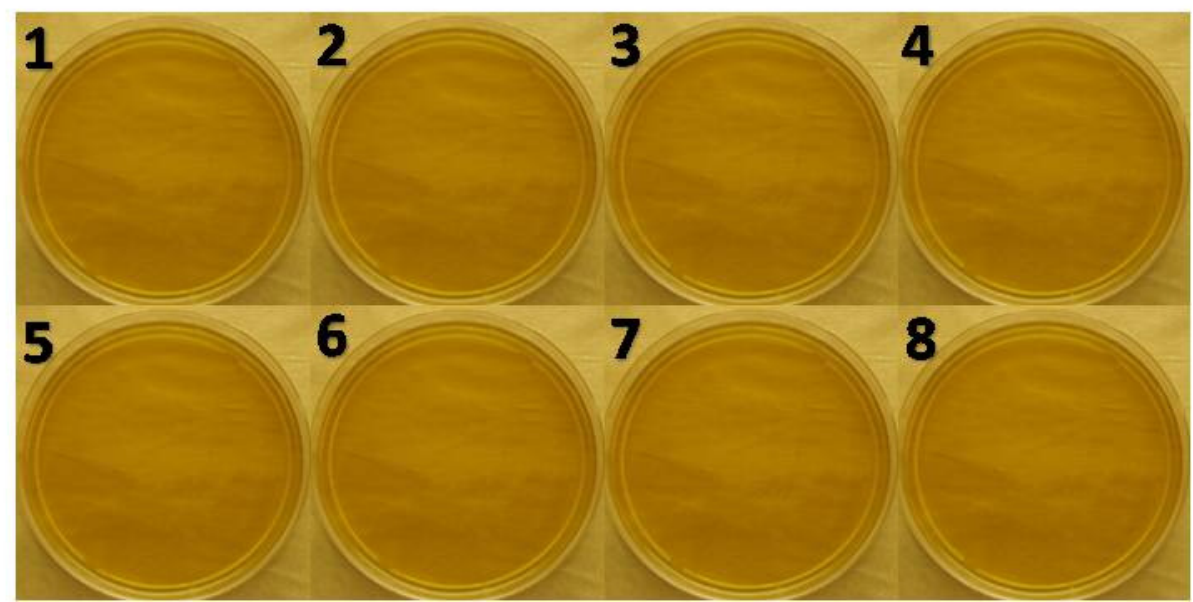

Figura 9: Plaqueamento de amostras dos oito grupo em meio Agar Rogosa, sem diluição, após $72 \mathrm{~h}$ em câmara de microaerofilia e em estufa a $37^{\circ} \mathrm{C}$. 


\subsection{Contagem de Candida}

Após plaqueamento realizado nas placas de cultura contendo Agar Sabauraud, específico para isolar Candida, foi possível perceber crescimento desse tipo de microrganismo na placa bacteriana de apenas um dos voluntários. No restante, não foi possível observar crescimento em nenhum dos grupos (controle ou tratamentos). Portanto, não se conseguiu analisar se as terapias seriam efetivas para tal microrganismo no biofilme.

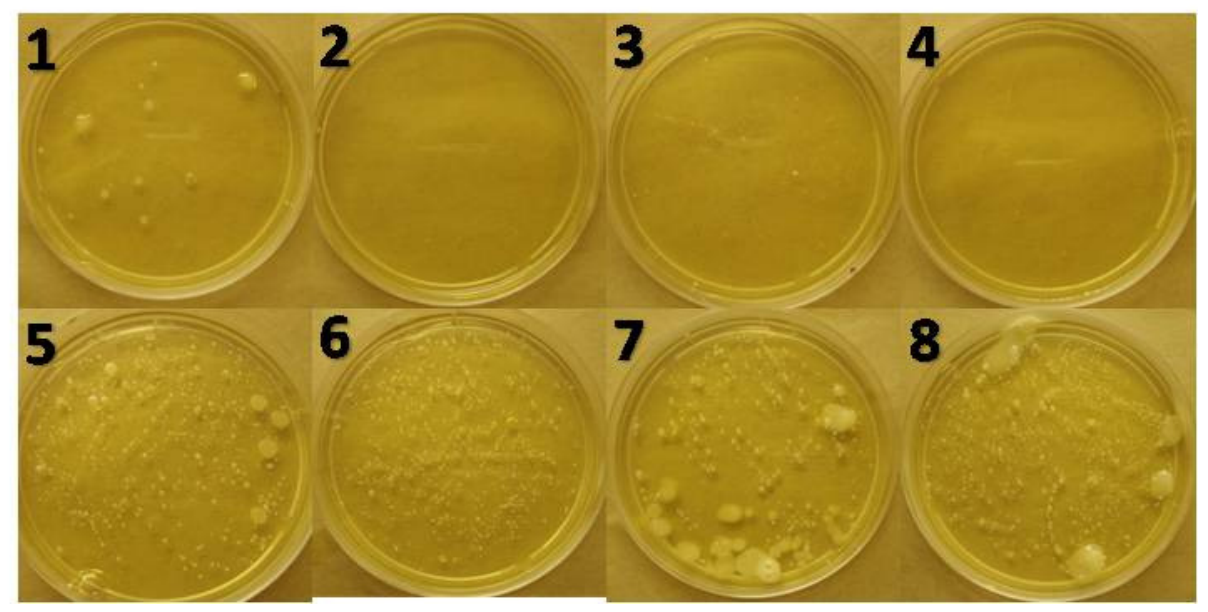

Figura 10: Plaqueamento de amostras dos oito grupos no paciente em que houve crescimento, em meio Agar Sabauraud, sem diluição, após $48 \mathrm{~h}$ em estufa a $37^{\circ} \mathrm{C}$

\subsection{Viabilidade dos microrganismos}

As células foram coradas com Laranja de Acridina para observação das células viáveis e não viáveis por microscopia de fluorescência. Imediatamente após a montagem das lâminas, estas eram observadas em um Microscópio Confocal (Leica TCS_nt) com magnificação de $63 x$ e zoom de $2 X$. Três campos aleatórios eram selecionados e aleatoriamente fotografados. As células marcadas em vermelho/ laranja eram aquelas que se mantinham viáveis. Ao contrário, células marcadas em verde, apresentavam-se inviáveis. Cada imagem foi analisada pelo programa BiolmageL, programa que quantifica a porcentagem de células marcadas em verde ou vermelho/laranja. A Tabela/Gráfico 5 mostram a porcentagem média \pm desvio padrão de células que se mostraram inviáveis para cada grupo. 


\begin{tabular}{|l|l|}
\hline \multicolumn{2}{|c|}{ Morte celular (\%) } \\
\hline Controle negativo & $59 \pm 35$ \\
\hline Laser & $56 \pm 29$ \\
\hline CLX & $58 \pm 38$ \\
\hline CLX + Laser & $66 \pm 29$ \\
\hline TBO & $56 \pm 30$ \\
\hline TFD TBO & $65 \pm 25$ \\
\hline CL & $70 \pm 19$ \\
\hline TFD CL & $63 \pm 28$ \\
\hline
\end{tabular}

Tabela 5: Média \pm desvio padrão da porcentagem de células consideradas inviáveis nas fotos obtidas por microscopia de fluorescência

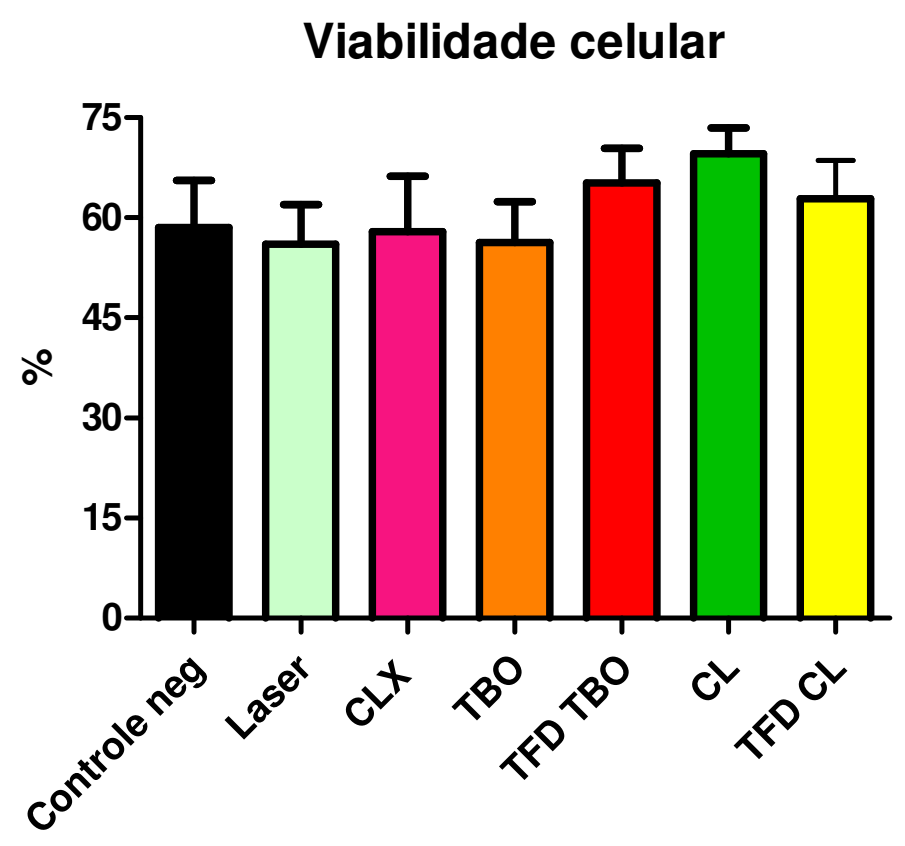

Gráfico 5: Porcentagem de células consideradas viáveis nas imagens obtidas por microscopia

Estes dados também foram analisados pelos testes estatísticos one-way ANOVA para comparação entre os grupos e teste t de Student, comparando o grupo controle com os outros grupos. Adotando nível e significância de 0,05\%, nenhum dos testes revelou diferença significante entre os grupos. 
Todos os grupos revelaram viabilidade celular semelhante, sendo sensivelmente maior nos grupos tratados com: TFDA com TBO, CL sem irradiação e TFDA com CL.

A figura 11 mostra as imagens obtidas dos 7 grupos de um dos pacientes.

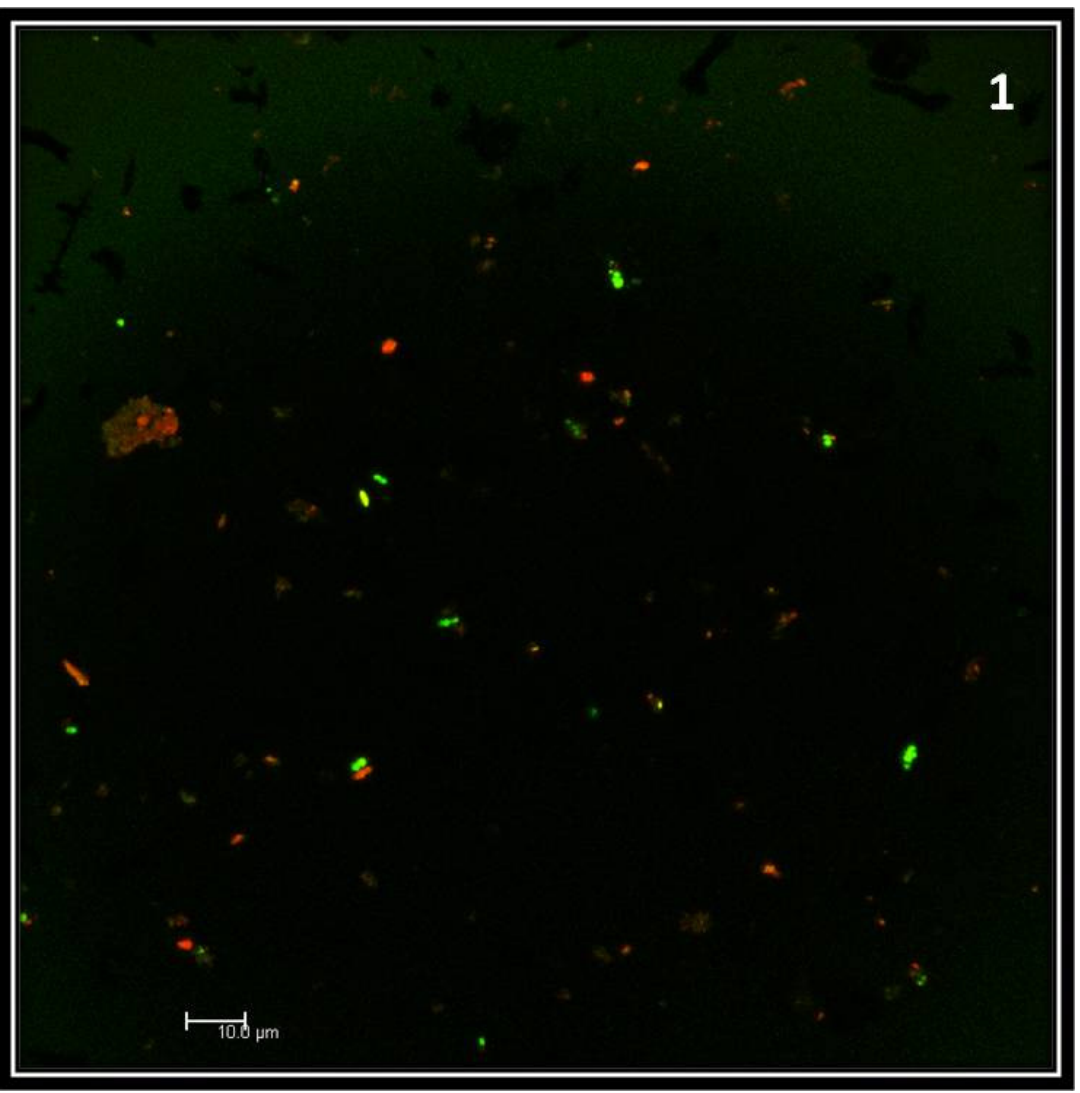



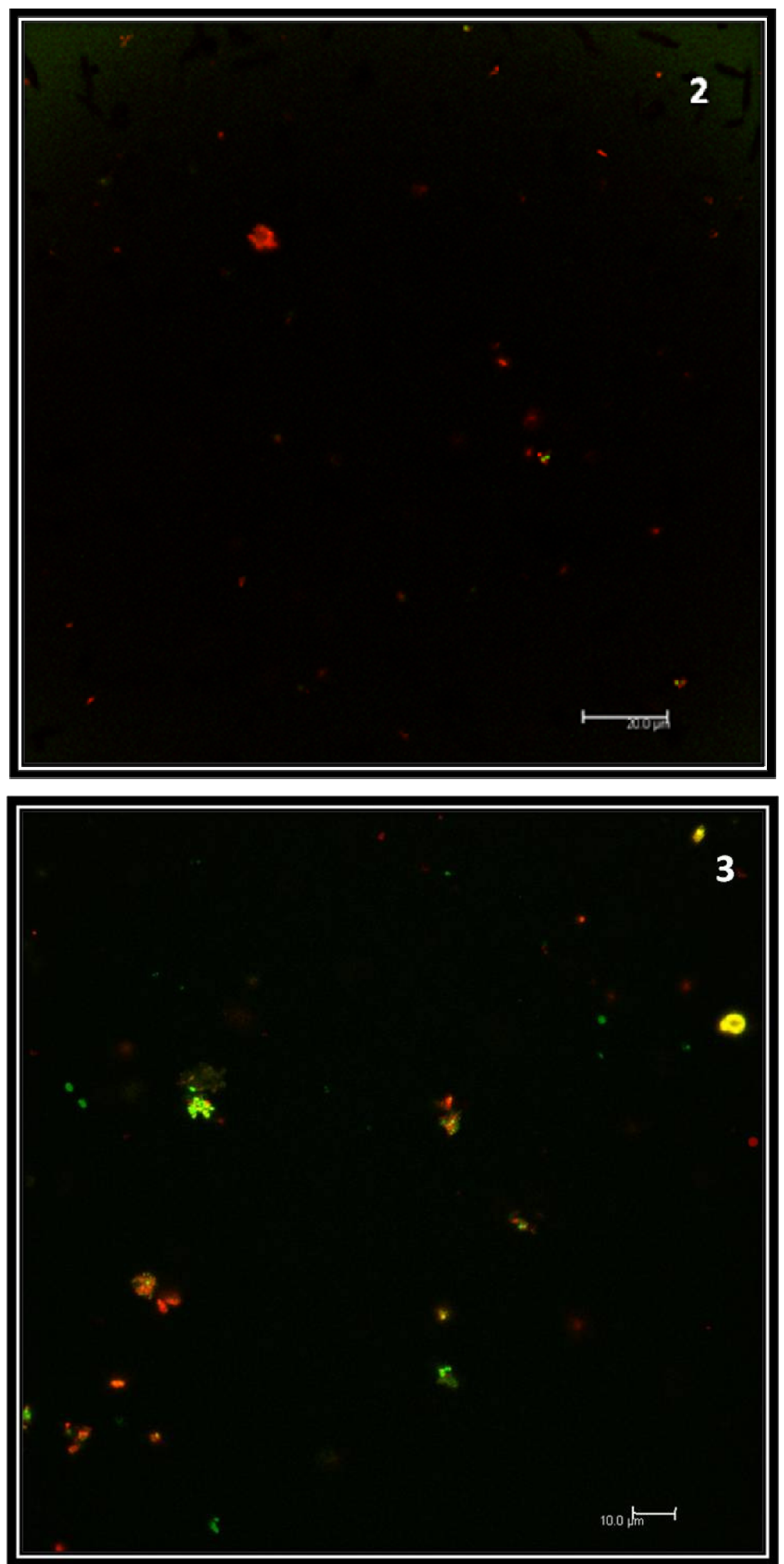

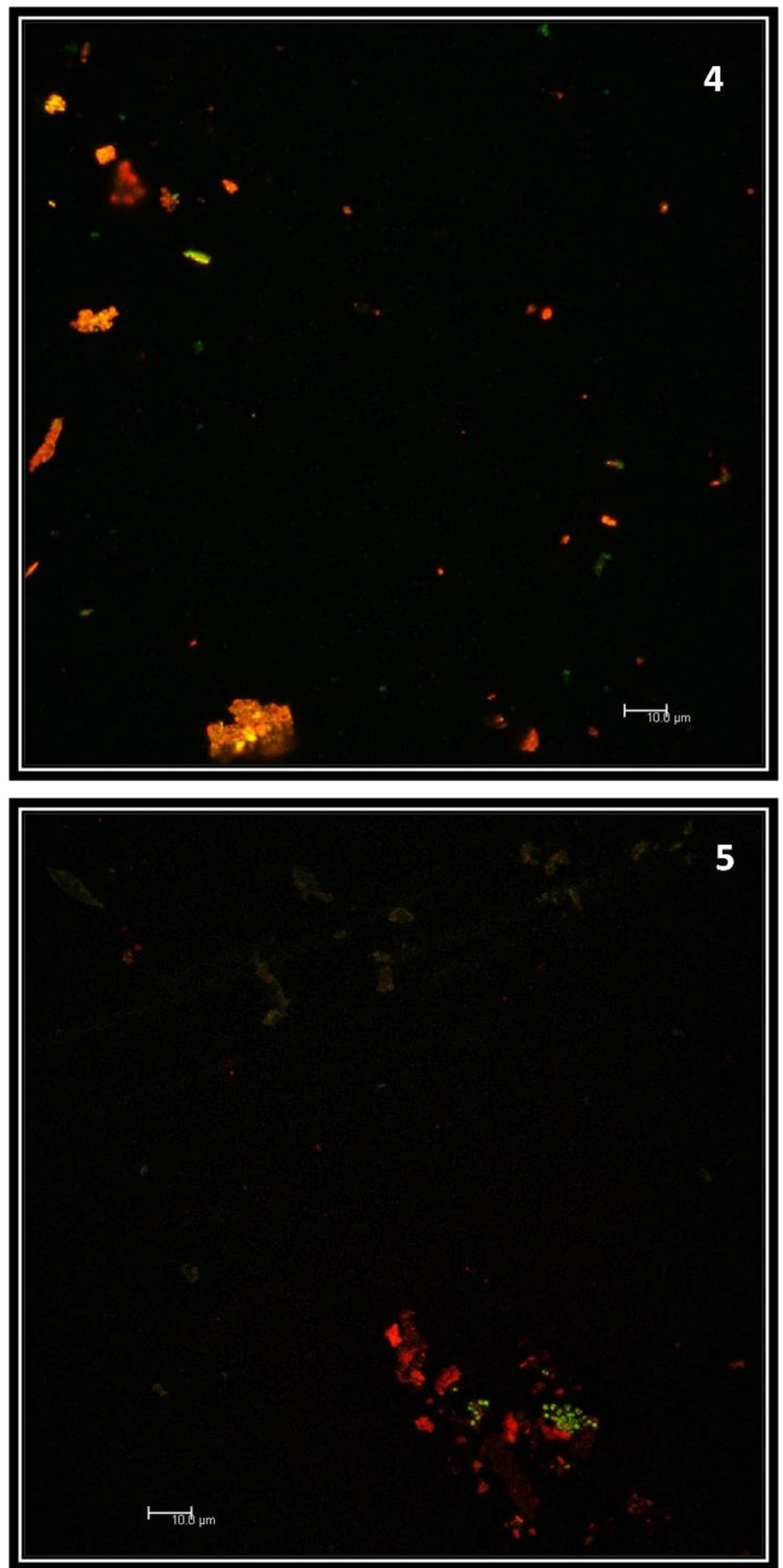

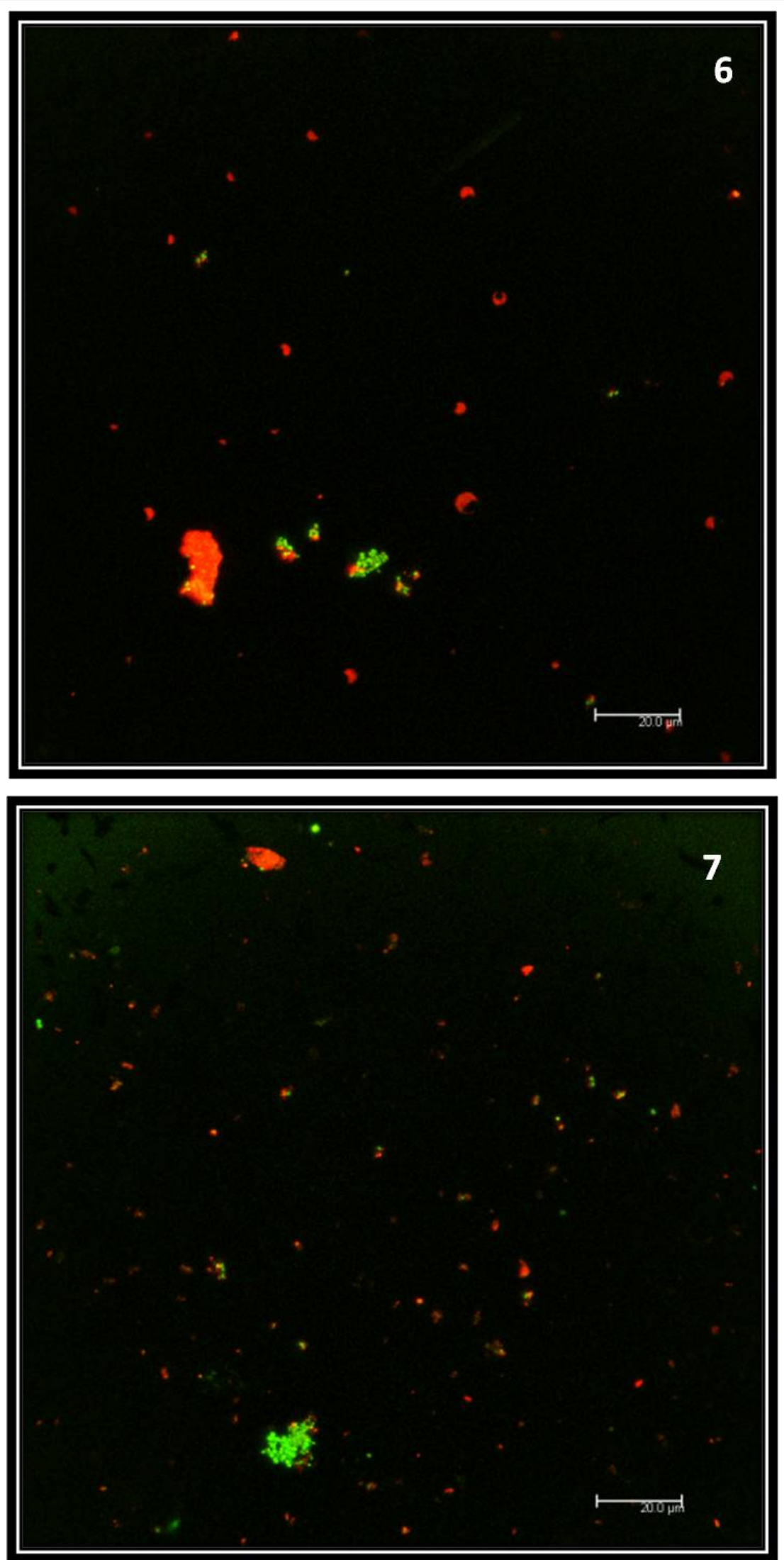

Figura 11: Imagens obtidas por microscopia de fluorescência após amostras serem coradas por laranja de acridina. Grupos 1 a 7 
Discussão 


$$
)
$$




\section{DISCUSSÃO}

Atualmente, é conhecido que a microbiota bucal é extremamente variada. Alguns microrganismos são comensais e apresentam caráter positivo, contribuindo para a saúde bucal de cada indivíduo. Outros, porém, são patogênicos. A colonização destes é dependente da interação entre eles e os comensais. Essa capacidade de se agregarem em complexos sobre as superfícies (conhecidos como biofilmes dentários, quando se formam sobre os dentes) as torna peculiares (WILSON, 2004; KOLENBRANDER et al., 2006).

Tem sido observado que bactérias inseridas nos biofilmes passam a exibir características fenotípicas distintas, o que também resulta no aumento de resistência dos biofilmes aos agentes antimicrobianos, ao stress do ambiente a aos mecanismos de defesa do hospedeiro. Além disso, nas últimas décadas, a resistência de bactérias, fungos, vírus aos antibióticos e terapêuticas comuns vem aumentando. Esses fatores levam a busca por métodos alternativos de morte desses patógenos e conseqüente tratamento das infecções (SOUKOS et al., 2003; DEMIDOVA et al., 2005; WINCKLER, 2006).

A TFDA pode ser uma alternativa potencial de tratamento, já que a erradicação das células alvo é conseguida através da ação de espécies citotóxicas, incluindo radicais livres e espécies reativas de oxigênio produzidas pela interação de um fotossensibilizador e irradiação de luz num comprimento de onda específico (para absorção máxima do fotossensibilizador). Assim, já que a atividade bactericida é devida a essas espécies reativas produzidas, a resistência torna-se improvável (ZANIN et al., 2005; GOIS et al., 2010).

Muitos estudos in vitro têm demonstrado a susceptibilidade de microrganismos encontrados na cavidade oral à TFDA (DE SIMONE et al., 1999; ROVALDI et al., 2000; CHAN et al., 2003; PAULINO et al., 2004; BLISS et al., 2004; MONFRECOLA et al., 2004; DEMIDOVA et al, 2005; PRATES et al., 2006; GEORGE e KISHEN, 2008; SOUZA et al., 2009; ARAUJO et al., 2009; MAISCH et al., 2009; BOLEAN et al., 2010).

Investigações têm sido feitas para analisar os efeitos da TFDA sobre biofilmes cariogênicos produzidos in vitro (DOBSON E WILSON, 1992; WILSON et al., 1995, 1996; O'NEIL et al., 2002; SEAL et al., 2002; SOUKOS et al., 2003, 2006; LEE et al., 2004; ZANIN et al., 2005; WOOD et al., 2006; WILLIANS et al., 2006; METCALF et 
al., 2006; WOOD et al., 2006; HOPE e WILSON, 2006; GARCEZ et al., 2007; GUGGENHEIM et al, 2007; SHARMA et al., 2007; DOVIGO et al., 2009; STREET et al., 2010; GOULAR et al., 2010; COLLINS et al., 2010) e os resultados também têm se mostrado favoráveis.

No entanto, poucos são os estudos investigando o papel da TFDA sobre o biofilme dentário humano formado in vivo (WOOD et al., 1999; SOUKOS et al., 2003; GARCEZ et al., 2008; LIMA et al., 2009; PINHEIRO et al. 2009), o que pode alterar as respostas devido às características peculiares encontradas no meio oral, tais como presença de saliva, suas proteínas, alterações de $\mathrm{pH}$, dentre outras.

.Assim, este estudo objetivou analisar os efeitos dessa terapia sobre um biofilme formado in vivo, sobre espécimes de esmalte bovino mantidos na cavidade oral de voluntários, após 48 horas na boca, e submetidos a 16 desafios cariogênicos. Estudos in situ levam a um maior entendimento dos processos metabólicos acontecidos no biofilme dentários, já que crescem diretamente na cavidade oral, e sua estrutura tridimensional não é manipulada (AUSCHILL et al., 2005).

Neste estudo, o biofilme foi formado sobre espécimes de esmalte bovinos. Dentes bovinos têm sido utilizados para estudos in situ devido a uma série de vantagens: sua obtenção e manipulação é mais simples na maioria dos locais e eles apresentam uma maior uniformidade na composição química, o que permite baixa variação nos resultados experimentais (CLASEN; OGAARD, 1999)

Os resultados obtidos com os parâmetros utilizados de TFDA não foram efetivos para o controle microbiano. Diversos fatores podem ter influenciado para se chegar a tais resultados, dentre eles podemos citar: as características peculiares de um biofilme formado na cavidade oral, microbiota presente nesse biofilme, a falta de penetração do corante e da luz em toda a profundidade do biofilme, dentre outros.

O grupo controle negativo serviu como parâmetro para a avaliação da presença e quantidade dos microrganismos estudados: bactérias totais, estreptococos, S. mutans, lactobacilos e $C$ albicans. O único tratamento que tal grupo recebeu foi água destilada $(25 \mu \mathrm{L})$, a fim de mimetizar uma possível lavagem que ocorreria com a aplicação do fotossensibilizador, que é liquido.

Analisando-se os microrganismos presentes nesse grupo, pode-se perceber claramente a presença de um grande número deles, pelo crescimento no meio $\mathrm{BHI}$. 
Também se observou grande número de bactérias do gênero dos estreptococos (crescidos em meio MS).

A colonização microbiana inicial que ocorre no primeiro dia após a formação da película adquirida, independente do tipo de superfície dentária, tem como principais colonizadores o $S$. sanguinis, $S$. oralis e $S$. mitis. (FREJERSKOV; KIDD, 2005; KOLENBRANDER et al., 2006). Juntas, essas três espécies de estreptococos representam $95 \%$ dos estreptococos e $56 \%$ da microbiota total inicial. Além disso, a microbiota inicial compreende Actinomyces sp. e bactérias Gram-negativas, como por exemplo Haemophilus sp. E Neisseria sp. Portanto, nossos resultados confirmaram a presença de grande número de estreptococos na composição de um biofilme dentário de 24 horas.

A detecção de $S$. mutans na cavidade oral de humanos está fortemente correlacionada com a prevalência de lesões de cárie (WEINBERGER; WRIGHT, 1989), com a predição de novas lesões (FUJIWARA et al., 1991) e com a determinação da atividade de cárie (KLOCK; KRASSE, 1979; KOHLER et al. 1981). Sua detecção no biofilme dentário humano e na saliva pode predizer o risco e servir para o monitoramento da atividade de cárie (FONTANA e ZERO, 2006), daí o interesse na sua quantificação no biofilme.

O meio SB20 acrescido de Bacitracina, que seria específico para se isolar esta espécie de microrganismo não cumpriu com esse objetivo, já que a identificação não foi possível neste estudo. Assim como em outros meios seletivos, nesse tipo de meio ocorre também o crescimento de outros cocos, mesmo que em menor escala. A dificuldade de visualização de $S$. mutans nesse meio, provavelmente ocorreu pela pequena quantidade desse microrganismo encontrada no biofilme dental precoce (até $48 \mathrm{~h}$ ), sendo possivelmente o crescimento de outras bactérias maior que o de $S$. mutans.

A identificação dessa espécie bacteriana é geralmente efetuada com base na morfologia das colônias (SVANBERG; KRASSE, 1990). O meio de cultura SB-20 foi proposto em 1984 por Davey e Rogers, tendo como base o meio de De Stoppellaar et al. (1967), e vem sendo empregado por vários pesquisadores (MOTSUKI et al., 2005; AYSEGULI et al., 2007). Sendo um meio de cultura seletivo e formulado com a adição de altas concentrações de bacitracina, permite o crescimento de $S$. mutans e $S$. sobrinus e inibe o crescimento de outros estreptococos da cavidade oral (HILDEBRANT; BRETZ, 2006). 
Durante muitos anos, acreditou-se que os $S$. mutans constituíam uma parte significante da microbiota oral inicial por causa da capacidade desses microrganismos de elaborar polissacarídeos extracelulares pegajosos, a partir da sacarose. No entanto, estudos têm mostrado que tais estreptococos compreendem apenas $2 \%$ ou menos da microbiota estreptocócica inicial, independentemente da exposição individual à sacarose. Os $S$. mutans são muito menos eficientes que os $S$. sanguinis em se aderir à superfície dentária. Cerca de $10^{4}-10^{5}$ células de $S$. mutans por mililitro de saliva devem estar presentes antes de uma célula ser recuperada de uma superfície dentária limpa, ao passo que a concentração equivalente para $S$. sanguinis é cerca de $10^{3}$ células/ml(FEJERKOV; KIDD, 2005; NYVAD; KILIAN., 1987; TAKAHASHI; NYVAD, 2010). Assim, como os voluntários participantes da pesquisa eram livres de cárie, mesmo que o biofilme dentário tenha sido produzido sob desafios cariogênicos (aplicação de sacarose 8 vezes ao dia sobre os espécimes dentais), em apenas 48 horas, provavelmente esse microrganismo não estava em quantidade suficiente no biofilme para visualização nesse tipo de meio de cultura. Daí, a dificuldade de diferenciação de tal espécie no meio SB20, mesmo que as amostras não tenham sido diluídas para plaqueamento.

A avaliação do potencial da TFDA contra $S$. mutans presente em biofilme dental humano precisa ser analisada em biofilmes acidogênicos, principalmente quando já haja desmineralização do dente, ou já esteja em estado de cavitação, como foi avaliado por Lima et al. (2009).

Quanto aos lactobacilos, não foi possível se isolar em nenhum dos pacientes em nenhum dos grupos. Fato também possivelmente explicado pelo fato dos voluntários não terem lesões de cárie dentária.

Lactobacilos são associados à progressão da cárie dentária (HAUKIOJA et al., 2008). Takahashi e Nyvad (2010) sugerem importante papel dos lactobacilos no processo da cárie dentária. Hemmens et al. (1946, apud BEIGHTON, 2005) demonstraram que lactobacilos colonizaram lesões de cárie, mas não são prevalentes na placa durante o período de formação da lesão. Van Houte et al. (1996) isolaram lactobacilos da placa encontrada em cavidades de cárie avançada em raiz, em diferentes pHs, mas este não foi isolado na superfície de raízes hígidas. A proporção de lactobacilos foi correlacionada com cárie. Takahashi e Nyvad (2010) ainda afirmam que enquanto o $S$. mutans está associado à lesão de cárie dentária 
inicial, os lactobacilos são oportunistas favorecidos pela mudança do meio ambiente provocada pela lesão inicial, já que lactobacilos são mais acidúricos.

O efeito da TFDA sobre espécies de Candida seria importante já que espécies desses microrganismos, que são patógenos oportunistas, fazem parte da microbiota comensal em $2-70 \%$ dos indivíduos saudáveis. No entanto é o responsável por causar infecções locais ou sistêmicas quando ultrapassam as barreiras imunes do indivíduo. Higiene oral deficiente tem sido relacionada com fator predisponente para aumento da quantidade de cândida e infecções por esta (ODDS, 1988). Por esses motivos, seria de grande interesse saber o papel da TFDA sobre essas espécies, quando presentes no biofilme.

Em nosso estudo, não foi possível alcançar tal objetivo, já que Candida não estava presente no biofilme dental formado em 48 horas sobre os espécimes da maioria dos pacientes. Darwaze et al. (2009) afirmaram que espécies de Candida estão presente na forma de biofilme, no entanto seu estudo não mostrou correlação entre o índice de placa e a colonização por Candida em indivíduos adultos saudáveis. Hipoteticamente, afirmaram que as células de Candida colonizam preferencialmente o biofilme dentário de pessoas com higiene bucal deficiente, que apresentam muita placa e inflamação gengival. Assim, como os voluntários deste estudo eram em sua maioria universitários, com amplas noções de higiene bucal e que provavelmente a realizam de maneira satisfatória, não permitiu o acúmulo deste microrganismo no biofilme formado, mesmo após desafios cariogênicos (sacarose 8 vezes ao dia).

Diante disso, nosso estudo conseguiu avaliar eficazmente o papel da TFDA contra os microrganismos totais e sobre estreptococos totais encontrados no biofilme dentário. Resultados como esses são importantes já que a formação do biofilme inicial é basicamente a coagregação e adesão entre espécies de Streptococcus spp e Actinomyces spp (ZJINGE et al., 2010).

Qualquer agente antimicrobiano visa à diminuição dos microrganismos. A clorexidina é a substância mais representativa dos agentes quimioprofiláticos e considerada efetiva contra o biofilme dentário e a gengivite. Diversos estudos mostram sua eficiência contra microrganismos encontrados na cavidade oral humana. $O$ efeito antiplaca da clorexidina é baseado no seu amplo espectro de ação contra as bactérias. Durante aplicação, ela atua de maneira bactericida e apresenta efeito bacteriostático posterior, mostrando sua substantividade. Normalmente novas 
terapias antimicrobianas são comparadas a ação de clorexidina (AUSCHILL et al., 2005; TOMÁS et al., 2008; Von OHLE et al., 2010). Portanto, ela foi utilizada como um controle positivo.

No presente estudo pudemos observar que a clorexidina 0,5\% (concentração mais alta que a considerada "Gold-Standard": 0,2\%, já que aplicaríamos uma única vez) embora não tenha erradicado os microrganismos encontrados no biofilme formado sobre os espécimes, diminuiu o número deles de maneira significante. Ao se analisar os microrganismos totais, a redução foi de $67 \pm 42 \%$. Auschill et al. (2005) demonstraram resultado similar em biofilme formado em 48 horas in situ e tratado com clorexidina $0,2 \%$, com redução de $89 \%$ da viabilidades das bactérias, comparando-se com um grupo controle tratado com água destilada. Esse resultado mais efetivo encontrado pelo autor, mesmo se utilizando clorexidina numa concentração mais baixa, provavelmente é devido a aplicação do antimicrobiano durante 4 vezes, no período estudado. Para estreptococos, notou-se uma redução um pouco maior: $89 \pm 12 \%$. Mc Bain (2003) mostrou que o grupo dos estreptococos é altamente sensível à clorexidina.

Em nosso estudo um fator que pode ter impedido uma redução maior (já que está não foi total) é a profundidade do biofilme. Estudos mostram que nem todas as bactérias de biofilmes conseguem ser alcançadas por substâncias antimicrobianas. Takenaka et al. (2008) descreveram que os danos celulares causados pela clorexidina sobre biofilmes orais sempre começavam pelas bactérias presentes na periferia e os efeitos iam diminuindo à medida que elas eram encontradas mais profundamente. A velocidade aparente de penetração da clorexidina nos biofilmes é de $4 \mu \mathrm{m} /$ minuto. Portanto, mesmo que a clorexidina atue rapidamente quando entra em contato com as células, talvez haja um tempo maior para sua ação nas células localizadas no interior. Em nosso estudo, o biofilme foi recolhido após 5 minutos do gotejamento de clorexidina, já que era um grupo controle positivo dos grupos em que a terapia fotodinâmica foi aplicada, e este era o tempo de pré-irradiação dos grupos da TFDA. Talvez, tempo insuficiente para que a substância chegasse até os microrganismos localizados mais profundamente no biofilme. Estudo de Pratten et al. (1998) mostrou que um biofilme formado por 5 das principais espécies bacterianas presentes no biofilme supragengival humano, in vitro, e exposto a clorexidina $0,2 \%$ não apresentou efeito inibitório após 5 minutos. Reduções consideráveis só foram visualizadas após 60 minutos de aplicação. Além disso, 
microrganismos diferentes são afetados de forma desigual. A eficácia da morte depende da idade do biofilme e de sua composição (Von OHLE et al., 2010).

Apesar dos microrganismos não terem sido erradicados, houve grande diminuição do número deles. A solução de clorexidina pode ser considerada um antimicrobiano efetivo, fato comprovado por este estudo, funcionando como controle positivo na comparação com as novas terapias testadas.

Ainda como grupo controle, um dos espécimes de cada paciente foi tratado apenas com a luz. A escolha da fonte de luz precisa conciliar a penetração da luz no tecido, o espectro de absorção do fotossensibilizador e a localização dos patógenos (MAISCH et al., 2007). As fontes de irradiação empregadas na TFD, em geral, são os laseres de baixa intensidade. A melhor fonte de irradiação tem sido descrita como aquela que apresenta custo acessível e forneça a maior quantidade de luz possível no máximo de absorção do fotossensibilizador, sem efeitos térmicos significativos. Os laseres, normalmente apresentam um elevado custo, no entanto, os laseres de diodo tem sido os mais usados, já que são portáteis, facilitando sua manipulação, apresentam custos mais acessíveis e cobrem praticamente todo o espectro visível e infravermelho próximo, podendo assim atender boa parte dos agentes fotossensibilizadores já existentes no mercado (MACHADO, 2000; KONOPKA et al., 2007).

Neste estudo, a fonte de luz utilizada foi o LASER HAND ${ }^{\circledR} / M M$ Optics Ltda. É um laser de diodo de baixa intensidade que irradia luz no intervalo espectral do visível $(660 \mathrm{~nm})$, sendo utilizado como coadjuvante em vários tratamentos terapêuticos em Odontologia, Medicina e Fisioterapia. Este aparelho emite luz apenas na faixa espectral prevista e potência calibrada, faixa esta que está no espectro de absorção dos corantes que foram utilizados. Ele apresenta potência de $40 \mathrm{~mW}$ e a dosagem de energia de aplicação escolhida foi de $30 \mathrm{~J} / \mathrm{cm}^{2}$. Em estudo piloto, não descrito aqui, realizado sobre biofilmes formados nas mesmas condições do estudo em questão, notou-se que doses acima dessa foram tóxicas para os microrganismos. Como a função objetivada para a irradiação com luz seria a fotoativação do fotossensibilizador, para que este executasse a função antimicrobiana, e não uma ação tóxica da luz, diminuiu-se a dose para $30 \mathrm{~J} / \mathrm{cm}^{2}$. Esta dose mostrou uma leve redução dos microrganismos totais em relação ao grupo controle negativo, cuja porcentagem atingiu somente o nível de $34 \%$ (a redução não foi estatisticamente significante e a porcentagem foi a menor dentre todos os grupos 
que receberam algum tratamento). Quanto aos estreptococos totais, o efeito foi parecido: leve redução, com porcentagem de redução de 37\%.

Esses dados estão em consonância aos encontrados por Rovaldi et al (2000). Tais autores utilizaram um laser de diodo de $662 \mathrm{~nm}$ e fluência de $15 \mathrm{~J} / \mathrm{cm}^{2}$ como fonte de luz na terapia fotodinâmica contra bactérias orais. Ao utilizar somente a irradiação, para análise do efeito dessa fonte de luz sobre os microrganismos, não foi possível perceber perda de viabilidade em comparação ao grupo controle.

Soukos et al. (2003) irradiaram biofilme removido de bolsas periodontais de pacientes com laser de diodo, na dosagem de $15 \mathrm{~J} / \mathrm{cm}^{2}$. Essa irradiação também não mostrou redução na viabilidade bacteriana.

Soukos et al. (2006) utilizaram como fonte de luz para terapia fotodinâmica, um laser de diodo de $1 \mathrm{~W}$, na dosagem de $30 \mathrm{~J} / \mathrm{cm}^{2}$, contra microrganismos causadores de infecções endodônticas ( $P$. micros; $E$. faecalis; $F$. nucleatin, $P$. intermédia, $P$. gingivalis, $P$. endodontalis). Tal dose da fonte de luz não mostrou redução da viabilidade de nenhum dos microrganismos.

Prates et al. (2006) utilizaram como fonte de luz na terapia fotodinâmica contra Aa um laser de diodo vermelho (660nm e $30 \mathrm{~mW})$ de Galio-Alumínio-Arsenio com doses de $5,4 \mathrm{~J} / \mathrm{cm}^{2}$ e $9 \mathrm{~J} / \mathrm{cm}^{2}$. A irradiação com ausência do fotossensibilizador não mostrou diferença na viabilidade bacteriana. No entanto, associado ao Verde de Malaquita, teve efeito dose dependente da luz.

Um laser de diodo de $664 \mathrm{~nm}$ com potência de $30 \mathrm{~mW}$ foi utilizado na terapia fotodinâmica contra Enterococcus faecalis na forma planctônica. O controle realizado somente pela irradiação não mostrou diferença na viabilidade bacteriana, comparado ao grupo controle (GEORGE; KISHEN, 2008).

Gois et al. (2009) avaliaram o papel da TFDA contra Staphylococcus aureus utilizando duas fontes de luz: um LED e um Laser de Diodo $\left(50 \mathrm{~mW} / \mathrm{cm}^{2}\right.$ e emitindo a $630 \mathrm{~nm}$ ). Ao utilizar somente a irradiação como tratamento (sem sensibilização prévia pela fotossensibilizador), também não houve diferença na viabilidade bacteriana quando comparado ao grupo controle.

Gasparetto et al. (2010) utilizaram como fonte de luz na terapia fotodinâmica contra Candida dublinienses, um laser de diodo de $685 \mathrm{~nm}$ de comprimento de onda, $35 \mathrm{~mW}$ de potência e com dose de energia $28 \mathrm{~J} / \mathrm{cm}^{2}$. A irradiação pela luz, sem a prévia sensibilização pelo fotossensibilizador (extrato de Alternanthera marítima) não mostrou redução no número de fungos de forma significante. 
Apesar da diversidade de dosimetrias utilizadas nos estudos, diante de todos os resultados apresentados e aqueles encontrados neste estudo foi possível perceber que o laser de diodo utilizado como tratamento único, contra diversos microrganismos encontrados na cavidade bucal, não apresentou efeito na redução da viabilidade destes, quando apresentados na forma planctônica ou organizados como biofilme. Portanto, nas doses analisadas não se apresentaria como tóxico contra as bactérias.

Diante de um tratamento antimicrobiano que utiliza um corante associado a uma fonte de luz para ativação desse corante, é necessário analisar o efeito tóxico desse corante utilizado isoladamente, a fim de ser saber que uma possível redução na viabilidade bacteriana advém do corante por si só, ou de sua ação após ser ativado pela fonte de luz (objetivo de uma terapia fotodinâmica). Portanto, neste estudo, a ação do corante isolada foi avaliada constituindo-se de um dos tipos de terapia aplicada sobre o biofilme formado sobre o espécime dentário.

Para cada voluntário, um dos espécimes presentes no dispositivo palatino teve como tratamento unicamente a aplicação do corante TBO. Um outro grupo constituiu-se da TFD propriamente dita: aplicação de TBO, seguida de um tempo de pré-irradiação de 5 minutos e irradiação.

O TBO é um composto fenotiazínico de cor azul com absorção máxima na região do vermelho visível (630nm) (comprimento próximo ao irradiado pelo laser usado neste estudo). É formado por uma estrutura tricíclica simples, sendo que seu tamanho e forma simples, o torna ideal para intercalação com ácidos nucléicos. Esse composto é normalmente comercializado na forma de sais com o cromóforo do corante sendo catiônico. Em solução, o corante é hidrofílico, porém em sistemas biológicos, O TBO é parcialmente convertido a sua forma neutra devido à desprotonação. Ele apresenta a propriedade de alterar a membrana citoplasmática bacteriana ligando-se aos polifosfatos presentes na camada externa desta membrana e possui potencial altamente hidrofóbico, o que facilita ainda mais sua ligação à camada lipídica. Esta propriedade aliada ao seu coeficiente de permeabilidade devido ao seu potencial catiônico faz com que ele se torne altamente concentrado no interior da bactéria aumentando seu poder destrutivo (USACHEVA; TEICHERT; BIEL, 2001). Esse corante, então, poderia ser efetivo na fotoinativação de microrganismos da cavidade oral. 
Após aplicação de $25 \mu \mathrm{L}$ de TBO sobre o biofilme formado sobre o espécime dentário, a quantidade de UFC crescida sobre as placas contendo meio de cultura $\mathrm{BHI}$ foi uma média de $5,9 \times 10^{8}$ por grama de biofilme plaqueado em comparação a média de $1,5 \times 10^{9}$ por grama de biofilme do grupo controle, o que resultou numa redução de aproximadamente $55 \%$. Portanto, o corante por si só já tem certo potencial tóxico sobre as bactérias totais, embora tal porcentagem não alcance os níveis alcançados pela clorexidina, nosso controle positivo.

Para analisar se os efeitos antimicrobianos do TBO aumentariam pela ativação por luz, em um dos grupos, a terapia fotodinâmica foi realizada: aplicou-se $25 \mu \mathrm{L}$ de TBO sobre o biofilme, esperou-se 5 minutos como tempo de pré-irradiação e irradiou-se a luz com dose de energia de $30 \mathrm{~J} / \mathrm{cm}^{2}$. Nesse grupo houve uma média de redução dos microrganismos totais de $45 \%$, portanto, menor que no grupo tratado somente com o corante. Essa redução não foi estatisticamente diferente do grupo controle ou do grupo tratado somente com TBO. Esse resultado demonstra que a terapia não foi efetiva contra os microrganismos totais formadores de biofilme humano.

Com os estreptococos, o efeito foi semelhante. A redução foi de aproximadamente $50 \%$ em relação ao grupo controle quando o biofilme foi tratado apenas com TBO. Essa redução caiu para 30\%, após irradiação pela luz.

Muitos estudos têm mostrado que TBO é efetivo como fotossensibilizador na terapia fotodinâmica contra bactérias em suspensão (DE SIMONE et al., 1999; WONG et al., 2005; SOUZA et al., 2009; ARAÜJO et al., 2009). Alguns estudos também têm demonstrado efetividade contra biofilmes, necessitando, no entanto, doses maiores de luz e concentrações maiores do corante (ZANIN et al., 2005, 2006; SHARMA et al., 2008) .

Williams et al. (2003), notaram morte de $100 \%$ de S. mutans na forma planctônica utilizando um laser de diodo e TBO como fotossensibilizador na concentração de $10 \mu \mathrm{g} / \mathrm{mL}$. Usacheva et al. (2001) avaliaram os efeitos da TFD contra bactérias gram-positivas e gram-negativas em suspensão, utilizando TBO como fotossensibilizador e um laser de argônio como fonte de luz. A terapia foi efetiva e os resultados foram dependentes da concentração do corante e da dose de irradiação da luz. O corante teve certa toxicidade mesmo sem a irradiação.

Souza et al. (2009) avaliaram os efeitos da terapia fotodinâmica em suspensões de $C$. albicans, utilizando vários fotossensibilizadores, dentre eles 0 
TBO na concentração de $0,1 \mathrm{mg} / \mathrm{mL}$. O resultado dependeu da dose utilizada da irradiação por laser de GaAlAs $\left(15,8 \mathrm{~J} / \mathrm{cm}^{2}, 26,3 \mathrm{~J} / \mathrm{cm}^{2}\right.$ ou $\left.39,5 \mathrm{~J} / \mathrm{cm}^{2}\right)$, sendo mais efetiva quanto maior a dose da luz. A aplicação de TBO isolada não mostrou diferença significante comparado ao grupo controle. Assim, TBO nessa concentração não apresentou efeitos citotóxicos em C. albicans.

Nos estudos citados acima, o fato dos microrganismos estarem sobre a forma planctônica pode ter influenciado nos resultados, já que nessa forma, os microrganismos são mais sensíveis a qualquer terapia antimicrobiana. Assim, o tratamento com TBO foi efetivo, mesmo com doses de TBO relativamente baixas (com exceção do tratamento de fungos). $O$ corante isoladamente apresentou certa toxicidade na maioria dos estudos, embora menor que a encontrada após sua fotossensibilização.

O Neil et al. (2002) investigaram o papel do TBO associado a luz de um laser de Hélio-Neônio em biofilme formado por múltiplas espécies presentes na cavidade bucal $(32,8 \%$ de Streptococcus spp, $6.5 \%$ de Veillonella spp., $0.1 \%$ Actinomyces spp., e $0.1 \%$ de anaeróbias Gram-negativas). Encontrou-se como resultado que a fotosensibilização do biofilme utilizando TBO na concentração de $25 \mu \mathrm{g} / \mathrm{ml}$ e dose de luz de $81,9 \mathrm{~J} / \mathrm{cm}^{2}$ resultou em morte de $97,4 \%$ das bactérias. A irradiação sozinha levou a morte de aproximadamente $26,9 \%$, semelhante ao observado em nosso estudo com o laser de diodo. No entanto, eles não observaram morte quando o TBO foi utilizado isoladamente, efeito diferente ao encontrado em nosso estudo, no entanto, o fotossensibilizador foi utilizado em concentração mais baixa.

Seal et al. (2002) compararam a morte bacteriana de biofilme de Streptococcus intermedius formado em canais radiculares usando irrigação de hipoclorito de sódio a $3 \%$ e terapia fotodinâmica com TBO como fotossensibilizador e laser de $\mathrm{He}-\mathrm{Ne}$ como fonte de luz. A combinação de $100 \mu \mathrm{g} / \mathrm{mL}$ de TBO e irradiação com $21 \mathrm{~J}$ de energia levaram à máxima redução das bactérias. $O$ uso do TBO em baixas concentrações (menores de $50 \mu \mathrm{g} / \mathrm{mL}$ ) não apresentou efeito bactericida, mas o TBO com a concentração de $100 \mu \mathrm{g} / \mathrm{mL}$ reduziu o número de bactérias viáveis, embora com porcentagem menor que a TFDA. A irradiação isolada teve efeito limitado. O hipoclorito erradicou as bactérias.

Williams et al. (2004) estudaram a susceptibilidade de $S$. mutans quando os organismos estão presentes em uma matriz de colágeno, ambiente similar ao que existe quando causam cárie dentária. Também foi analisada em bactérias presentes 
em dentes cariados. TBO foi utilizado como fotossensibilizador na concentração de $10 \mu \mathrm{g} / \mathrm{ml}$. A irradiação foi feita com luz laser em diversas doses de energia. Os efeitos antibacterianos obtidos foram menores do que os encontrados em suspensões bacterianas. No entanto, os resultados ainda mostraram que a terapia é hábil na morte de bactérias orais, incluindo $S$. mutans, quando estes microrganismos estão embebidos em colágeno ou presentes em dentes cariados. Quando TBO foi utilizado isoladamente, o efeito antibacteriano foi muito leve e sem diferença significante comparado ao seu controle.

Zanin et al. (2005) investigaram o efeito antimicrobiano do TBO combinado à irradiação por laser de $\mathrm{HeNe}$ ou LED na viabilidade e arquitetura de biofilme formado por S. mutans. O biofilme foi formado sobre discos de hidroxiapatita. Em seguida TBO na concentração de $1 \mathrm{mg} / \mathrm{ml}$ foi aplicado sobre os espécimes e, após serem mantidos 5 minutos no escuro, foram irradiados com diferentes densidades de energia: 49,147 e $294 \mathrm{~J} / \mathrm{cm}^{2}$. O efeito bactericida foi dependente da dose de luz aplicada e da idade do biofilme. No entanto, as reduções sempre foram maiores que $99 \%$.

Zanin et Al. (2006) estudaram o efeito da terapia fotodinâmica contra biofilme de $S$. mutans, $S$. sobrinus e $S$. sanguinis formado em 5 dias. $O$ fotossensibilizador utiizado foi TBO na concentração de $0,1 \mathrm{mg} / \mathrm{ml}$ associado a irradiação por um LED $\left(85,7 \mathrm{~J} / \mathrm{cm}^{2}\right)$. Houve redução significante (aproximadamente $95 \%$ ) da viabilidade de S. mutans e $S$. sobrinus e quase erradicação de $S$. sanguinis $(99,9 \%)$

Giusti et al. (2008) analisaram os efeitos da TFD em dentina bovina cariada, no qual a cárie foi desenvolvida in vitro pela incorporação dos espécimes em meio contendo S. mutans e Lactobacillus acidophilus. Utilizaram diferentes parâmetros para aplicação da terapia (concentração de TBO de 0.025 e $0.1 \mathrm{mg} / \mathrm{mL}$ e irradiação por LED com dose de energia de $24 \mathrm{~J} / \mathrm{cm}^{2}$ e $48 \mathrm{~J} / \mathrm{cm}^{2}$ ). Os melhores resultados foram obtidos com a concentração de TBO de $0,1 \mathrm{mg} / \mathrm{mL}$ e irradiação com $48 \mathrm{~J} / \mathrm{cm}^{2}$. Percebeu-se que TBO tem certa toxicidade, que aumentou de acordo com sua concentração. A irradiação de luz sem a presença do fotossensibilizador não apresentou efeito bactericida.

Sharma et al. (2008) invetigaram o efeito da ação fotodinâmica do TBO na viabilidade de biofilmes de Staphylococcus epidermidis e de cepas de Staphylococcus aureus resistentes à penicilina. Observou-se inativação das células quando o TBO foi associado à irradiação por um laser de diodo. Neste caso, o efeito 
foi dependente da dose de luz aplicada. A microscopia confocal a laser sugeriu danos na membrana das células bacterianas dos biofilmes tratados.

Assim, podemos perceber que a maioria dos estudos encontrou efeito da TFDA sobre biofilmes formados por bactérias orais quando o TBO foi associado à irradiação por uma fonte de luz. O corante isoladamente não foi tóxico, ou apresentou baixa toxicidade, mas a terapia apresentou-se efetiva. Assim, os dados encontrados diferem dos encontrados em nosso estudo. Isso pode ser explicado pela diferença de parâmetros utilizados e no tipo de biofilme estudado. A literatura existente sobre TFDA contra biofilme formado por bactérias orais tem aumentado nos últimos anos. No entanto, ainda não existem parâmetros definidos sobre qual fotossensibilizador utilizar, qual a concentração dessa substância, qual o tempo de pré-irradiação efetivo para cada tipo. O mesmo acontece com a fonte de luz, existindo diversos tipos de laser e LED, com diferentes comprimentos de onda, potência e doses de energia. Assim, a comparação entre os estudos torna-se uma tarefa complicada ou impossível.

O melhor efeito fotobactericida do TBO é relatado por sua afinidade ao LPS, presente nos microrganismos, ligando-se rapidamente a ele. Íons $\mathrm{Ca}^{+2}$ podem se ligar à superfície das bactérias (que são carregadas negativamente), principalmente ao LPS. Portanto, esse íon pode afetar a afinidade do TBO ao LPS, já que compete com ele na ligação (USACHEVA et al., 2006). Em nosso estudo, pelo biofilme ter sido formado in situ, saliva estava em contato o tempo todo com os espécimes de esmalte. Dentre os componentes salivares, o $\mathrm{Ca}^{+2}$ está presente na concentração de $2 \mathrm{mM}$, e pode ter tido influência na ação do TBO nas bactérias presentes no biofilme formado in situ. Usacheva et al., 2006, mostraram que $\mathrm{CaCl}_{2}$ inibiu a morte de $P$. aeruginosa, E. COli, S. marcescens, e K. pneumoniae, já que ligou-se ao LPS e outra proteínas da membrana celular.

Além disso, o fato de a irradiação diminuir a atividade antimicrobiana pode tentar ser explicado por uma reação de foto-branqueamento. Esse processo, que ocorre em substâncias cromóforas, corresponde a reações químicas induzidas pela luz, onde as moléculas são transformadas em outros compostos. O decréscimo da concentração do fotossensibilizador original no sítio de ação da TFDA e mesmo o menor poder de absorção de luz do cromóforo modificado, no comprimento de onda da fonte utilizada, acarreta em menor quantidade de princípios ativos excitados, situação que diminui a ação fotodinâmica. Em conseqüência tem-se menor formação 
de espécies citotóxicas, ou seja, ocorre um aspecto negativo na eficácia do tratamento. $\mathrm{O}$ oxigênio singlete, por ser uma espécie extremamente reativa, pode por si levar a degradação dos compostos fotossensibilizadores (os seus próprios precursores iniciais), caracterizando um tipo especial de foto-branqueamento. Em resumo, ao receber luz, o fármaco gera ${ }_{1} \mathrm{O}_{2}$, que por sua vez pode reagir com as próprias moléculas do substrato que o produziu, ocasionando nestas modificações químicas (SOARES, 2006). Portanto, é possível que TBO na concentração utilizado possa ter sofrido foto-branqueamento, o que prejudicou na sua ação antimicrobiana.

A utilização da $\mathrm{CL}$ como fotossensibilizador seguiu os mesmos parâmetros utilizados para TBO, devido à escassez de estudos que utilizam tal substancia na TFDA e a estudos pilotos realizados em nosso departamento. Assim, estudamos dois grupos para aplicação de CL. Um deles foi tratado somente com esse corante e o outro recebeu a terapia: $C L$ associado à irradiação por Laser.

A aplicação de produtos naturais de plantas tem uma longa tradição na medicina. Provavelmente a primeira aplicação prática da atividade fotodinâmica da clorofila foi o branqueamento de tecidos nas lavanderias. A clorofila, pigmento verde das plantas, contem clorina, uma porfirina, em seu esqueleto, que é a principal responsável pelas atividades fotodinâmicas (EBERMAN et al., 1996). Vários estudos têm mostrado papel de substâncias derivadas da clorofila (feofitina, feoforbide) na terapia fotodinâmica, principalmente no tratamento de câncer (LI et al., 2007; PARK et al., 1989; KELEHHER, 2003).

As clorofilas são moléculas formadas por complexos derivados da porfirina, tendo como átomo central o $\mathrm{Mg}$ (magnésio). Esse composto é uma estrutura macrocíclica assimétrica totalmente insaturada constituída por quatro anéis de pirrol. As plantas utilizam-se da radiação fotossinteticamente ativa (RFA ou PAR) que está compreendida entre 390 e 760nm (a chamada luz visível). Cada molécula de clorofila pode absorver apenas 1 quantum de energia de cada vez, o que causa excitação de um determinado elétron de um dos átomos da molécula. Os elétrons que estão em orbitais no estado estável do átomo recebem a energia e podem se deslocar para orbitais mais distantes do núcleo, a uma distância que é proporcional à energia de um fóton que absorveu. A molécula do pigmento encontra-se, então, no estado excitado, e é esta energia de excitação que é usada na fotossíntese. As clorofilas e outros pigmentos permanecem no estado excitado por períodos muito curtos (I bilionésimo de segundo $=10-9$ ) e a energia é perdida por calor ou por 
fluorescência) (STREIT et al., 2005). Segundo Soares (2006), a clorofila apresenta alta absorção na região de $665 \mathrm{~nm}$, próxima ao comprimento de onda irradiado pelo laser utilizado neste estudo.

As clorofilas são os pigmentos naturais mais abundantes presentes nas plantas e ocorrem nos cloroplastos das folhas e em outros tecidos vegetais (SOARES, 2006). Apesar dos poucos estudos de sua utilização como fotossensibilizador, ela foi escolhido neste tudo por ser a principal molécula responsável pela fotossíntese nas plantas, ou seja, por conseguir absorver a luz.

Para os microrganismos totais, embora o número de microrganismos contados nos grupos em que se utilizou somente o fotossensibilizador e naquele em que a $C L$ foi associada à irradiação tenha sido praticamente igual, a porcentagem de redução em relação ao grupo controle foi maior quando houve associação da luz (TFD $=59 \%$ e somente $\mathrm{CL}=49 \%$ ). No caso dos estreptococos, no entanto, o número de microrganismos contados nos dois grupos também foi semelhante. No entanto, a porcentagem de redução caiu de $51 \%$ (tratamento isolado com $\mathrm{CL}$ ) para $30 \%$ quando o fotossensibilizador foi associado à irradiação pelo Laser.

Torna-se importante frisar que o biofilme bacteriano é formado por microrganismos que produzem substâncias ácidas, o que leva a uma redução do pH local. Soares (2006) investigou o efeito do pH sobre a absorbância da clorofila (a $665 \mathrm{~nm})$. Observou-se que ao se trabalhar com soluções a pH 8,0 até ao redor de 5,3 , a clorofila a é estável. Nas soluções cujo pH se encontra entre 3,7 e 5,3 ocorre a reação de desmetalação (reação de troca com os prótons) sendo esta parcial ou completa, dependendo do teor de $\mathrm{H}^{+}$. Nesta região, o autor conseguiu monitorar a diminuição de absorbância com o tempo. Na faixa de pH entre 3,7 e 2,0 se verificou perda do metal por todas as moléculas de clorofila a, transformando-se em feofitina. Assim, em baixos níveis de pH, pela produção de ácidos pelas bactérias, é possível que a absorbância da clorofila tenha sido baixa, e portanto, houve deficiência em sua fotoativação.

Soares (2006) também estudou efeitos da iluminação de clorofila a sobre culturas de $S$ aureus, Escherichia coli e leveduras de Candida. Em nenhumas das concentrações utilizadas (até $300 \mu \mathrm{g} / \mathrm{mL}$ ) foi observado efetividade da terapia. Assim, os compostos não apresentaram bom desempenho frente às bactérias. Uma das explicações pode ser relacionada à baixa proximidade entre sítios biológicos alvos nos microrganismos e o local de geração das espécies oxidantes ativas, ou seja, do 
local em que se encontra o composto fotossensível. Sabe-se que o tempo de vida de espécies como o oxigênio singlete em tecidos biológicos é muito pequeno, inferior a $0,04 \mu \mathrm{s}$, o que restringe muito o raio de ação ao redor do seu foto-gerador (FOOTE et al., 1995).

Soares (2006) ainda observou que ocorre intensa reação de fotobranqueamento da clorofila a. Calculou-se cerca de $70 \%$ de perda do composto para um tempo total de 50 minutos de iluminação. Com sua diminuição de concentração e capacidade de absorção de luz (processo primário a TFDA) compromete-se a geração de oxigênio singlete ou de radicais livres. Assim, o fotobranqueamento sofrido pela clorofila a é uma das justificativas da ausência de atividade fotodinâmica observada nesta nos ensaios in vitro sobre os microrganismos investigados e sobre os ensaios in situ realizados por nós.

Portanto, esses dados talvez expliquem a ação mínima ou inexistente da CL como agente fotossensibilizador sobre biofilme dentário humano, em nosso estudo.

Biofilmes diferem de bactérias na forma planctônica em uma série de características: composição da parede celular, diferentes taxas de crescimento, taxa metabólica, expressão gênica, e presença de matriz extracelular, que pode atuar de forma protetora, servindo como protetora contra fatores adversos do ambiente, inclusive ação de agentes antimicrobianos. Por exemplo, pode impedir a absorção do fotossensibilizador e penetração da luz e, portanto, reduzir o processo de fotossensibilização. Assim, biofilmes são considerados menos susceptíveis a agentes antimicrobianos(ZANIN et al., 2005; O'NEILI et al., 2002; SHARMA et al., 2007).

Os resultados alcançados em nosso estudo mostraram ineficácia da terapia fotodinâmica sobre biofilme dentário humano, diferindo dos encontrados na maioria dos estudos que analisam o papel da terapia em biofilme. No entanto, na grande maioria estudou-se o papel antimicrobiano da terapia em biofilmes formados in vitro. Esses biofilmes, normalmente mimetizam as características da cavidade bucal, no entanto, somente o biofilme formado efetivamente na boca pode ser utilizado para avaliar os efeitos exatos do que aconteceria quando se aplica uma terapia em pacientes humanos. Suas características únicas de diversidade e interação bacteriana podem, por exemplo, dificultar a entrada de corantes nas bactérias ou a chegada de luz para ativação destas. 
O tempo de pré-irradiação utilizado (5 minutos) foi escolhido de acordo com outros estudos que utilizaram TBO como fotossensibilizador (Zanin et al., 2006; Junqueira et al., 2009). Além disso, cinco minutos é um tempo que poderia ser usado clinicamente. A grande maioria dos estudos faz uso, para bactérias, de tempos variando de 1 a 5 minutos, o qual tem sido suficiente para fotossensibilizar e inativar as espécies. Tem-se notado que o aumento do tempo de pré-irradiacao de 5 minutos para 1 ou 2 horas não tem nenhum efeito somatório na inativação dos microrganismos (WAINWRIGHT, 1998; JORI;BROWN, 2004).

No entanto, as características do biofilme in situ podem ser diferentes daquelas encontradas nos biofilmes formados in vitro, podendo levar a uma menor absorção do fotossensibilizador pelas bactérias presentes. $O$ que também seria um fator que não possibilitaria eficácia da TFDA.

Estudos que investigam os papeis da TFDA em biofilme formados in situ são raros (WOOD et al., 1999; LIMA et al., 2009). Wood et al. (1999) avaliaram o papel da TFD sobre biofilme humano produzido in situ, sobre espécimes dentários. Esse biofilme foi formado durante sete dias. Então os espécimes foram incubados com um fotossensibilizador catiônico: ftalocianina de zinco, e foram irradiados com luz branca. Os resultados demonstraram que o fotossensibilizador entrou no biofilme e que a terapia levou a morte dos microrganismos de maneira significativa. Adicionalmente, mostrou-se que os biofilmes tratados tinham menos espessura e estrutura diferente, com menos canais e menor densidade da biomassa, comparado ao grupo controle. A análise por microscopia elétrica de transmissão revelou danos nas bactérias, vacuolização do citoplasma e danos na membrana. Portanto, os resultados encontrados demonstraram potencial da TFDA para tratamento de biofilmes orais (Wood et al., 1999). O biofilme, apesar de formado in situ, como no nosso estudo, provavelmente apresenta-se diferente, por ser um biofilme mais maduro, o que o diferencia na sua estrutura, número e qualidade das bactérias. Além disso, os parâmetros utilizados diferem grandemente aos utilizados por nós quanto ao fotossensibilizador e a fonte de luz.

Lima et al. (2009) avaliaram o efeito da TFD sobre dentina cariada produzida in situ (em espécimes dentários tratados 10 vezes ao dia com solução de sacarose e mantidos durante 20 dias na boca dos voluntários). Analisou-se os efeitos antimicrobianos do TBO $(100 \mu \mathrm{g} / \mathrm{mLI})$ associado à irradiação de um LED $\left(47 \mathrm{~J} / \mathrm{cm}^{2}\right.$ ou $94 \mathrm{~J} / \mathrm{cm}^{2}$ ). Analisou-se os efeitos sobre microrganismos totais, estreptococos totais, 
S. mutans e lactobacilos. Observou-se redução significante na contagem bacteriana de todas as bactérias analisadas após a terapia com ambas as fontes de luz. No entanto, efeitos não foram mostrados quando TBO foi utilizado isoladamente, ou quando somente irradiou-se com $47 \mathrm{~J} / \mathrm{cm}^{2}$. A irradiação com $94 \mathrm{~J} / \mathrm{cm}^{2}$ também levou à redução significante (LIMA et al., 2009). Esse autor avaliou o papel da terapia sobre os mesmos microrganismos estudados por nós. Os resultados foram diferentes, já que mostrou efetividade da terapia. O TBO foi utilizado nas mesmas concentrações e seguindo o mesmo tempo de pré irradiação, mas a fonte de luz foi diferente. Além disso, a composição da placa também era diferente, sendo uma placa madura (20 dias).

Assim, além de haver poucos estudos in situ, a comparação fica complicada. O tempo de utilização do dispositivo intrabucal foi diferente. $E$ os parâmetros da TFDA também. A concentração, tempo de incubação, tipo de fotossensibilizador, assim como o estado fisiológico dos microrganismos, tempo de exposição e densidade da energia aplicada pelo laser podem influenciar de forma significante nos resultados (SOUZA et al., 1999).

Neste estudo, a viabilidade também foi analisada pelas imagens obtidas por microscopia de fluorescência, após as amostras terem sido coradas com laranja de acridina. Este corante é utilizado comumente como marcador de ácidos nucléicos em células vitais ou fixadas. Sendo um corante metacromático, ao tomar contato com as diferentes amostras microbianas, apresenta duas colorações. O corante se une ao RNA bacteriano emitindo fluorescência vermelha, e se une ao DNA bacteriano emitindo fluorescência verde. Diversos autores têm descrito que esta informação permite avaliar o metabolismo bacteriano, devido ao fato de que as células na fase logarítmica emitem fluorescência vermelha e aquelas na fase estacionária emitem fluorescência verde (RAPPOSCH; ZANGERL; GINZINGER, 2000; KEPNER; PRAT, 1994; URACHIMA; HOSHI; AKATSUKA, 1992; MCFETERS et al., 1991). Tem sido sugerido que a cor emitida pela bactéria pode, portanto, diferenciá-la como viável ou inviável. Se o microrganismo está viável e em crescimento, seu conteúdo de RNA é maior, emitindo coloração vermelha. No entanto, bactérias inativas contêm maior quantidade de DNA e emitem coloração verde.

Após dissolução do biofilme, parte das amostras foram coradas com laranja de acridina, lavadas e lâminas foram montadas para visualização em microscopia de 
fluorescência, a fim de se analisar a viabilidades dos microrganismos presentes em cada amostra. As lâminas foram observadas em microscópio confocal de varredura a laser imediatamente após a confecção. Escolheram-se três campos aleatórios, que foram fotografados e posteriormente analisados pelo software Bioimage_ $L^{\circledR}$. Como o biofilme apresentava-se diluído nas amostras, a escolha de 3 campos serviu como parâmetro do que estava acontecendo na amostra como um todo.

O software utilizado diferencia as células marcadas nas cores verdes das vermelhas/alaranjadas, caracterizando, portanto, a atividade metabólica e viabilidade dos microrganismos (CHÁVES DE PAZ, 2009). A microscopia associada às imagens digitais são amplamente utilizadas em pesquisas laboratoriais (GROSS; REDDY; DAZZO, 2010).

Após análise, não foi possível observar diferença significante entre nenhum dos grupos. Assim, tal resultado não foi compatível com a tendência encontrada pela contagem de UFC após plaqueamento do biofilme. A clorexidina, por exemplo, que se mostrou como efetiva diminuindo a contagem microbiana, não mostrou diferença na viabilidade, comparando-se ao grupo controle negativo. Embora com pouca diferença, os grupos tratados com CL ou com ambos os fotossensibilizadores associados à luz, mostraram-se com maior porcentagem de células viáveis, comparado ao grupo controle negativo. Tais resultados indicam que este não é um bom método de análise da viabilidade celular.

Um outro fator que deve ser levado em conta na interpretação dos resultados é que análise de biofilme solubilizado pode não representar os efeitos exatos da terapia. Pode-se pensar, por exemplo, que a terapia seja efetiva apenas nas camadas mais externas no biofilme, pelo fato da dificuldade de chegada do fotossensibilizador nas células localizadas mais profundamente, fato que não pode ser observado ao se analisar as células após solubilização. Além disso, as terapias podem atuar na matriz extracelular presente nos biofilmes. No entanto, em estudos realizados com biofilme formado in situ em disposivos intrapalatinos, esses dados são difíceis de ser analisados, já que não é possível a remoção dos espécimes dentários do dispositivo sem que se desorganizem os biofilmes. Como nosso principal objetivo seria a análise do papel das terapias sobre esse biofilme original, a aplicação da terapia foi feita no bloco ainda presente no aparelho, e depois se coletou o biofilme. Porém, a coleta já o desorganizou, sendo necessária a solubilização para análise do todo. 
Alguns autores demonstraram dificuldade na chegada do fotossensibilizador aos microrganismos presentes em biofilmes, mostrando que há aumento do poder antimicrobiano de algumas terapias (incluindo TFDA) quando está associada a substâncias quelantes, que ajudam na dispersão do biofilme e aumentam a permeabilidade das células. O sucesso da TFDA na inativação de biofilmes depende da penetração do fotossensibilizador e da luz nas camadas mais profundas (RAAD et al., 2007; SHARMA et al., 2007).

Mais estudos precisam ser realizados para analisar o real papel da TFD sobre o biofilme dentário humano. 
Conclusões 

6 CONCLUSÕES

Diante dos resultados obtidos podemos concluir que:

- A Clorexidina $0,5 \%$ tem ação antimicrobiana sobre os microrganismos presentes no biofilme dentário humano.

- A TFDA utilizando os corantes TBO e CL na concentração de $100 \mu \mathrm{g} / \mathrm{mL}$ associados à irradiação por laser de diodo na dose de $30 \mathrm{~J} / \mathrm{cm}^{2}$ não foi efetiva na redução microbiana do biofilme dentário humano.

- A Clorexidina é mais efetiva que a TFD com os parâmetros utilizados, na ação antimicrobiana sobre biofilme dental humano.

- Mais estudos da TFDA sobre biofilme dentário humano precisam ser realizados para avaliação de sua eficácia como agente antimicrobiano. 
$\underline{R e f e r e ̂ n c i a s ~}$ 


$$
\text { ) }
$$


REFERÊNCIAS

Allaker RP, The Use of Nanoparticles to Control Oral Biofilm Formation. J Dent Res. 2010 Aug

25. http://jdr.sagepub.com/content/early/2010/08/14/0022034510377794

Allison RR, Cuenca RE; Downie GH, Camnitz P, Brodish B, Sibata CH. Clinical photodynamic therapy of head and neck cancers-a review of applications and outcomes. Photodiagn Photodyn Ther 2005;2:205-222.

Allison RR, Bagntao VS, Cuenca R, Downie $\mathrm{GH}$, Sibata $\mathrm{CH}$. The future of photodynamic therapy in oncology. Future Oncol. 2:53-71. blue O. J Photochem Photobiol B. 2006; 86: 59-69.

Anderson M. Chlorhexidine and xilitol gum in caries prevention. Spec Care Dent. 2003;23(5):173-6.

Araújo PV, Teixeira KI, Lanza LD, Cortes ME, Poletto LT.In vitro lethal photosensitization of $\mathrm{S}$. mutans using methylene blue and toluidine blue $\mathrm{O}$ as photosensitizers. Acta Odontol Latinoam. 2009;22(2):93-7.

Attin R, Tuna A, Attin T, Brunner E, Noack MJ. Efficacy of differently concentrated chlorhexidine varnishes in decreasing Mutans streptococci and lactobacilli counts. Arch Oral Biol. 2003; 48(7):503-9.

Auschill TM, Hein N, Hellwig E, Follo M, Sculean A, Arweiler NB..Effect of two antimicrobial agents on early in situ biofilm formation.J Clin Periodontol. 2005;32(2):147-52.

Ayşegül O, Elgin IE, Gulcin A, Nedim S.The efficacy of chlorhexidine spray vs mouthwash in the microbial contamination of child toothbrushes. J Dent Child (Chic). 2007;74(3):177-81.

Bach G, Neckel C, Mall C, Krekeler G. Conventional versus laser-assisted therapy of periimplantitis: a five-year comparative study. Implant Dent 2000; 9:247-51.

Beighton D. The complex oral microflora of high-risk individuals and groups and its role in the caries process. Community Dent Oral Epidemiol. 2005 ;33(4):24855.

Ben-Hur E, MALIK Z, Dubbelman TMAR, Margakon P, Ali H, Van Lier JE. Phtalocyanine-induced photohemolysis: structure-activity relationship and the effect of fluoride. Photochem. Photobiol. 1993;58 (3):351- 55.

Bertolani g, Reddi E, Gatta M, Burlini C, Jori G. Factos influencing the haematoporphyrin-sensitized photoinactivation of Candida albicans. J Gen Mlcrobiol. 1989;135:957-66. 
Bevilacqua, I. M. The impact of photodynamic therapy on the viability of Streptococcus mutans in a planktonic culture. Photomedicine and Laser Surgery. 2007;25(6):513-18.

Biel MA, Photodynamic therapy in head and neck cancer. Curr Oncol Rep. 2002;4:87-96.

Bolean M, Paulino Tde P, Thedei G Jr, Ciancaglini P. Photodynamic therapy with rose bengal induces GroEL expression in Streptococcus mutans. Photomed Laser Surg. 2010;28(1):79-84.

Bonnett R. Photodynamic therapy in historical perspectiveRev. Contemp. Pharmacother. 1999.

Bozkurt FY, Ozturk M, Yetkin Z. The effects of three oral sprays on plaque and gingival inflammation. J Periodontol.2005;76(10):1654-60.

Castano AP, Demidova TN, Hamblin MR. Mechanisms in photodynamic therapy: part two-cellular signaling, cell metabolism and modes of cell death. Photodiagn Photodyn Ther. 2005; 2:1-23.

Chad E, Joseph M, Bliss B, Foster TH, Haidaris CG. Susceptibility of Candida Species to Photodynamic Effects of Photofrin antimicrobial agents and chemotherapy. 2004; 48(6): 2000-6.

Ccahuana-Vásquez RA, Cury JA. S. mutans biofilm model to evaluate antimicrobial substances and enamel demineralization. Braz Oral Res.2010;24(2):135-41.

Chabrier R.Y Thomas H.F; Nelissa Pe'rez-Nazario,1 Soumya Mitra,2 and Constantine G. Haidaris1. Sensitivity of Candida albicans Germ Tubes and Biofilms to Photofrin-Mediated Phototoxicity antimicrobial agents and chemotherapy. 2005; 49(10):4288-295.

Chabrier RF, Thomas H. Foster2, Soumya M, Constantine G. Haidaris Respiratory Deficiency Enhances the Sensitivity of the Pathogenic Fungus Candida to Photodynamic Treatment Photochemistry and Photobiology. 2008;84: 1141-148.

Chan $\mathrm{Y}$, Lai $\mathrm{CH}$ Bactericidal effects of different laser wavelengths on periodontopathic germs in photodynamic therapy. Lasers Med Sci 2003; 18:5155.

Chávez de Paz LE. Image Analysis Software Based on Color Segmentation for Characterization of Viability and Physiological Activity of Biofilms Appl Environ Microbiol. 2009 ;75(6):1734-39.

Chen H, Yu A, Han J, Mi Y. Anal. Lett. 1995:28:1579 
Clasen AB, Ogaard B. EExperimental intra-oral caries models in fluoride research. Acta odont scand. 1999; 57(6):334-41.

Collins TL, Markus EA, Hassett DJ, Robinson JB.The effect of a cationic porphyrin on Pseudomonas aeruginosa biofilms. Curr Microbiol. 2010;61(5):4116.

Darwazeh AM, Hammad MM, Al-Jamaei AA. The relationship between oral hygiene and oral colonization with Candida species in healthy adult subjects*. Int $\mathrm{J}$ Dent Hyg. 2010;8(2):128-33.

Demidova TN, Hamblin MR (2005). Effect of cell-photosensitizer binding and cell density on microbial photoinactivation. Antimicrob Agents Chemother. 2005; 49:2329-35.

Ezequiel D. Quiroga, María Gabriela Alvarez, Edgardo N. Durantini Susceptibility of Candida albicans to photodynamic action of 5,10,15,20-tetra(4-Nmethylpyridyl)porphyrin in different media FEMS Immunology \& Medical Microbiology. 2010; 60(2):123-31

Dovigo LN, Pavarina AC, de Oliveira Mima EG, Giampaolo ET, Vergani CE, Bagnato VS.Fungicidal effect of photodynamic therapy against fluconazoleresistant Candida albicans and Candida glabrata. Mycoses. 2009 .

Desimone, N.A., Christiansen, C, Dore, D. Bacterial effect of 0,95 mW heliumneon and $5 \mathrm{~mW}$ indium-gallium-aluminium-phosphate laser irradiation at exposure times of 30,60, and 120 seconds on photosensized Staphylococus aureus and Pseudomonas aeruginosa in vitro. Phys Ther. 1999.;79(11):.1082.

Dobson J, Wilson M. Sensitization of oral bacteria in biofilms to killing by light from a low-power laser. Arch Oral Biol. 1992; 37:883-887.

Dolphin, D.; The porphyrins. Physical Chemistry. Part C (vol. V). Academic Press Inc., New York, EUA, 1978.

Donelly RF, Mcarrin PA, Tunney MM, Woolfson AD. Potential of photodynamic therapy in treatment of fungal infections of the mouth. Design and characterisation of a mucoadhesive patch containing toluidine blue $\mathrm{O}$. $\mathrm{J}$ Photochem Photobiol B: Bio. 2007;86:59-69.

Donnelly RF, Paul A. McCarron A. David Woolfson. Drug Delivery of minolevulinic Acid from Topical Formulations Intended for Photodynamic Therapy Photochemistry and Photobiology. 2005;81(4):750-67

Dortbudak O, Haas R, Bernhart T, Mailath-Pokorny G. Lethal photosensitization for decontamination of implant surfaces in the treatment of peri-implantitis. Clin Oral Implants Res. 2001; 12:104-108. 
Dougherty TJ, Gomer CJ, Henderson BW, Joru G, Kessel D, Korbelik M. Photodynamic therapy. J Natl Cancer Inst. 1998; 90:889-905.

Ebermann, R, Alth,G, Kreitner,M . Kubin a products derived from plants as potential drugs for the photodynamic destruction of tumor cells. Journal of Phorochemistry and Pbmbiology 8: Biology 36 1996;95-97

Ernst CP, Canbek K, Dillenburger A, Willershausen B. Clinical study on the effectiveness and side effects of hexetidine and chlorhexidine mouthrinses versus a negative control. Quintessence Int. 2005;36(8):641-52.

Evans RC, Holmes CJ Effect of vancomycin hydrochloride on Staphilococcus epidermidis biofilm associated with silicone elastomer. Antimicrob Agents. 1987;31(6): 889-94.

Fejerskov O, Kidd E. Carie dentária: a doença e seu tratamento clínico. São Paulo, Ed. Santos. 2005;12:179-88.

Fimple, J.L., Fontana, CR , Foschi, F K. Ruggiero, X. Song, TC. Pagonis, AC Tanner, R. Kent, A. G. Doukas, P. P. Stashenko and N. S. Soukos. Photodynamic treatment of endodontic polymicrobial infection in vitro. J. Endod. 2008;34:728734.

Fontana M, Zero DT. Assessing patients' caries risk. J Am Dent Assoc.2006; 137(9):1231-9.

Foote RL, Loprinzi CL, Frank AR, O'Fallon JR, Gulavita S, Tewfik HH. Randomized trial of a chlorhexidine mouthwash for alleviation of radiation-induced mucositis. Journal of Clinical Oncology 1994;12:2630-3.

Freitas I, Baronzio GF. Tumor hypoxia, reoxygenation and oxygenation strategies: possible role in phodynamic therapy, $J$ Photochem. Photobiol.1991;11:3-30.

Fujiwara T, Sasada E, Mima N, Ooshima T. Caries prevalence and salivary mutans streptococci in 0-2-year-old children of Japan. Community Dent Oral Epidemiol. 1991;19(3):151-4.

Garcez AS, Ribeiro MS, Tegos GP, Núñez SC, Jorge AO, Hamblin MR. Antimicrobial photodynamic therapy combined with conventional endodontic treatment to eliminate root canal biofilm infection. Lasers Surg Med. 2007;39(1):59-66.

Garcez AS, Nuñez SC, Hamblin MR, Ribeiro MS. Antimicrobial effects of photodynamic therapy on patients with necrotic pulps and periapical lesion. $J$ Endod. 2008;34(2):138-42.

Gasparetto A, Lapinski TF, Zamuner SR, Khouri S, Alves LP, Munin E, Salvador MJ. Extracts from Alternanthera maritima as natural photosensitizers in 
photodynamic antimicrobial chemotherapy (PACT). J Photochem Photobiol B. 2010;99(1):15-20. Epub 2010 Jan 25.

George, S , Kishen, A. Influence of Photosensitizer Solvent on the Mechanisms of Photoactivated Killing of Enterococcus faecalis Photochemistry and Photobiology. 2008;84:734-40.

Giroldo LM, Felipe MP, de Oliveira MA, Munin E, Alves LP, Costa MS. Photodynamic antimicrobial chemotherapy (PACT) with methylene blue increases membrane permeability in Candida albicans Lasers Med Sci.2009;24:109-12

Giusti JS, Santos-Pinto L, Pizzolito AC, Helmerson K, Carvalho-Filho E, Kurachi $\mathrm{C}$, Bagnato VS.Antimicrobial photodynamic action on dentin using a light-emitting diode light source. Photomed Laser Surg. 2008;26(4):281-7.

Gois MM, Kurachi C, Santana EJ, Mima EG, Spolidório DM, Pelino JE, Salvador Bagnato V. Susceptibility of Staphylococcus aureus to porphyrin-mediated photodynamic antimicrobial chemotherapy: an in vitro study Lasers Med Sci. 2010;25(3):391-5.

Gomer CJ, Razum NJ. Acute skin response in almino mice following porphirin photosensitization under oxic and anoxic conditions. Photochem. Photobiol.1984;40:435-9.

Goulart Rde C, Thedei G Jr, Souza SL, Tedesco AC, Ciancaglini P. Comparative study of methylene blue and erythrosine dyes employed in photodynamic therapy for inactivation of planktonic and biofilm-cultivated Aggregatibacter actinomycetemcomitans. Photomed Laser Surg.2010;28(1)85-90.

Grant WE, Speight PM, Hopper C, Bown SG. Photodynamic therapy: an effective, but non-selective treatment for superficial cancers of the oral cavity. Int $\mathrm{J}$ Cancer.1997;71:937-942.

Grinholc M, Szramka R, Olender K , Graczyk A.Bactericidal effect of photodynamic therapy against methicillin-resistant Staphylococcus aureus strain with the use of various porphyrin Photosensitizers Acta Biochimica Polonica.2007:54(3): 665-70.

Gross CA, Reddy CK, Dazzo FB. CMEIAS color segmentation: an improved computing technology to process color images for quantitative microbial ecology studies at single-cell resolution. Microb Ecol. 2010;59(2):400-14. Epub 2009 Dec 19.

Grossman MC. What's new in cutaneous laser research? Dermatol.Clin.1997;15:1-8.

Haas R, Dortbudak O, Mensdorff-Pouilly N, Mailath G. Elimination of bacteria on different implant surfaces through photosensitization and soft laser. An in vitro study. Clin Oral Implants Res.1997; 8:249-54. 
Haas R, Baron M, Dortbudak O, Watzek G. Lethal photosensitization, autogenous bone, and e-PTFE membrane for the treatment of periimplantitis: preliminary results. Int J Oral Maxillofac Implants.2000 15:374-82.

Hamblin, MR, Hasan, T . Photodynamic therapy: a new antimicrobial approach to infectious disease. Photochemistry photobiology; 2004;3:436-50.

Haukioja A, Söderling E, Tenovuo J. Acid production from sugars and sugar alcohols by probiotic lactobacilli and bifidobacteria in vitro. Caries Res. 2008;42(6):449-53.

Haukvik T, Bruzell E, Kristensen S, Tønnesen HH.Photokilling of bacteria by curcumin in different aqueous preparations. Studies on curcumin and curcuminoids XXXVII. Pharmazie. 2009;64(10):666-73.

Hildebrandt GH, Bretz WA. Comparison of culture media and chairside assays for enumerating mutans streptococci. J Appl Microbiol. 2006;100(6):1339-47.

Hope CK, Wilson M. Induction of lethal photosensitization in biofilms using a confocal scanning laser as the excitation source. J Antimicrob Chemother. 2006;57(6):1227-30.

Jenkinson HF, Lamont RJ. Oral microbial communities in sickness and in health. Trends Microbiol .2005;13:589-55.

Jori G, Brown SB. Photosensitized inactivation of microorganisms. Photoche Photobiol Sci 2004;3(5): 403-05.

Junqueira JC, Martins Jda S, Faria RL, Colombo CE, Jorge AO.Photodynamic therapy for the treatment of buccal candidiasis in rats. Lasers Med Sci. 2009;24(6):877-84.

Kelleher K, Thews O, Scherz A, Salomon Y, Vaupel P. Combined hyperthermia and chlorophyll-based photodynamic therapy: tumour growth and metabolic microenvironment British Journal of Cancer.2003; 89: 2333-39.

Kennedy JC, Pottier RH. Endogenous protoporphyrin IX, a clinical useful photosensitizer foi photodynamic therapy. J. Photobiol. B. 1992;14:275-92.

Kepner RL,. Pratt JR. Use of Fluorochromes for Direct Enumeration of Total Bacteria in Environmental Samples: Past and Present. Microbiological Reviews.1994;58(4):603-15.

Klock,B, Krasse B. A comparison between different methods for prediction of caries actinity. Scand. J. Dent. Res.1979;87:129-39.

Köhler B, Petersson BM, Bratthall D. Streptococcus mutans in plaque and saliva and developmentof caries. Scand. J. Dent. Res.1981;89.19-25.

Kolenbrander PE. Oral microbial communities: biofilms, interactions, and genetic 
systems. Annu Rev Microbiol. 200;54: 413-37.

Kolenbrander PE, Palmer RJ, Rickard AH, Jakubovics NS, Chalmers NI, Diaz PI. Bacterial interactions and successions during plaque development. Periodontol. 2006; 42:47-79.

Komerik N , MacRobert AJ Photodynamic therapy as an alternative antimicrobial modality for oral infections.Journal of environmental pathology, toxicology and oncology : official organ of the International Society for Environmental Toxicology and Cancer.2006;25(1-2):487-504.

Konopka K , Goslinski T. Photodynamic Therapy in Dentistry. J Dent Res. 2007;86(8):694-07.

Krosl G, Korbelik M, Dougherty GJ. Induction of immune cell infiltration into murine SCCVII tumour by Photofrin-based photodynamic therapy. $\mathrm{Br} J$ Cancer.1995;71:549-55.

Kumar JV, Green EL. Oral health disparities in New York State. N Y State Dent J.2005;71(7):43-7.

Lee CF, Lee CJ, Chen CT, Huang CT. delta-Aminolaevulinic acid mediated photodynamic antimicrobial chemotherapy on Pseudomonas aeruginosa planktonic and biofilm cultures. J Photochem Photobiol B.2004;19:75(1-2):21-5.

Levy JG. Photodynamic therapy. Trends in Biotechnol.1995;13:14.

Lewis K. Riddle of biofilm resistance. Antimicrob Agents Chemother.2001:45:99907.

Li WT, Tsao HW, Chen,YY Chenga SW, Hsua,YC. A study on the photodynamic properties of chlorophyll derivatives using human hepatocellular carcinoma cells Photochem. Photobiol. Sci., 2007;6:1341-48.

Lima, JMP, Melo, MAS ,Borges, FMC, Teixeira, A. ; Steiner-oliveira C ; Nobredos-santos M, Rodrigues LKA, Zanin ICJ . Evaluation of the antimicrobial effect of photodynamic antimicrobial therapy in an in situ model of dentine caries. European Journal of Oral Sciences,.2009;117: 1-7.

Löe H, Silness J. Periodontal disease in pregnancy I. Prevalence and severity. Acta Odontol Scandinav.1963;21:531-51.

Lui H, Bissonnete R. Photodynamic therapy. In: Goldman MP, Fitz patrich RE., ed. Cutaneous Laser Surgery, ํo edição Saint Louis, Mosby.1999; 437-58.

Machado, AEH. Terapia fotodinâmica: princípios, potencial de aplicação e perspectivas. Quím. Nova. 2000;23(2). 1-7.

Mah TC, O'Toole GA. Mechanisms of biofilms resistance to antimicrobial agents. Trends Microbiol;2001;9(1):34-9. 
Maisch T. Anti-microbial photodynamic therapy: useful in the future? Lasers Med Sci. 2007;22(2):83-91. Epub 2006 Nov 21.

Maisch T, Wagner J, Papastamou V, Nerl HJ, Hiller KA, Szeimies RM, Schmalz G. Combination of $10 \%$ EDTA, Photosan, and a blue light hand-held photopolymerizer to inactivate leading oral bacteria in dentistry in vitro. J Appl Microbiol. 2009;107(5):1569-78.

Marcotte $\mathrm{H}$, Lavoie MC. Oral microbial ecology and the hole of salivary immunoglobulin A; Microbiol Mol Biol Rev.1998;62(1):71-109.

Matthijs S, Adriaems PA. Chlorhexidine varnishes: a review.J Clin Periodontol.2002;29(1):1-8.

Marsh PD, Bradshaw DJ. Dental plaque as a biofilm. J Ind Microbiol.2005;15:16975.

Marthy HJ, Murasecco-Suardi P, Oliveros E, Braun AM. Primary effects os singlet oxygen sensitizers on eggs and embryos of sea urchins. J. Photochem. Photobiol. B.1990;7:303-12.

McBain AJ, Bartolo RG, Catrenich CE, Charbonneau D, Ledder RG, Gilbert P.Effects of a chlorhexidine gluconate-containing mouthwash on the vitality and antimicrobial susceptibility of in vitro oral bacterial ecosystems. Appl Environ Microbiol. 2003;69(8):4770-6.

McFeters GA, Singh A, Byun S, Callis PR, Williams S. Acridine orange staining reaction as an index of physiological activity in Escherichia coli Journal of Microbiological Methods,1991;13(2):87-97.

Metcalf D, Robinson C, Devine D, Wood S.Enhancement of erythrosine-mediated photodynamic therapy of Streptococcus mutans biofilms by light fractionation. $J$ Antimicrob Chemother. 2006;58(1):190-2.

Meyer DH, Fives-Taylor PM. Oral pathogens: from dental plaque to cardiac disease. Curr Opin Microbiol.1998;1:88-95.

Mima EG, Pavarina AC, Dovigo LN, Vergani CE, Costa CA, Kurachi C, Bagnato VS. Susceptibility of Candida albicans to photodynamic therapy in a murine model of oral candidosis. Oral Surg Oral Med Oral Pathol Oral Radiol Endod. 2010;109(3):392-01.

Monfrecola G, Procaccini EM, Bevilacqua M, Manco A, Calabro G, Santoianni P.In vitro effect of 5-aminolaevulinic acid plus visible light on Candida albicans. Photochem Photobiol Sci.2004;3:419-22.

Motisuki C, Lima LM, Spolidorio DM, Santos-Pinto L. Influence of sample type and collection method on Streptococcus mutans and Lactobacillus spp. Counts in the oral cavity. Arch Oral Biol. $2005 ; 50(3): 341-5$. 
Müller P, Guggenheim B, Schmidlin PR. Efficacy of gasiform ozone and photodynamic therapy on a multispecies oral biofilm in vitro. Eur $\mathrm{J}$ Oral Sci. 2007;115(1):77-80.

Nelson JS, McCullough JL, Berns MW. Principles and applications of phododynamic therapy in dermatology. In: Ardnt KA, Dover JS, Olbright SM. Laser ins Cutaneous and Aesthetic Surgery, Philadelphia, LippincottRaven.1997;349-82.

Nyvad B, Kilian M. Microbiology of the early colonization of human enamel and root surfaces in vivo. Scand J Dent Res.1987;95(5):369-80.

Nowis D, Stoklosa T, Legat M, Issat T, Jakobisiak M, Golab J. The influence of photodynamic therapy on the immune response. Photodiagn Photodyn Ther.2005;2:283-98.

Odds FC. Candida and candidosis, a review and bibliography. $2^{\text {nd }}$ edition, Bailiere Tindall, London, 1988.

Oleinick NL, Morris RL, Belichenko I. The role of apoptosis in response to photodynamic therapy: what, where, why and how. Photochem Photobiol Sci.2002;1:1-21.

Oliveira RR, Schwartz-Filho HO, Novaes AB, Garlet GP, de Souza RF, Taba M, Scombatti de Souza SL, Ribeiro FJ. Antimicrobial photodynamic therapy in the non-surgical treatment of aggressive periodontitis: cytokine profile in gingival crevicular fluid, preliminary results. J Periodontol. 2009;80(1):98-105.

O'Neill JF, Hope CK, Wilson M. Oral bacteria in multi-species biofilms can be killed by red light in the presence of toluidine blue. Lasers Surg Med.2002;31:8690.

Pan PC, Harper S, Ricci-Nittel D, Lux R, Shi W. In-vitro evidence for efficacy of antimicrobial mouthrinses. J Dent. 2010, 38 (Si) S16-20.

Paraskevas S. Randomized controlled clinical trials on agents used for chemical plaquecontrol. Int J Dent Hyg. 2005;3(4):162-78.

Park YJ, Lee WY, Hahn BS, Han MJ, Yang WI, Kim BS. Chlorophyll derivatives--a new photosensitizer for photodynamic therapy of cancer in mice. Yonsei Med $\mathrm{J}$. 1989;30(3):212-8.

Pasyechnikova N, Zborovskaya O, Kustrin $\mathrm{T}$. In vitro photodynamic properties of methylene blue in a combination with laser illumination at $630 \mathrm{~nm}$ concerning Candida albicans. Klin Oczna. 2009;111(1-3):15-7.

Paulino TP , Ribeiro KF,. Thedei G , Tedesco AC, Ciancaglini P. Use of hand held photopolymerizer to photoinactivate Streptococcus mutans, Arch. Oral Biol.2004;50:355-61. 
Pinheiro SL, Schenka AA, Neto AA, de Souza CP, Rodriguez HM, Ribeiro MC. Photodynamic therapy in endodontic treatment of deciduous teeth. Lasers Med Sci. 2009;24(4):521-6. Epub 2008 Apr 22.

Rapposch, S., Zangerl, P. and Ginzinger, W. Influence of fluorescence of bacteria stained with acridine orange on the enumeration of microorganisms in raw milk. Journal of Dairy Science.2003; 83: 2753-58.

Prates AC ,Renato A, , Massayoshi A Y Jr. , Suzuki LC, Hashimoto MCE , Cai S , Soares SG, et al. Bactericidal effect of malachite green and red laser on Actinobacillus actinomycetemcomitans Journal of Photochemistry and Photobiology B: Biology 86 .2007;70-76.

Pratten J, Barnett P, Wilson M.Composition and susceptibility to chlorhexidine of multispecies biofilms of oral bacteria. Appl Environ Microbiol. 1998 Sep;64(9):3515-9.

Piovano S, Marcantoni M, Dono R, Bellagamba $\mathrm{H}$. Effect of a chlorhexidine varnish on Streptococcus mutans in saliva. Acta Odontol Latinoam.2005; 18(1):713.

Raab O. Z. Biol.1900;39:524.

Raad, I., H. Hanna, T. Dvorak, G. Chaiban, and R. Hachem. Optimal antimicrobial catheter lock solution using different combinations of minocycline, EDTA, and 25 percent ethanol rapidly eradicates organisms embedded in biofilm. Antimicrob. Agents Chemother.2007; 51:78-83.

Roberts DJH, Cairduff F. Photodynamic therapy: therapy of primary skin cancer: a review. Br. J. Plast. Surg.1995;48:360-70.

Rosa OPS, Rocha RSS. Clorexidina e a cárie dentária. Cecade News. $1993 ; 1(1 / 2): 1-24$.

Rovaldi,CR , Pievsky A, Sole NA, Friden PM, Rothstein DM, Spacciapoll P. Photoactive Porphyrin Derivative with Broad-Spectrum Activity against Oral Pathogens In Vitro. antimicrobial agents and chemotherapy.2000;44(12):3364-67.

Sarkar S, Wilson M . Lethal photosensitization of bacteria in subgingival plaque from patients with chronic periodontitis. J Periodontal Res.1993;28:204-10.

Sbarra MS, Arciola CR, Di Poto A, Saino E, Rohde H, Speziale P, Visai L. The photodynamic effect of tetra-substituted N-methyl-pyridyl-porphine combined with the action of vancomycin or host defense mechanisms disrupts Staphylococcus epidermidis biofilms. Int J Artif Organs. 2009;32(9):574-83.

Sharma M, Visai L, Bragheri F, Cristiani I, Gupta PK, Speziale P. Toluidine bluemediated photodynamic effects on staphylococcal biofilms. Antimicrob Agents Chemother. 2008;52(1):299-05. Epub 2007 Oct 29. 
Seal GJ, Ng YL, Spratt D, Bhatti M, Gulabivala K. An in vitro comparison of the bactericidal efficacy of lethal photosensitization or sodium hypochlorite irrigation on Streptococcus intermedius biofilms in root canals. Int Endod J.2002;35:268-74.

Sharma M, Visai L, Bragheri F, Cristiani I , Kumar GP, Speziale P. Toluidine Blue-Mediated Photodynamic Effects on Staphylococcal Biofilms_ antimicrobial agents and chemotherapy.2008;52(1):299-05.

Sharman WM, Van Lier JE, Allen CM. Targeted photodynamic therapy via receptor mediated delivery systems. Adv Drug Deliv Rev.2004;56:53-76.

Simplício Fl, Maionchi $\mathrm{F}$, Hioka N. Nova . terapia fotodinâmica: aspectos farmacológicos, aplicações e avanços recentes nodesenvolvimento de medicamentos.2002;25(5):801-07.

Soares RRS. Estudo das propriedades da Clorofila a e da Feofitina a visando a Terapia Fotodinamica. Dissertação de mestrado apresentada a Universidade Estadual de Maringá, 2006.

Solban N, Rizvi I, Hasan T. Targeted photodynamic therapy. Lasers Surg Med.2005:38:522-31.

Soukos NS, Mulholland SE, Socransky SS, Doukas AG. Photodestruction of human dental plaque bacteria: enhancement of the photodynamic effect by photomechanical waves in an oral biofilm model. Lasers Surg Med. 2003;33(3):161-8.

Soukos NS, Chen PS, Morris JT, Ruggiero K, Abernethy AD, Som S, Foschi F, Doucette S, Bammann LL, Fontana CR, Doukas AG, Stashenko PP Photodynamic therapy for endodontic disinfection. J Endod. 2006;32(10):979-84 .

Southern EN, McCombs GB, Tolle SL, Marinak K. The comparative effects of $0.12 \%$ chlorhexidine and herbal oral rinse on dental plaque-induced gingivitis. $\mathrm{J}$ Dent Hyg. 2006;80(1):12.

Soet JJ, Gruythuysen RJ, Bosch JA, van Amerongen WE. The effect of 6mounthly application of $40 \%$ chlorhexidine varnish on the microflora and dental caries incidence in a population of children in Surinam. Caries Res.2002;36(6):449-55.

Souza RC ,Junqueira JC, Rossoni RD, Pereira CA, Munin E, Jorge AOC. Comparison of the photodynamic fungicidal efficacy of methylene blue, toluidine blue, malachite green and low-power laser irradiation alone against Candida albicans Lasers Med Sci 2010;25(3):385-9.

Spratt DA, Pratten J. Biofilms and the oral cavity. Re/Views Environ Sci Bio Technol.2003;2:109-20.

Stemberg ED, Dolphin D, Brückner C. Tetrahedron. Porphyrin-based photosensitizers for use in photodynamic therapy; 1998;54:4151. 
Street CN, Pedigo LA, Loebel NG. Energy dose parameters affect antimicrobial photodynamic therapy-mediated eradication of periopathogenic biofilm and planktonic cultures. Photomed Laser Surg. 2010;28 Suppl 1:S61-6.

Streit NM, Canterle LP, Canto MW, Hecktheuer LHH. The Chlorophylls. Ciência Rural, Santa Maria.2005;35(3)p.748-55.

Sutherland IW . Biofilm exopolysaccharides: a strong and sticky framework. Microbiology.2001;147:3-9.

Svanberg M, Krasse B. Comparative recovery of mutans Stretococci on two selective media. Caries Res.1990;24:36-38.

Takahashi N,Nyvad B. Caries Ecology Revisited: Microbial Dynamics and the Caries Process.2008;42:409-18.

Takahashi N, Nyvad B. The Role of Bacteria in the Caries Process: Ecological Perspectives. J Dent Res. 2010

Takenaka, S., H. M. Trivedi, A. Corbin, B. Pitts, and P. S. Stewart. Direct visualization of spatial and temporal patterns of antimicrobial action within model oral biofilms. Appl. Environ. Microbiol.2008;74:1869-75.

Teles RP, Teles FR. Antimicrobial agents used in the control of periodontal biofilms: effective adjuncts to mechanical plaque control? Braz Oral Res. 2009;23 Suppl 1:39-48.

Tomás I, Cousido MC, Tomás M, Limeres J, García-Caballero L, Diz P. In vivo bactericidal effect of $0.2 \%$ chlorhexidine but not $0.12 \%$ on salivary obligate anaerobes.'Arch Oral Biol. 2008;53(12):1186-91.

Thylstrup A, Fejerskov O. O ambiente oral - uma introdução. In: Thylstrup A, Fejerskov O. Cariologia clínica. São Paulo: Santos.995;13-16.

Torezan LAR. Avaliação da Eficácia da Terapia Fotodinâmica com Ácido 5-Delta aminolevulínico (ALA) Tópico no Carcinoma Basocelular. Dissertação apresentada a Faculdade de Medicina da USP para obtenção do Título de mestre em Medicina. 2000.

Tromberg BJ, Oresteinm A, Kimel S, Barker SJ, hyatt J, Nelson JS, Berns MW. In vivo tumor oxygen tension measurements for the evaluation of the efficiency of photodynamic therapy. Photochem. Photobiol.1990;52:.375-85.

Ullbro C, Brown A, Twetman S. Preventive periodontal regimen in PapillonLefevre syndrome. Pediatr Dent. 2005;27(3):226-32.

Urashima M, Hoshi Y, Akatsuka J. Analysis of leukemic cell activity with a simple acridine orange staining method. Int J Hematol. 1992;56(3):197-204. 
Usacheva MN, Teichert MC, Biel MA. Comparison of the methylene blue and toluidine blue photobactericidal efficacy against gram-positive and gram-negative microorganisms. Lasers Surg Med. 2001;29(2):165-73.

Usacheva MN, Matthew C. Teichert, BA, Chet E, Sievert BS, ,Merrill A. Biel MD. Effect of Ca2p on the Photobactericidal Efficacy of Methylene Blue and Toluidine Blue Against Gram-Negative Bacteria and the Dye Affinity for Lipopolysaccharides Lasers in Surgery and Medicine.2006;38:946-54.

Usuda J., Chiu S, Azizuddin K, Xue L, Lam M, Nieminen AL, Oleinick NL. Promotion of Photodynamic Therapy-Induced Apoptosis by the Mitochondrial Protein Smac/DIABLO: Dependence on Bax Photochemistry and Photobiology.2002;2:217-23.

Van der meulen FW, Ibrahim K, Sterenborg HJCM, Alphen VL, Maikoe A, Dankert $\mathrm{J}$. Porphyrin-based photosensitizers for use in photodynamic therapy $\mathrm{J}$. Photochem. Photobiol. B40, 204, 1997.

Van Strydonck DA, Timmerman MF, Van der Velden U, Van der Weijden GA. Plaque inhibition of two commercially available chlorhexidine mouthrinses. J Clin Periodontol.2005;32(3):305-9.

Van Houte J, Lopman J, Kent R. The final $\mathrm{pH}$ of bacteria comprising the predominant flora on sound and carious human root and enamel surfaces.

J Dent Res. 1996;75(4):1008-14.

Von Ohle C, Gieseke A, Nistico L, Decker EM, DeBeer D, Stoodley P. Real-time microsensor measurement of local metabolic activities in ex vivo dental biofilms exposed to sucrose and treated with chlorhexidine. Appl Environ Microbiol. 2010;76(7):2326-34.

Von Tappeiner. Muench. Med. Wochenschr.1903;47: 2024.

Vrounraets MB, Visser GW, Snow GB, Van Dongen GA. Basic principles, applications in oncology and improved selectivity of photodynamic therapy. Anticancer Res.2003;23:505-22.

Watnick P, Kolter R. Biofilm, city of microbes. J Bacteriol.2000;182(10): 2675-9.

Wainwright $M$. Photodynamic antimicrobial chemotherapy (PACT). Photodynamic antimicrobial chemotherapy (PACT). JAntimicrob Chemother.1998; 42:13-28.

Wainwright M, Crossley KB. Photosensitizing agents-circumventing resistance and breaking down biofilms: a review. Int Biodeterior Biodegrad.2004;53:119-26. 
Weinberger S J; Wright G Z Correlating Streptococcus mutans with dental caries in young children using a clinically applicable microbiological method. Caries research 1989;23(5):385-8.

Weinstein GD, McCullough, Nelson JS, Berns MW. Low dose Photofrin II photodynamic therapy of psoriasis. J Invest Dermatol.1991;96: 573.

Williams JA, Pearson GJ, Colles MJ, Wilson M.The effect of variable energy input from a novel light source on the photoactivated bactericidal action of toluidine blue O on Streptococcus Mutans. Caries Res. 2003;37(3):190-3.

Williams JA, Pearson GJ, Colles MJ, Wilson M. The photo-activated antibacterial action of toluidine blue $\mathrm{O}$ in a collagen matrix and in carious dentine. Caries Res. 2004;38(6):530-6.

Williams JA, Pearson GJ, Colles MJ. Antibacterial action of photoactivated disinfection $\{P A D\}$ used on endodontic bacteria in planktonic suspension and in artificial and human root canals. J Dent.2006;34:363-71.

Wilson M, Burn T, Pratten J, Pearson GJ. Bacteria in supragingival plaque samples can be killed by low-power laser light in the presence of a photosensitizer. J. Appl. Bacteriol. 1995;78(5).569-74.

Wilson M, Burns T, Pratten J. Killing of Streptococcus sanguis in biofilms using a light-activated antimicrobial agent. J Antimicrobial Chemother.1996 37(2): 377-81.

Wilson M. Lethal photosensitization of oral bacteria and its potential application in the photodynamic therapy or oral infections. Photochem. Photobiol.2004;3:412-8.

Winckler KD. Special section: focus on anti-microbial photodynamic therapy (PDT). J Photochem Photobiol B. 2007;3;86(1):43-4.

Wolf P, Finkk-Puches R, Cerroni L, Kerl H. Photodynamic Therapy for Mycosis Fungoides J. Am. Acad. Derm.1994;31: 678.

Wong TW, Wang YY, Sheu HM,Chuang YC. Bactericidal Effects of Toluidine Blue-Mediated Photodynamic Action on Vibrio vulnificus antimicrobial agents and chemotherapy.2005:49(3)895-02.

Wong RW, Hägg U, Samaranayake L, Yuen MK, Seneviratne CJ, Kao R.

Antimicrobial activity of Chinese medicine herbs against common bacteria in oral biofilm. A pilot study. Int J Oral Maxillofac Surg. 2010; 39(6):599-605.

Wood S, Nattress B, Kirkham J, Shore R, Brookes S, Griffiths J, et al. An in vitro study of the use of photodynamic therapy for the treatment of natural oral plaque biofilms formed in vivo. J Photochem Photobiol B.1999:;50:1-7.

Wood S, Metcalf D, Devine D, Robinson C. Erythrosine is a potential photosensitizer for the photodynamic therapy of oral plaque biofilms. J Antimicrob Chemother. 2006;57(4):680-4. 
Zanatta FB, Kuchenbecker C. Chlorhexidine: action's mechanisms and recent evidences of it/s efficacy over supragingival biofilm context. Scientific-A 2007;1(2):35-43.

Zanin IC, Gonçalves RB, Junior AB, Hope CK, Pratten J. Susceptibility of Streptococcus mutans biofilms to photodynamic therapy: an in vitro study. J Antimicrob Chemother.2005;24:330.

Zanin IC, Lobo MM, Rodrigues LK, Pimenta LA, Höfling JF, Gonçalves RB. Photosensitization of in vitro biofilms by toluidine blue $\mathrm{O}$ combined with a lightemitting diode. Eur J Oral Sci. 2006;114(1):64-9.

Zeina,B J.GREENMAN, ${ }^{*}$ W.M.PURCELL* AND B.DAS Killing of cutaneous microbial species by photodynamic therapy. British Journal of Dermatology. 2001;144:274-78.

Zijnge V, van Leeuwen MB, Degener JE, Abbas F, Thurnheer T, Gmür R, Harmsen HJ. Oral biofilm architecture on natural teeth. PLoS One. 2010;5(2):e9321. 

Anexos 





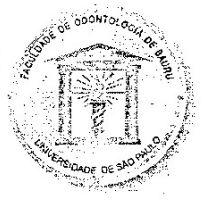

Processo $n \div 144 / 2008$

Bauru, 06 de julho de 2009

\section{Universidade de São Paulo \\ Faculdade de Odontologia de Bauru}

Al. Dr. Octávio Pinheiro Brisolla, 9-75--Bauru-SP - CEP 17012-901 - C.P. 73

PABX (0XX14)3235-8000 - FAX (0XX14)3223-4679

Comitê de Ética em Pesquisa (14)323j-8356

mferrari@fob.usp.br

Senhora Professora,

Informamos que após o envio da documentação solicitada referente ao projeto de pescuisa encaminhado a este Comitê de Ética em Pesquisa "Ação da terapia fotodinâmica sobre o biofilme dentário humano", de autoria de vanessa Tessarolli, foi novamente analisado e considerado APROVADO por este Colegiado, em reunião realizada no dia 24 de junho de 2009.

Solicitamos que qualquer alteração efetuada no referido projeto de pesquisa seja comunicada a este Colegiado, bem como ao término do trabalho, nos envie o relatório final com os Termos de Consentimento Livre e Esclarecido devidamente assinados pelos sujeitos da pesquisa, para novo parecer, o qual será utilizado para pubíicação cientifica.

Atenciosamente,

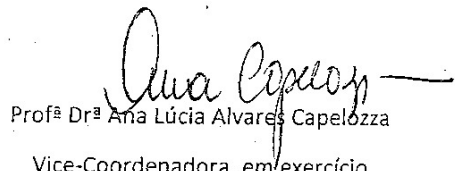

Profe Driq Maria Aparecida de Andrade Moreira Machado

Docente do Departamento de Odontopediatria, Ortodontia a Saude Coletiva 


\section{Universidade de São Paulo Faculdade de Odontologia de Bauru}

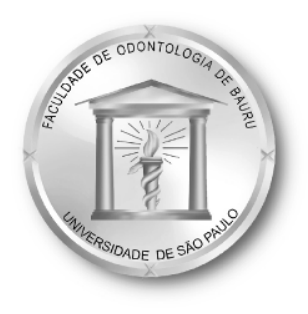

\section{TERMO DE CONSENTIMENTO LIVRE E ESCLARECIDO}

\section{1 - Título do Trabalho Experimental}

Ação da Terapia Fotodinâmica sobre biofilme dentário humano

\section{2 - Objetivo}

Esta pesquisa tem por objetivo avaliar o potencial antimicrobiano dos corantes clorofila líquida e TBO na terapia fotodinâmica contra o biofilme dentário humano.

\section{3 - Procedimentos da Fase Experimental}

Nesta pesquisa você terá que usar um aparelho bucal com 7 blocos de dentes bovinos estéreis, disposto em duas fileiras com 3 blocos em cada, durante 14 dias.

Você utilizará o dispositivo o dia todo $(24 \mathrm{~h} /$ dia) exceto durante as refeições (3 refeições diárias de $1 \mathrm{~h}$ ), sendo que nestes períodos os dispositivos serão mantidos em um estojo plástico, envolto em gaze umedecida em água. Será permitido realizar a higiene bucal normalmente após as refeições, sem o dispositivo. Será permitido também limpar o aparelho com escova dental, sendo proibida a escovação da área que contiver os dentes. Você não deverá ingerir bebidas, exceto água, durante o experimento, a não ser nos horários das refeições quando não estiver utilizando o aparelho.

Oito vezes ao dia, você deverá gotejar uma solução de sacarose a $20 \%$ (que será fornecida e trocada a cada dois dias) sobre todos os dentes e após 5 minutos recolocar 0 dispositivo na boca.

Você receberá o dentifrício a ser usado, a solução de sacarose, uma caixa plástica para armazenagem do dispositivo durante as refeições.

\section{4 - Benefício para participar do experimento}

Você receberá uma limpeza profissional dos dentes.

Fica claro que você pode, a qualquer momento, retirar seu CONSENTIMENTO LIVRE E ESCLARECIDO e deixar de participar dessa pesquisa. Todo o trabalho realizado e as informações obtidas é confidencial e será guardada por força do sigilo profissional (Art. 9ํㅜㅇ do Código de Ética Odontológica).

Qualquer dúvida ou maiores esclarecimentos você poderá recorrer o autor do projeto - Vanessa Tessarolli - Telefone (14) 81292533. Caso queira apresentar reclamações em relação a sua participação na pesquisa, poderá entrar em contato com o Comitê de Ética em Pesquisa em Seres Humanos, da FOB-USP, pelo endereço da Al. Dr. Octávio Pinheiro Brisolla, 9-75 (sala no prédio da Biblioteca, FOB/USP) ou pelo telefone (14)3235-8356. 
